\title{
EXTRAÇÕES DE NUTRIENTES PELO MELOEIRO RENDILHADO CULTIVADO EM AMBIENTE PROTEGIDO COM A ADIÇÃO DE POTÁSSIO E $\mathrm{CO}_{2}$ NA ÁGUA DE IRRIGAÇÃO
}

\author{
CRISTIAINI KANO
}

Dissertação apresentada à Escola Superior de

Agricultura "Luiz de Queiroz", Universidade de São Paulo, para obtenção do título de Mestre em Agronomia, Área de Concentração: Solos e Nutrição de Plantas.

PIRACICABA

Estado de São Paulo - Brasil

Julho -2002 


\section{EXTRAÇÕES DE NUTRIENTES PELO MELOEIRO RENDILHADO CULTIVADO EM AMBIENTE PROTEGIDO COM A ADIÇÃO DE POTÁSSIO E $\mathrm{CO}_{2}$ NA ÁGUA DE IRRIGAÇÃO}

\section{CRISTIAINI KANO}

Engenheiro Agrônomo

Orientador: Prof. Dr. QUIRINO AUGUSTO DE CAMARGO CARMELLO

Dissertação apresentada à Escola Superior de Agricultura "Luiz de Queiroz", Universidade de São Paulo, para obtenção do título de Mestre em Agronomia, Área de Concentração: Solos e Nutrição de Plantas.

PIRACICABA

Estado de São Paulo - Brasil

Julho -2002 


\title{
Dados Internacionais de Catalogação na Publicação (CIP) DIVISÃO DE BIBLIOTECA E DOCUMENTAÇÃO - ESALQ/USP
}

\author{
Kano, Cristiaini \\ Extrações de nutrientes pelo meloeiro rendilhado cultivado em ambiente protegido \\ com a adição de potássio e $\mathrm{CO}_{2}$ na água de irrigação / Cristiaini Kano. - - Piracicaba, \\ 2002. \\ $102 \mathrm{p}$. \\ Dissertação (mestrado) - - Escola Superior de Agricultura Luiz de Queiroz, 2002. \\ Bibliografia. \\ 1. Água de irrigação 2. Dióxido de carbono 3. Fertirrigação 4. Melão 5. \\ Nutriente 6. Potássio I. Título
}

CDD 635.61 
Aos meus pais e aos meus irmãos

pelo amor, carinho, felicidade e força

\section{agradeco E DEDICO}




\section{AGRADECIMENTOS}

À Deus, por iluminar o meu caminho nos momentos da vida.

Ao Prof. Dr. Quirino Augusto de Camargo Carmello pela orientação, amizade, paciência e atenção, durante todo o período para realização deste trabalho.

Ao Prof. Dr. José Antônio Frizzone pela oportunidade em desenvolver este trabalho, pela amizade, paciência e atenção.

Ao Departamento de Solos e Nutrição de Plantas pela oportunidade de realização do curso de mestrado.

À Coordenação de Aperfeiçoamento de Pessoal de Nível Superior (CAPES) pela concessão da bolsa.

À doutoranda Silvana da Silva Cardoso pela amizade e convívio durante a condução do experimento.

Ao grupo de práticas em irrigação e drenagem (GPID) e ao aluno Tiago pela amizade e colaboração na condução das plantas quando possível.

Às funcionárias Edinéia, Lúcia, Lurdes, Nivanda e Sueli do Setor de Nutrição Mineral de Plantas da USP/ESALQ pela amizade e auxílio nas análises químicas e ao Sr. Antônio do Departamento de Engenharia Rural. 
Aos pesquisadores Gilmar Ribeiro Nachtigall e Valdemício Ferreira de Sousa pelas valiosas sugestões.

Às amigas de graduação que pude reencontrá-las e a amiga Sueli Suemi pela amizade e força.

Aos novos amigos e colegas pela amizade e por qualquer tipo de apoio durante esse período.

Aos professores de graduação que me incentivaram durante a etapa anterior de minha vida.

A todos que direta ou indiretamente contribuíram para a realização deste trabalho. 


\section{SUMÁRIO}

\begin{tabular}{|c|c|}
\hline RESUMO & vi \\
\hline SUMMARY ................................ & viii \\
\hline 1 INTRODUÇÃO & 1 \\
\hline 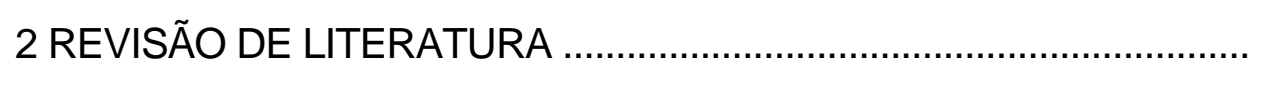 & 3 \\
\hline 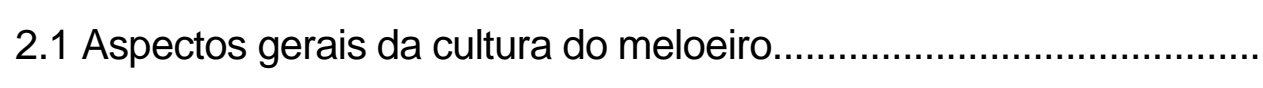 & 3 \\
\hline 2.2 Extração de nutrientes pelo meloeiro...................... & 6 \\
\hline 2.3 Utilização de potássio na cultura do meloeiro.................... & 9 \\
\hline 2.4 Utilização de dióxido de carbono $\left(\mathrm{CO}_{2}\right)$ na água de irrigação......... & 12 \\
\hline 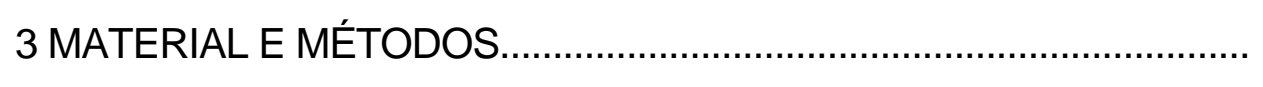 & 18 \\
\hline 3.1 Localização e características da área experimental........................... & 18 \\
\hline 3.2 Delineamento experimental e tratamentos.... & 18 \\
\hline 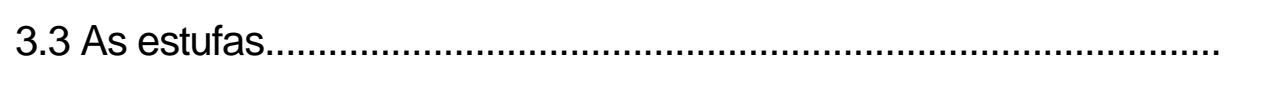 & 19 \\
\hline 3.3.1 Características do solo dos canteiros... & 20 \\
\hline 3.3.2 Calagem e adubação de plantio.............. & 21 \\
\hline 3.4 Condução das plantas.......... & 22 \\
\hline 3.4.1 Mudas................................... & 22 \\
\hline 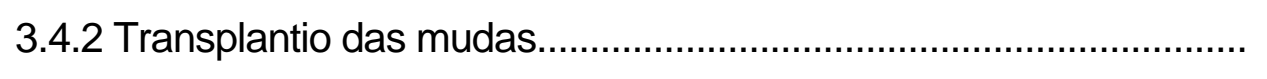 & 22 \\
\hline 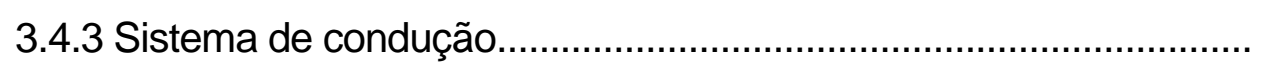 & 23 \\
\hline 3.4.4 Controle fitossanitário........ & 23 \\
\hline 5 Irrigação.................................. & 24 \\
\hline
\end{tabular}


3.6 Fertirrigação, aplicação de potássio e dióxido de carbono $\left(\mathrm{CO}_{2}\right) \ldots \ldots . \quad 25$

3.6.1 O sistema de fertirrigação e aplicação de fertilizantes..................... 25

3.6.2 Aplicação de potássio.................................................................. 26

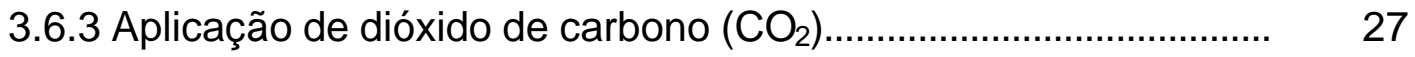

3.7 Obtenção dos resultados............................................................. $\quad 30$

3.7.1 Extração de nutrientes ao longo das épocas avaliadas................. $\quad 30$

3.7.1.1 Coleta das plantas..............................................................

3.7.1.2 Análises químicas das plantas.................................................. 31

3.7.2 Produção de frutos............................................................... 31

3.8 Análise estatística.........................................................................

4 RESULTADOS E DISCUSSÃO......................................................... 33

4.1 Características das plantas coletadas em cada estádio fenológico.... 33 4.2 Produção de frutos ....................................................................

4.3 Extração de nutrientes no sistema convencional................................ 39

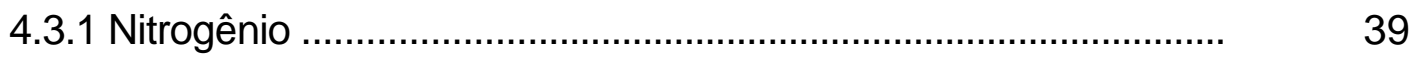

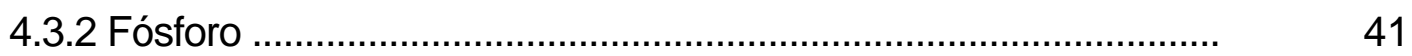

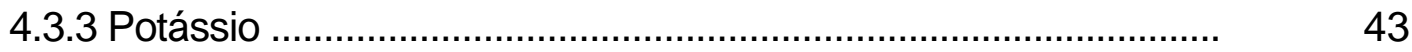

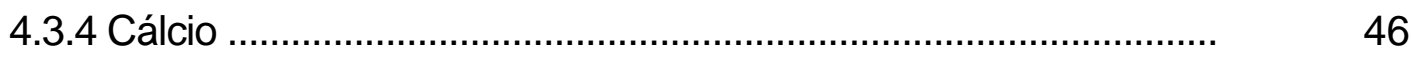

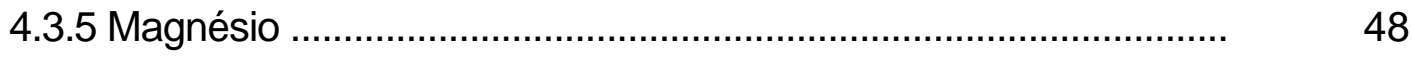

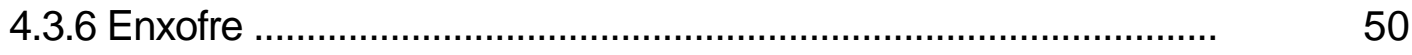

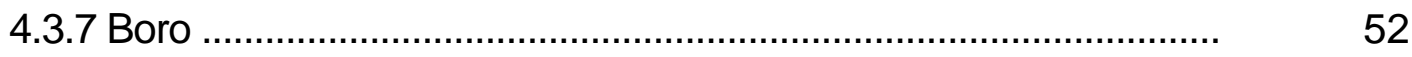

4.3.8 Cobre ..............................................................................

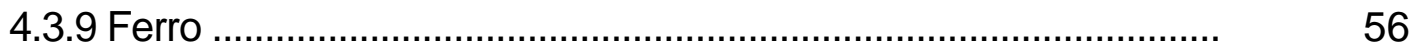

4.3.10 Manganês ........................................................................... 58

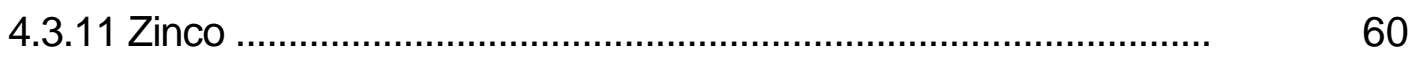

4.4 Extração de nutrientes no sistema convencional com adição de $\mathrm{CO}_{2}$ à água de irrigação....................................................................... 62

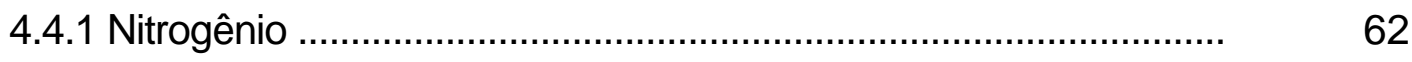

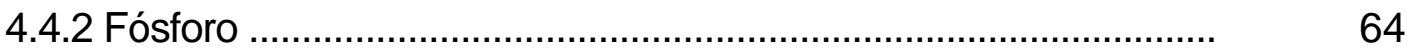

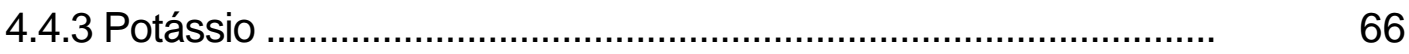




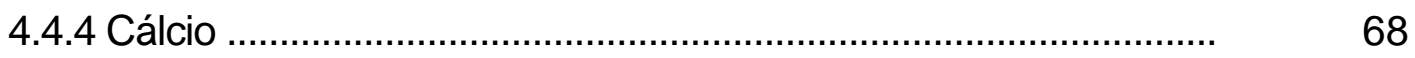

4.4.5 Magnésio ............................................................................

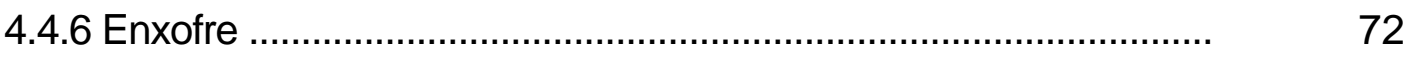

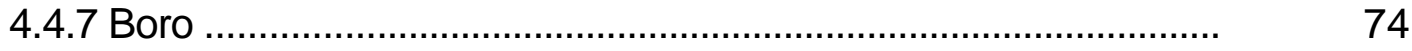

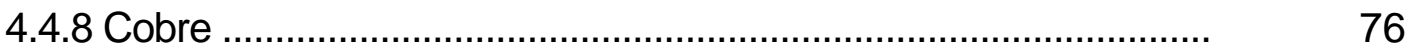

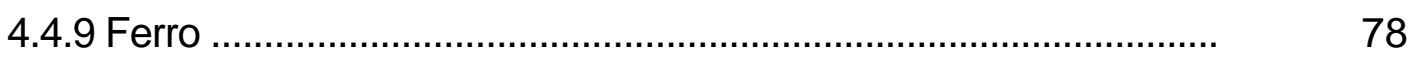

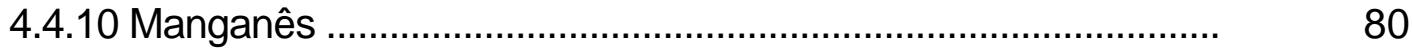

4.4.11 Zinco ........................................................................

4.5 Extração comparativa de nutrientes ................................................ $\quad 84$

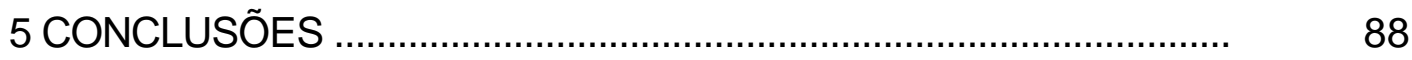

REFERÊNCIAS BIBLIOGRÁFICAS ................................................... 90 


\title{
EXTRAÇÕES DE NUTRIENTES PELO MELOEIRO RENDILHADO CULTIVADO EM AMBIENTE PROTEGIDO COM A ADIÇÃO DE POTÁSSIO E $\mathrm{CO}_{2}$ NA ÁGUA DE IRRIGAÇÃO
}

\author{
Autora: CRISTIAINI KANO \\ Orientador: Prof. Dr. QUIRINO AUGUSTO DE CAMARGO CARMELLO
}

RESUMO

O meloeiro rendilhado (Cucumis melo L. var reticulatus Naud.), por apresentar alto valor comercial, tem sido uma opção de plantio para os produtores de hortaliças. Com o objetivo de avaliar as extrações de nutrientes desse meloeiro cultivado em ambiente protegido, em função de doses de potássio e da utilização de dióxido de carbono $\left(\mathrm{CO}_{2}\right)$ na água de irrigação, (água carbonatada), realizou-se este trabalho no período de setembro a dezembro de 2001 no Departamento de Engenharia Rural da USP/ESALQ, em

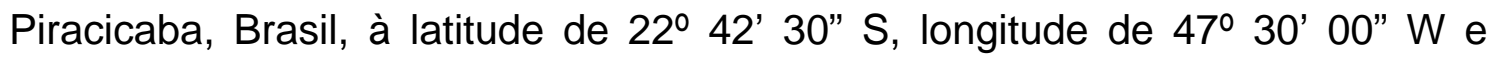
altitude de $580 \mathrm{~m}$. Para isso, foram utilizadas duas estufas, nas quais foram aplicadas quatro doses de potássio $\left(50,150,300\right.$ e $600 \mathrm{~kg} \mathrm{ha}^{-1}$ de $\left.\mathrm{K}_{2} \mathrm{O}\right)$ via sistema de irrigação por gotejamento. Em uma das estufas foi aplicado $301,8 \mathrm{~kg}$ ha $^{-1}$ de $\mathrm{CO}_{2}$ via água de irrigação, porém de forma separada da aplicação de potássio. A outra estufa foi mantida no nível atmosférico de $\mathrm{CO}_{2}$ (condição natural). O delineamento experimental utilizado foi blocos casualizados com quatro repetições. Para obtenção da extração dos nutrientes ao longo dos 
estádios fenológicos, as plantas foram coletadas no dia do transplantio (muda), no desenvolvimento vegetativo, no início do florescimento, no início e meio da frutificação e no período de colheita.

Verificou-se que a dose de $300 \mathrm{~kg} \mathrm{ha}^{-1}$ de $\mathrm{K}_{2} \mathrm{O}$ foi a que proporcionou maior produção de frutos, maior peso médio e comprimento médio dos frutos. $\mathrm{A}$ aplicação de $\mathrm{CO}_{2}$ via água de irrigação proporcionou aumento da ordem de $11 \%$ na produção total de frutos, $20 \%$ na produção comercial e $23 \%$ no número de frutos comerciais. A extração de nutrientes acumulados na parte aérea teve maior incremento entre o início do florescimento e o início da frutificação, independente dos tratamentos. A ordem de extração dos macronutrientes acumulados na parte aérea foi: potássio > nitrogênio > cálcio > magnésio > enxofre > fósforo. A aplicação de $\mathrm{CO}_{2}$ aumentou a extração de zinco, e diminuiu a extração de potássio e magnésio. Para os micronutrientes, a ordem da extração acumulada na parte aérea em ambos os sistemas utilizados foi: ferro > manganês $>$ zinco $>$ cobre $\sim$ boro. As doses de potássio aumentaram a extração desse nutriente acumulado na parte aérea da planta na colheita, e não influenciaram os demais nutrientes. 


\title{
NUTRIENTS EXTRACTIONS BY NET MELON CULTIVATED IN GREENHOUSE WITH POTASSIUM AND $\mathrm{CO}_{2}$ ADDED IN THE WATER IRRIGATION
}

\author{
Author: CRISTIAINI KANO \\ Adviser: Prof. Dr. QUIRINO AUGUSTO DE CAMARGO CARMELLO
}

\section{SUMMARY}

For presenting more commercial value, the net melon (Cucumis melo $\mathrm{L}$. var reticulatus Naud.) has been an option of greenhouse planting for the horticulturists. Aiming to evaluate the nutrients extractions from this melon cultivated in greenhouse in function of potassium rates and by the use of carbon dioxide $\left(\mathrm{CO}_{2}\right)$ in the water irrigation (carbonated water), this work was carried out from September to December 2001, in the experimental area at Agricultural Engineering Department of USP/ESALQ in Piracicaba, Brazil at 22 $42^{\prime} 30^{\prime \prime} \mathrm{S}$ latitude and 47-30' $00^{\prime} \mathrm{W}$ longitude and $580 \mathrm{~m}$ of altitude. Two greenhouses were then used in which were apllied four rates of potassium (50, 150, 300 and $600 \mathrm{~kg} \mathrm{ha}^{-1}$ of $\mathrm{K}_{2} \mathrm{O}$ ) via drip irrigation system. In one of the greenhouse was apllied $301.8 \mathrm{~kg} \mathrm{ha}^{-1}$ of $\mathrm{CO}_{2}$ injected through water irrigation in a separate way from de potassium injection. The other greenhouse was kept in the atmospheric level of $\mathrm{CO}_{2}$ (natural condition). The experiment was conducted in fully randomized blocks, with four replications. To obtain the nutrients extraction through the stages of plant development, the plants were collected in the 
transplant day (seedling), in the vegetative stage, in the beginning of the flowering stage, in the beginning and in the middle of fruit production and in the harvest period.

It was verified that the rate of $300 \mathrm{~kg} \mathrm{ha}^{-1}$ of $\mathrm{K}_{2} \mathrm{O}$ was better to fruits production, to the medium weight and medium height of the fruits. The $\mathrm{CO}_{2}$ injection in the water irrigation increased $11 \%$ the total yield $20 \%$ of commercial yield and $23 \%$ the number of commercial fruits. The greatest increase of nutrient extraction happened between the beginning of the flowering and the beginning of the fruit production being independent of the treatments. The order of macronutrients accumulated in aerial part was: potassium > nitrogen $>$ calcium $>$ magnesium $>$ sulphur $>$ phosphorus. The $\mathrm{CO}_{2}$ injection in the water irrigation increased the zinc extraction and reduced the potassium and magnesium extraction. For the micronutrients in both used systems the order of extraction obtained was: iron $>$ manganese $>$ zinc $>$ copper $\sim$ boron. The potassium rates increased the extraction on this nutrient accumulated in the aerial part of the plant in the harvest and did not influence the other nutrients. 


\section{INTRODUÇÃO}

O cultivo de hortaliças em ambiente protegido vem tornando-se cada vez mais freqüente. Entre as culturas conduzidas nessa condição, destaca-se o meloeiro rendilhado (Cucumis melo var. reticulatus Naud.) que, por apresentar maior valor comercial, como conseqüência de seu aroma e sabor característico, tem sido uma opção de plantio.

Entre os macronutrientes, o potássio é o nutriente que apresenta maior contribuição na qualidade dos frutos. Pela falta de informações sobre a quantidade de potássio a ser aplicado e pelo número de informações deficiente relativas às exigências nutricionais do meloeiro, em especial a esse tipo de melão, caracteriza-se a importância do estudo visando avaliar a resposta do meloeiro a esse nutriente.

Com a predominância da utilização da fertirrigação em ambiente protegido, o conhecimento da extração acumulada de nutrientes, torna-se importante para uma melhor eficiência no fornecimento de nutrientes às plantas, em busca de uma melhor produtividade da cultura. Pela variabilidade das respostas dos diferentes cultivares, quanto à extração de macronutrientes e micronutrientes, bem como pelo limitado conhecimento sobre a extração de nutrientes pelo meloeiro rendilhado, ressalta a importância desse estudo devido ao seu destaque nas condições brasileiras.

A técnica da utilização de dióxido de carbono $\left(\mathrm{CO}_{2}\right)$ na água de irrigação (água carbonatada) é recente no Brasil e vem sendo estudada em várias culturas com sucesso como em hortaliças, em frutíferas e em espécies ornamentais, além de ser uma alternativa para otimização dos equipamentos de 
irrigação já instalados. Pelos resultados de pesquisa tem sido verificado que essa técnica pode aumentar a produtividade de várias culturas e que o seu custo de adoção é pequeno em relação ao custo total de produção, além de promover alterações na absorção de nutrientes em algumas culturas. Contudo, para o meloeiro rendilhado ainda são poucas as informações deste efeito do $\mathrm{CO}_{2}$ para as condições brasileiras.

Com isso, os objetivos deste trabalho foram avaliar a extração de nutrientes nos estádios de desenvolvimento do meloeiro rendilhado cultivado em ambiente protegido em função de doses de potássio e da utilização de $\mathrm{CO}_{2}$ via água de irrigação, bem como determinar a dose de potássio mais adequada nessas condições. 


\section{REVISÃO DE LITERATURA}

\subsection{Aspectos gerais da cultura do meloeiro}

O meloeiro pertence à família Cucurbitaceae, gênero Cucumis e espécie Cucumis melo L. Sua origem ainda não está bem definida, pois alguns autores acreditam que seja da África, enquanto que outros do oeste da Ásia (Mallick \& Masui, 1986; Zapata et al., 1989). Sua introdução no Brasil foi feita pelos imigrantes europeus em meados da década de 60, no Rio Grande do Sul, expandindo-se para o Estado de São Paulo e posteriormente para as regiões Norte e Nordeste, destacando-se, em termos de área plantada e produção, entre as décadas de 80 e 90 (Araujo, 1980; Ferreira et al., 1982; Sousa et al., 1999a).

O plantio de melão está espalhado por todas as regiões do Brasil, sendo que a região Nordeste é a maior produtora de melão do país, com cerca de 95\% do total produzido. Em 2001, o Brasil exportou cerca de 29.000 toneladas, com uma área colhida de aproximadamente 11.000 hectares. Para o melão amarelo, a produtividade esperada é de $25 \mathrm{t} \mathrm{ha}^{-1}$ com uma densidade de 10.000 plantas ha ${ }^{-1}$ no Estado do Rio Grande do Norte (FNP, 2002). A produtividade média de melão rendilhado obtida de vários experimentos variou de cerca de 35 a $47 \mathrm{t} \mathrm{ha}^{-1}$ (Gusmão, 2001).

Atualmente, os principais melões produzidos comercialmente pertencem a dois grupos: Cucumis melo inodorus Naud. e Cucumis melo cantaloupensis Naud., que correspondem, aos melões inodoros e os aromáticos, respectivamente. Os melões do primeiro grupo são os denominados melões de 
inverno, que apresentam frutos com casca lisa ou levemente enrugada, coloração amarela, branca ou verde-escura. Os do segundo grupo incluem os melões anteriormente classificados como das variedades C. melo reticulatus e C. melo cantaloupensis, possuem frutos com superfície rendilhada, verrugosa ou escamosa, podendo ou não apresentar gomos, polpa com aroma característico, podendo ser de coloração alaranjada, salmão ou verde (característica do híbrido Bônus no 2) (Alves, 2000).

O melão rendilhado ou "net-melon", hortaliça largamente cultivada no Japão, chegou ao Brasil em 1990. Pertence ao grupo Cucumis melo cantaloupensis Naud., possui casca rendilhada, alto teor de açúcar, baixa conservação pós-colheita e menor resistência ao transporte. No Brasil, tem sido cultivado na região Nordeste, principalmente no pólo Mossoró-Açú. Produtores do município de Assai (Paraná), Capão Bonito e Pilar do Sul (São Paulo) também tem produzido esse melão com sucesso (Rostelato, 1997; Alves, 2000).

O meloeiro é uma planta anual, herbácea, possui hábito de crescimento rasteiro, com os ramos laterais, podendo atingir até três metros de comprimento. Possui sistema radicular fasciculado, com crescimento abundante nos primeiros $30 \mathrm{~cm}$ de profundidade (Araujo, 1980; Filgueira 2000).

O meloeiro adapta-se melhor aos climas quentes e secos, requerendo irrigação para suprir sua demanda hídrica, de acordo com o estádio de desenvolvimento, principalmente na floração e na frutificação. A época de plantio mais favorável ao meloeiro é de agosto a fevereiro, podendo ser

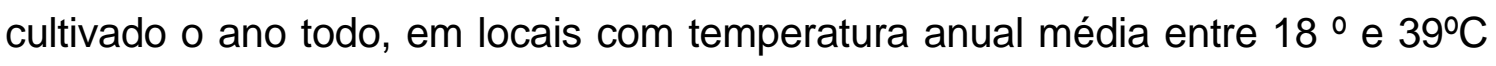
(Blanco et al., 1997).

O desenvolvimento vegetativo da planta diminui quando a temperatura do ar é inferior a $13^{\circ} \mathrm{C}$, paralisando a $1^{\circ} \mathrm{C}$. As temperaturas ideais estão entre $28^{\circ} \mathrm{C}$ e $32^{\circ} \mathrm{C}$ para germinação, $20^{\circ} \mathrm{C}$ e $23^{\circ} \mathrm{C}$ para floração e $25^{\circ} \mathrm{C}$ e $30^{\circ} \mathrm{C}$ para o desenvolvimento. No desenvolvimento inicial da planta, a umidade relativa deve 
ser entre 65 e 75\%, na floração entre 60 e 70\% e na frutificação entre 55 e $65 \%$ (Sousa et al., 1999a).

Normalmente, a floração do meloeiro tem início com o aparecimento da flor masculina, que surge duas a três semanas antes da flor feminina ou hermafrodita, e continua por todo o ciclo da planta. As flores masculinas localizam-se no ramo principal, enquanto que as flores hermafroditas nos ramos secundários (Brandão Filho \& Vasconcellos, 1998).

Os solos areno-argilosos e bem drenados são os mais favoráveis ao cultivo do meloeiro, que não tolera acidez e requer boa fertilidade, atingindo melhores produções em solos cujo pH se aproxime da neutralidade (acima de $6,5)$. Recomenda-se realizar a calagem sempre que a saturação por bases do solo for inferior a $60 \%$, devendo-se aplicar calcário suficiente para elevar esse valor para 75 a $80 \%$ (Pimentel, 1985).

O cultivo do melão em ambiente protegido eleva não somente a produção, mas também a qualidade dos frutos produzidos, pois o tutoramento na vertical facilita os tratos culturais, o controle fitossanitário, simplifica a colheita e evita danos às plantas, proporcionando maior ventilação, principalmente, durante o florescimento, o que favorece a polinização natural e a artificial, além de possibilitar um aumento na densidade de plantas, podendo beneficiar a produtividade (Sganzerla, 1990).

Para a produção de melão em ambiente protegido e a campo, a forma mais eficiente para o fornecimento de nutrientes é através da fertirrigação. No Estado de São Paulo, cerca de 70 a $80 \%$ das hortaliças cultivadas em ambiente protegido são fertirrigadas. É empregada em praticamente $100 \%$ da produção irrigada por gotejamento nos Estados Unidos, Espanha, Holanda, Austrália, Israel e África do Sul e em mais de $75 \%$ de toda a produção agrícola de Israel, sendo uma das principais práticas responsáveis pela obtenção de altas produtividades. Na Europa, tem sido considerada como o método mais racional, por realizar a otimização da adubação, respeitando o meio ambiente. Quanto à utilização da fertirrigação, uma das regiões pioneiras no Brasil foi o Nordeste, 
onde se produz cerca de $95 \%$ do melão sendo que $80 \%$ sob fertirrigação por gotejamento (Villas Bôas et al., 2001).

\subsection{Extração de nutrientes pelo meloeiro}

O conhecimento do conteúdo de nutrientes nas plantas, principalmente da parte colhida, é importante para avaliar-se a remoção desses nutrientes da área de cultivo, tornando-se um dos componentes necessários para as recomendações econômicas de adubação. Em média, as plantas possuem cerca de $5 \%$ de nutrientes minerais na massa de material seco, porém existem grandes diferenças entre espécies e as quantidades totais exigidas por uma cultura dependem da produtividade. Por outro lado, a absorção de nutrientes é diferente de acordo com a fase de desenvolvimento da planta, intensificando-se com o florescimento, a formação e o crescimento dos frutos (Haag et al., 1981; Vitti et al., 1994; Raij et al., 1996).

De forma geral, a absorção de nitrogênio, fósforo e potássio pelas culturas seguem a mesma tendência do acúmulo de material seco e a exigência destes macronutrientes pela cultura diminui à medida que o fruto amadurece. Em culturas como melão, tomate e pimenta, as quantidades exigidas de nutrientes são relativamente pequenas até o florescimento, quando, então a absorção de nutrientes se acelera, chegando ao máximo durante a frutificação (Papadopoulos, 1999).

A utilização de curvas de acúmulo de nutrientes para os diversos híbridos ou variedades cultivadas de hortaliças, como um parâmetro para a recomendação da adubação, mostra-se como uma boa indicação da necessidade de nutrientes em cada etapa de desenvolvimento da planta; contudo, essas informações são ainda bastante limitadas (Villas Bôas et al., 2001). Na ausência da curva de absorção de nutrientes, o acúmulo de material 
seco fornece uma boa aproximação da extração de nutrientes (Sousa \& Coelho, 2001).

As informações à respeito das exigências minerais do meloeiro são escassas ou antigas. Conforme (Silva et al., 2000), o nitrogênio e o potássio são os elementos extraídos em maiores quantidades pelo meloeiro, participando com mais de $80 \%$ do total de nutrientes extraídos (38\% e $45 \%$, respectivamente). A taxa de absorção de nutrientes pelo meloeiro é mais rápida após o início do florescimento, estendendo-se até a fase inicial da colheita.

Sagiv et al. $(1980)^{1}$, citados por Bar-Yosef (1999) verificaram para o melão variedade Gália, que o maior consumo de nitrogênio ocorreu entre 61 e 70 dias após a semeadura, enquanto que para o fósforo e potássio ocorreu no período entre 71 e 80 dias após a semeadura.

Em estudos realizados com cultivares de melão rendilhado, Canato (2001a) verificou que os teores de nutrientes na parte aérea apresentavam a seguinte seqüência: cálcio > potássio > nitrogênio > magnésio > fósforo enxofre $>$ ferro $>$ manganês $>$ zinco $>$ cobre. Nos frutos, a seqüência foi potássio $>$ nitrogênio $>$ cálcio $\sim$ fósforo $>$ magnésio $>$ enxofre $>$ ferro $>$ zinco $>$ manganês $>$ cobre.

Esse mesmo autor verificou que a seqüência de acúmulo de macronutrientes foi diferente para os cultivares de melão rendilhado estudados. O cultivar Bônus ํo 2 acumulou mais potássio, seguido pelo cálcio, enquanto que o cultivar Mission mais cálcio, seguido pelo potássio. Para os demais nutrientes, em ambos os cultivares, a seqüência foi: nitrogênio > magnésio > fósforo $>$ enxofre $>$ ferro $>$ manganês $>$ zinco $>$ cobre (Canato 2001b).

Tyler \& Lorenz (1964) verificaram que o período de crescimento mais rápido do melão (Cantaloupe) iniciou-se entre 70 e 80 dias após a emergência

1 SAGIV, B.; BAR-YOSEF, B.; ELIAH, E. Drip irrigation and fertilization of spring muskmelon at Besor. Bet Dagan: The Volcani Center, Division of Scientific Publications, (Publication, 17). 
da planta e que a absorção de nutrientes teve o mesmo comportamento que a produção de material seco. A absorção de nitrogênio e potássio foi quatro vezes maior do que a de fósforo e cálcio, e o dobro de magnésio. Tanto a produção de material seco como a absorção de nutrientes foi mais rápida no período entre o florescimento e a época de colheita. Resultado semelhante foi obtido por Maruyama et al., (2000) que obtiveram uma maior produção de material seco por planta na floração e na colheita, para o híbrido Bônus ํㅡ 2, cultivado em ambiente protegido.

Belfort (1985), em um trabalho de campo, verificou que o melão cultivar Valenciano Amarelo acumulou, em miligramas por planta, as seguintes quantidades de: nitrogênio $(23,08)$, fósforo $(3,46)$, potássio $(28,90)$, cálcio $(12,74)$, magnésio $(5,55)$ e enxofre $(1,59)$, aos 75 dias após a emergência (colheita) e a produção de material seco foi de $905,88 \mathrm{~g}$ distribuída em caule e ramos $(19,38 \%)$, folhas $(30,32 \%)$ e flores e frutos $(50,30 \%)$.

Hernández et al. (1995) em estudo com o melão (híbrido Early Dew), tutorado em ambiente protegido, verificaram que o cálcio foi o nutriente encontrado em maior quantidade na composição foliar $\left(51,5 \mathrm{~g} \mathrm{~kg}^{-1}\right)$ seguido pelo nitrogênio $\left(46,9 \mathrm{~g} \mathrm{~kg}^{-1}\right)$, potássio $\left(35,0 \mathrm{~g} \mathrm{~kg}^{-1}\right)$, fósforo $\left(4,6 \mathrm{~g} \mathrm{~kg}^{-1}\right) \mathrm{e}$ magnésio $\left(3,7 \mathrm{~g} \mathrm{~kg}^{-1}\right)$, aos 80 dias após o transplantio.

Carneiro Filho (2001), trabalhando em ambiente protegido, observou para o melão rendilhado, os seguintes teores nas folhas expressos em $\left(\mathrm{g} \mathrm{kg}^{-1}\right)$ para os macronutrientes e em ( $\mathrm{mg} \mathrm{Kg}^{-1}$ ) para os micronutrientes: 46,1 de nitrogênio; 3,3 de fósforo; 40,3 de potássio; 53,1 de cálcio; 11,6 de magnésio; 7,85 de enxofre, 13 de cobre; 499 de ferro; 43 de zinco; 140 de manganês e 33 de boro, no início da frutificação.

Rincón Sánchez et al. (1998) verificaram que as concentrações de nutriente no tecido da planta mudaram durante o desenvolvimento do meloeiro (Cucumis melo L. cv. Toledo) cultivado em ambiente protegido. Na colheita, as quantidades de nutrientes extraídas em g planta $^{-1}$ foi de: nitrogênio $(40,48)$, fósforo $(6,8)$, potássio $(41,3)$, cálcio $(32,6)$ e magnésio $(16,6)$. No fruto, as 
maiores quantidades acumuladas foram de nitrogênio, fósforo e potássio e nas folhas, de cálcio e magnésio.

Bernadac et al. (1996), em estudo sobre a acumulação de cálcio nos frutos de melão (Cucumis melo var Maestro), verificaram que $80 \%$ do cálcio foi absorvido durante a primeira metade do desenvolvimento dos frutos. Por outro lado, Alarcón et al. (1999) verificaram que a demanda pelo cálcio aumentou consideravelmente durante o período de crescimento vegetativo intenso do melão (Cucumis melo L. cv. Revigal), em ambiente protegido.

O número de informações deficiente relativa às exigências nutricionais do meloeiro, em especial do meloeiro rendilhado, bem como a variabilidade das respostas dos diferentes cultivares, quanto à extração de macronutrientes e micronutrientes, ressalta a importância do estudo de extração de nutrientes por este híbrido, que tem destaque nas condições brasileiras.

\subsection{Utilização de potássio na cultura do meloeiro}

O potássio é absorvido pelas raízes na forma de $\mathrm{K}^{+}$, sendo esse processo essencialmente ativo. Ele desempenha várias funções na planta: o controle da turgidez do tecido, a ativação de muitas enzimas envolvidas na respiração e fotossíntese, a abertura e fechamento de estômatos, o transporte de carboidratos, a transpiração, a resistência à geada, seca, salinidade e à doença, a resistência ao acamamento e a manutenção da qualidade dos produtos (Malavolta, 1980; Mengel \& Kirkby, 1987; Marschner, 1995).

De todos os nutrientes requeridos para o crescimento das plantas, os efeitos de potássio são os mais pronunciados, no aprimoramento da qualidade produtiva das culturas. Embora muitos dos processos pelos quais a nutrição potássica influencia a qualidade da cultura não sejam completamente compreendidos, tem-se verificado que ele promove estímulos de síntese de carboidrato, aumenta a espessura da casca, o tamanho e a acidez dos frutos, conferindo melhor qualidade física e melhor aparência ao produto, podendo 
estar relacionado com o sabor dos frutos e com a maior tolerância da cultura ao ataque de certas doenças e pragas, além de aumentar a resistência do fruto ao transporte e ao armazenamento (Pretty, 1982; Ferreira \& Pedrosa, 1982; Alves, 2000).

Para a cultura do meloeiro, embora sejam poucos os trabalhos envolvendo o efeito desse nutriente, alguns trabalhos mostram a sua importância na produtividade e na qualidade, além disso, os trabalhos de pesquisas mostram que a quantidade de potássio utilizada no seu cultivo é ainda bastante variada.

Prabhakar et al. (1985); Faria (1990) e Katayama (1993) verificaram aumentos na produtividade do melão devido ao aumento no peso dos frutos, ocasionado pelo acréscimo de potássio e, atribuíram esse resultado ao fato desse nutriente apresentar um papel importante na translocação de carboidratos. Resultados semelhantes foram obtidos por Faria et al. (1994), que obtiveram aumentos de $8 \%$ no peso médio dos frutos de melão cultivar Eldorado, provocado pelo potássio.

Carneiro Filho (2001) cultivou o híbrido Don Carlos em um espaçamento de $0,3 \mathrm{~m} \times 1,0 \mathrm{~m}$ e utilizou $142,5 \mathrm{~kg} \mathrm{ha}^{-1}$ de $\mathrm{K}_{2} \mathrm{O}$, obtendo uma produção total em torno de $38 \mathrm{t} \mathrm{ha}^{-1} \mathrm{em}$ ambiente protegido.

Gualberto et al. (2001), trabalhando com espaçamentos entre 0,3 a $0,7 \mathrm{~m}$ entre plantas e 0,5m entre linhas no cultivo do híbrido Bônus $\mathrm{n}^{\circ} 2$, utilizaram um total de $145 \mathrm{~kg} \mathrm{ha}^{-1}$ de $\mathrm{K}_{2} \mathrm{O}$, obtendo uma produtividade de $5,99 \mathrm{~kg} \mathrm{~m}^{-2} \mathrm{em}$ ambiente protegido.

Com o objetivo de avaliar o crescimento e absorção de nutrientes do melão cultivar Toledo, cultivado em ambiente protegido, utilizou-se $350 \mathrm{~kg} \mathrm{ha}^{-1}$ de potássio e uma densidade de 0,5 planta $\mathrm{m}^{-2}$, e obteve-se uma produção de frutos de 5,32 $\mathrm{kg} \mathrm{m}^{-2}$ (Rincón Sánchez et al., 1998).

Sagiv et al. (1980) citados por Bar-Yosef (1999) verificaram que para o melão variedade Galia, cultivado numa população de 25.000 plantas ha ${ }^{-1}$, 
utilizando-se as doses de $151 \mathrm{~kg} \mathrm{ha}^{-1}$ de nitrogênio, $25 \mathrm{~kg} \mathrm{ha}^{-1}$ de fósforo e 385 $\mathrm{kg} \mathrm{ha}^{-1}$ de potássio, a produtividade foi de $56 \mathrm{tha}^{-1}$ de frutos comerciais.

Em um trabalho com as doses de $\left(100,190,280\right.$ e $370 \mathrm{~kg} \mathrm{ha}^{-1}$ de $\left.\mathrm{K}_{2} \mathrm{O}\right) \mathrm{e}$ 100; 160; 220 e $280 \mathrm{~kg} \mathrm{ha}^{-1}$ de nitrogênio, Sousa et al. (1998b) constataram que a maior produtividade comercial $\left(44,34 \mathrm{t} \mathrm{ha}^{-1}\right)$ do meloeiro foi obtida com a combinação de $160 \mathrm{~kg} \mathrm{ha}^{-1}$ de nitrogênio e $190 \mathrm{~kg} \mathrm{ha}^{-1}$ de $\mathrm{K}_{2} \mathrm{O}$, entretanto, com $100 \mathrm{~kg} \mathrm{ha}^{-1}$ de nitrogênio houve uma tendência de aumento da produtividade com doses de $\mathrm{K}_{2} \mathrm{O}$ maiores que $190 \mathrm{~kg} \mathrm{ha}^{-1}$.

Sousa et al. (1998c) utilizaram $100 \mathrm{~kg} \mathrm{ha}^{-1}$ de nitrogênio e $370 \mathrm{~kg} \mathrm{ha}^{-1} \mathrm{de}$ $\mathrm{K}_{2} \mathrm{O}$, para uma densidade de 25.000 plantas $\mathrm{ha}^{-1}$, quando obtiveram uma produtividade de $63,87 \mathrm{tha}^{-1}$.

Em Petrolina, PE, com o objetivo de avaliar fontes e métodos de aplicação de fósforo para o cultivo do melão Valenciano Amarelo em campo no espaçamento de $0,5 \times 1,8 \mathrm{~m}$, foi utilizado um total de $90 \mathrm{~kg} \mathrm{ha}^{-1}$ de $\mathrm{P}_{2} \mathrm{O}_{5}, 80 \mathrm{~kg}$ ha $^{-1}$ de nitrogênio e $120 \mathrm{~kg} \mathrm{ha}^{-1}$ de $\mathrm{K}_{2} \mathrm{O}$, sendo a maior produtividade de frutos comerciais obtida de 27,42 $\mathrm{t} \mathrm{ha}^{-1}$ (Brito et al., 1999).

Em Mossoró, RN em uma população de 20.000 plantas ha $^{-1}$ do melão Valenciano cultivar Gold Mine utilizaram-se um total de $243 \mathrm{~kg} \mathrm{ha}^{-1}$ de potássio (Dias et al.,2000).

Para o cultivo em campo do melão cultivar Eldorado 300 no espaçamento de $0,5 \times 1,8 \mathrm{~m}$ e em uma área útil de $36 \mathrm{~m}^{2}$, utilizou-se a dose de $120 \mathrm{~kg} \mathrm{ha}^{-1}$ de $\mathrm{K}_{2} \mathrm{O}, 120 \mathrm{~kg} \mathrm{ha}^{-1}$ de $\mathrm{P}_{2} \mathrm{O}_{5}$ e $180 \mathrm{~kg} \mathrm{ha}^{-1}$ de nitrogênio em Juazeiro, BA, obtendo-se a produtividade de $37,71 \mathrm{t} \mathrm{ha}^{-1}$ (Faria et al., 2000). No entanto, nessa mesma cidade, esses autores verificaram que ao utilizarem doses de $0,60,120,180$ e $240 \mathrm{~kg} \mathrm{ha}^{-1}$ de $\mathrm{K}_{2} \mathrm{O}$, a dose de $165 \mathrm{~kg} \mathrm{ha}^{-1}$ foi a que proporcionou a máxima produtividade esperada (Faria et al., 1994).

A recomendação da dose de potássio baseia-se em informações que relacionam a resposta das plantas à adubação e os teores do nutriente no solo.

Brandão Filho \& Vasconcellos (1998) recomendam a aplicação de $200 \mathrm{~kg}$ $\mathrm{ha}^{-1}$ de potássio e Pereira \& Marchi (2000) a quantidade de $144 \mathrm{~kg} \mathrm{ha}^{-1}$ de $\mathrm{K}_{2} \mathrm{O}$. 
Vivancos (1993) de 200 a $450 \mathrm{~kg} \mathrm{ha}^{-1}$ de $\mathrm{K}_{2} \mathrm{O}$ para obter-se de 20 a $40 \mathrm{t} \mathrm{ha}^{-1}$ de produção.

No Estado de São Paulo, Raij et al. (1996) recomendam para o melão amarelo, na adubação mineral de plantio, a quantidade de 30; 60 e $90 \mathrm{~kg} \mathrm{ha}^{-1}$ de $\mathrm{K}_{2} \mathrm{O}$ quando o teor $\left(\mathrm{mmol}_{\mathrm{c}} \mathrm{dm}^{-3}\right.$ ) de $\mathrm{K}^{+}$no solo for de 0 a 1,5; 1,6 a 3,0; e maior que 3,0 respectivamente, e para a adubação mineral de cobertura a quantidade de 50 a $100 \mathrm{~kg} \mathrm{ha}^{-1}$ de $\mathrm{K}_{2} \mathrm{O}$.

$\mathrm{Na}$ região norte de Minas Gerais, recomenda-se para a adubação mineral de fundação a quantidade de 40; 80; 120 e $160 \mathrm{~kg} \mathrm{ha}^{-1}$ de $\mathrm{K}_{2} \mathrm{O}$ quando o teor $\left(\mathrm{mg} \mathrm{dm}^{-3}\right)$ de $\mathrm{K}^{+}$no solo for de 2,3 a 3,0; 1,5 a 2,3; 0,7 a 1,5; e de 0 a 0,7, respectivamente, para obter-se uma produtividade de até $40 \mathrm{t} \mathrm{ha}^{-1}$ (Silva et al., 2000).

Para as condições de solos arenosos do Médio São Francisco, as doses recomendadas para o espaçamento de $0,5 \times 1,8 \mathrm{~m}$ tem sido de $80 \mathrm{~kg} \mathrm{ha}^{-1}$ de N e $90 \mathrm{~kg} \mathrm{ha}^{-1}$ de $\mathrm{K}_{2} \mathrm{O}$ para uma produtividade de $38,9 \mathrm{t} \mathrm{ha}^{-1}$ (Pinto et al., 1996). Nas condições dos Tabuleiros Costeiros do Piauí, considerando o espaçamento de $0,2 \times 2,0 \mathrm{~m}$ e aplicação de $120 \mathrm{~kg} \mathrm{ha}^{-1}$ de $\mathrm{N}$ e $150 \mathrm{~kg} \mathrm{ha}^{-1}$ de $\mathrm{K}_{2} \mathrm{O}$ para os cultivares Eldorado 300 e Gold Mine, as produtividades obtidas estão em torno de $50 \mathrm{t} \mathrm{ha}^{-1}$ (Sousa et al., 1999a).

Para o cultivo do melão rendilhado, em ambiente protegido, verificou-se pelos trabalhos encontrados, que alguns autores como Maruyama (1999), Rizzo \& Braz (2001) e Gusmão (2001) utilizaram a quantidade de potássio conforme a recomendação para o melão amarelo proposta por Raij et al. (1996), percebendo-se dessa forma, a necessidade de estudos de respostas desses cultivares à adubação potássica.

\subsection{Utilização de dióxido de carbono $\left(\mathrm{CO}_{2}\right)$ na água de irrigação}

Durante os últimos anos, o interesse pelo enriquecimento dos sistemas com $\mathrm{O} \quad \mathrm{CO}_{2}$ tem aumentado consideravelmente, visando um melhor 
entendimento científico da forma como as plantas respondem, em diferentes condições climáticas, e aos problemas de poluição do ar (Mortensen, 1987).

A utilização de $\mathrm{CO}_{2}$ via água de irrigação (água carbonatada), como uma técnica para o desenvolvimento das plantas, tem sido estudada em outros países há mais de cem anos. Verifica-se que tanto em ambiente protegido, como em campo aberto, que essa técnica pode aumentar significativamente a produção (Mauney \& Hendrix, 1988; Novero et al., 1991). Por outro lado, œ trabalhos de Hartz \& Holt, (1991); Storlie, (1992) ${ }^{2}$ citado por Storlie \& Heckman (1996a); Stoffella et al., (1995) mostram que não foi encontrado efeito do $\mathrm{CO}_{2}$ sobre a produção.

No Brasil, entretanto, os trabalhos com a utilização dessa técnica são escassos, destacando-se os desenvolvidos por Pinto (1997), Cararo (2000), Furlan et al. (2001), Gomes (2001) e Araújo (2002), que obtiveram aumentos da produtividade em melão, tomate, alface e abobrinha, respectivamente, com a utilização da água carbonatada.

Desde o final do século passado, já se utilizava essa técnica como um recurso para incrementar a produtividade e a qualidade das plantas ornamentais. $\mathrm{O}$ enriquecimento com $\circ \mathrm{CO}_{2}$ tem sido realizado diretamente na atmosfera (maioria dos trabalhos sobre esse assunto) ou junto com a água de irrigação, sendo este último modo o mais indicado para as condições brasileiras, pelo fato de não aumentar a temperatura no interior do ambiente protegido, além de otimizar os equipamentos de irrigação já instalados. Atualmente no Brasil, essa técnica vem sendo aplicada com sucesso na floricultura e na fruticultura irrigada (Durão \& Galvão, 1995).

As concentrações ótimas de $\mathrm{CO}_{2}$ para se ter um melhor crescimento e uma maior produção, geralmente recomendadas para ambientes protegidos encontra-se entre 700 e $900 \mu \mathrm{mol} \mathrm{mol}{ }^{-1}$, já que as concentrações acima de

2 STORLIE, C.A. Soil and plant responses to $\mathbf{C O}_{2}$ fertigation. St. Joseph: ASAE, 1992. (ASAE. Paper, 92-2571). 
$1000 \mu \mathrm{mol} \mathrm{mol}^{-1}$ podem causar redução no crescimento e injúrias nas folhas (Mortensen, 1987).

Já na década de 60, os trabalhos encontrados, procuraram demonstrar os efeitos da utilização de água de irrigação com altas quantidades de $\mathrm{HCO}_{3}{ }^{-}$ sobre a absorção de nutrientes, em algumas espécies de plantas (Brown, 1960; Rhoads \& Wallace, 1960; Hale \& Wallace, 1960; Miller, 1960; Bhan et al., 1960).

A forma do carbono inorgânico dissolvido $\left(\mathrm{CO}_{2}, \mathrm{HCO}_{3}{ }^{-}\right.$e/ou $\left.\mathrm{CO}_{3}{ }^{2-}\right)$, comumente fornecido às plantas, é a de gás de $\mathrm{CO}_{2}$ ou como $\mathrm{HCO}_{3}{ }^{-}$dissolvido na irrigação ou na solução de nutrientes (Golterman and Clymo, $1969^{3}$ citados por Cramer et al., 2001).

Segundo Hanan (1998) e Parker \& Norvell (1999), o $\mathrm{CO}_{2}$, quando dissolvido em água na forma de $\mathrm{CO}_{2}{ }^{\circ}$ torna-se ácido carbônico não dissociado $\left(\mathrm{H}_{2} \mathrm{CO}_{3}{ }^{\circ}\right)$.

$$
\mathrm{CO}_{2} \text { (gás) }+\mathrm{H}_{2} \mathrm{O} \rightarrow \mathrm{H}_{2} \mathrm{CO}_{3}{ }^{\circ}
$$

Em solução, o ácido carbônico dissocia para formar:

$$
\mathrm{H}_{2} \mathrm{CO}_{3} \stackrel{0}{\leftarrow} \underset{\mathrm{H}^{+}}{+}+\mathrm{HCO}_{3}^{-}
$$

No solo, o dióxido de carbono pode combinar-se com os íons hidrogênio $\left(\mathrm{H}^{+}\right)$da solução do solo, para formar ácido carbônico $\left(\mathrm{H}_{2} \mathrm{CO}_{3}\right)$ ou com os cátions, podendo produzir carbonatos e bicarbonatos de cálcio, potássio e magnésio (Smith et al., 1991).

Alguns benefícios da utilização da água carbonatada no desenvolvimento das plantas têm sido estudados, destacando-se o fato de que o aumento da concentração de $\mathrm{CO}_{2}$ no ar do solo pode causar o aumento na concentração de íons hidrogênio com abaixamento relativamente temporário do $\mathrm{pH}$ da solução

${ }^{3}$ GOLTERMAN, H.L.; CLYMO, R.S., Methods for chemical analysis of fresh waters. Oxford: Blackwell Scientific, 1969. p. 140-143 (IBP. Handbook, 8). 
do solo, podendo aumentar a disponibilidade de alguns nutrientes para as plantas (Basile et al., 1993), promovendo a absorção de nutrientes (Novero et al., 1991), favorecendo o desenvolvimento de certos microorganismos benéficos no solo, aumentando a resistência das plantas aos estresses hídricos (Lemon, $1983^{4}$ e Baker, 19885 ; citados por Moore, 1990).

Dois mecanismos possíveis podem ser considerados para aumentar-se a absorção dos nutrientes. Primeiro, a disponibilidade de certos nutrientes pode aumentar devido ao abaixamento do $\mathrm{pH}$ do solo, ocasionado pela aplicação do $\mathrm{CO}_{2}$ via água de irrigação. Segundo, $\mathrm{O}_{\mathrm{CO}_{2}}$ pode induzir um aumento do crescimento de raízes, agindo de forma semelhante a um fitormônio, num equilíbrio competitivo, com a concentração de etileno no ar do solo (Govindarajan \& Poovaiah, 1984; Chaudhuri et al., 1990; Novero et al., 1991).

$\mathrm{O}$ aumento na absorção de nutrientes pelas plantas que receberam $\mathrm{CO}_{2}$, via água de irrigação, pode ser verificado em alguns trabalhos.

Ibrahim (1992), avaliando doses de $\mathrm{CO}_{2}\left(0 ; 50 ; 150\right.$ e $200 \mathrm{mg} \mathrm{CO}_{2} \mathrm{~L}^{-1}$ de água de irrigação), verificaram em folhas de plantas de pepino, um aumento na concentração de potássio, magnésio, zinco e cobre quando a concentração de $\mathrm{CO}_{2}$ estava acima de $100 \mu \mathrm{mol} \mathrm{mol}^{-1}$.

Para o tomateiro, D'Andria et al. (1993) verificaram nos frutos, que a concentração de zinco, cobre, ferro e manganês aumentaram inicialmente com a utilização da água carbonatada, sendo que, no período ao longo da colheita, as concentrações passaram a serem semelhantes (zinco e manganês) ou menores (cobre e ferro) do que o da testemunha. Nessa mesma cultura, Novero et al. (1991) observaram aumentos significativos nos teores de zinco nas folhas

${ }^{4}$ LEMON, E.R. (Ed.) $\mathbf{C O}_{2}$ and plants. Westview Boulder: Press, 1983. 280p. (AAAS. Selected Symposium, 84).

${ }^{5}$ BAKER, R., Trichoderma spp.: as plant-growth stimulants. Critical Reviews in Biotechnology, v.7, n.2, p.97-106, 1988. 
das plantas que receberam água carbonatada em relação à testemunha. No entanto, Cararo (2000) trabalhando com a dose de 7,73 $\mathrm{g} \mathrm{L}^{-1}$, verificou nos frutos, uma redução nos teores de zinco, resultados semelhantes aos obtidos por Kimball et al. (1986).

Storlie \& Heckman (1996b) não verificaram diferenças na concentração de nutrientes e na produtividade de plantas de pimentão cultivadas com a concentração de $1,2 \mathrm{~g} \mathrm{~L}^{-1}$ de $\mathrm{CO}_{2}$.

Arteca et al. (1979) observaram incrementos nos teores de cálcio e magnésio, quando submeteram raízes de batata a uma solução com alta concentração de $\mathrm{CO}_{2}$.

Stoffella et al. (1995) utilizando a dose de $1,362 \mathrm{mg} \mathrm{L}^{-1}$, não obtiveram aumentos na concentração de macronutriente nas folhas de mudas de citrus cultivados com um enriquecimento de $\mathrm{CO}_{2}$ na água de irrigação, contudo, a concentração de zinco aumentou e a do manganês diminuiu.

No algodoeiro, Mauney \& Hendrix (1988), trabalhando com concentrações entre 1,5 a $1,8 \mathrm{~g} \mathrm{~L}^{-1}$ de $\mathrm{CO}_{2}$ na água de irrigação, verificaram que a água carbonatada acarretou uma maior absorção de zinco e de manganês.

Para a cultura do meloeiro, são poucos os resultados de pesquisa sobre a utilização de água carbonatada. Pinto (1997), trabalhando com a aplicação de cerca de $50 \mathrm{~kg} \mathrm{ha}^{-1}$ de $\mathrm{CO}_{2}$ na água de irrigação, e utilizando a dose total de $180 \mathrm{~kg} \mathrm{ha}^{-1}$ de potássio no cultivo do melão cultivar Valenciano Amarelo e um espaçamento de $0,6 \times 2,0 \mathrm{~m}$, obteve um incremento de $27,3 \%$ na produtividade, entretanto, não obteve diferenças para os teores de nutrientes nas folhas, exceto para o boro. Além disso, a eficiência do uso da água pela cultura, aumentou com o uso desta técnica, o que pode ser atribuído ao maior desenvolvimento do sistema radicular.

Quanto ao efeito do $\mathrm{CO}_{2}$ na extração de macronutrientes e micronutrientes, para o meloeiro rendilhado, não foram encontrados resultados 
para as condições brasileiras, evidenciando a necessidade da avaliação do efeito dessa técnica. 


\section{MATERIAL E MÉTODOS}

\subsection{Localização e características da área experimental}

Esse trabalho foi conduzido em duas estufas para cultivo protegido localizadas na área experimental do Departamento de Engenharia Rural, pertencente à Escola Superior de Agricultura "Luiz de Queiroz" - USP/ESALQ, no município de Piracicaba, SP, latitude de $22^{\circ} 42^{\prime} 30^{\prime \prime S}$, longitude $47^{\circ} 38^{\prime} 00^{\prime \prime} \mathrm{W}$ e altitude de $580 \mathrm{~m}$.

Conforme a classificação climática de Köppen, o clima da região é mesotérmico do tipo Cwa, subtropical úmido, com verão chuvoso e inverno seco. A temperatura média mensal varia de $24,8^{\circ} \mathrm{C}$ (verão) a $17,1^{\circ} \mathrm{C}$ (inverno), com a média anual de $21,4^{\circ} \mathrm{C}$. A pluviosidade média anual é de $1.278 \mathrm{~mm}$, ocorrendo aproximadamente $1000 \mathrm{~mm}$ de outubro a março e $278 \mathrm{~mm}$ de abril a setembro (Sentelhas, 1998).

\subsection{Delineamento experimental e tratamentos}

Foram realizados dois experimentos, um com a aplicação de $\mathrm{CO}_{2}$ em dose pré-definida e outro considerando o sistema convencional ( $\mathrm{sem} \mathrm{CO}_{2}$ ).

$O$ delineamento experimental utilizado em cada estufa foi 0 de blocos casualizados, com quatro doses de potássio: 50; 150; 300 e $600 \mathrm{~kg} \mathrm{ha}^{-1}$ de $\mathrm{K}_{2} \mathrm{O}$ e quatro repetições que corresponderam aos quatro blocos.

Em cada estufa utilizou-se seis canteiros de plantas construídas no sentido longitudinais, sendo que os dois canteiros externos constituíram as 
bordaduras. As parcelas, constituídas por 13 plantas espaçadas de 0,30m foram distribuídas aleatoriamente nos quatro canteiros centrais.

\subsection{As estufas}

As duas estufas em arco (Figura 1), foram instaladas no sentido lesteoeste e apresentavam as seguintes dimensões: $17,5 \mathrm{~m}$ de comprimento, largura de $7,0 \mathrm{~m}$ e pé-direito de $3,0 \mathrm{~m}$, e os arcos, na sua parte mais alta, atingiam a altura de 4,7m. Sob cada arco tinham duas janelas para liberar o ar quente que acumula-se no alto da estufa. As fachadas laterais e frontais foram feitas com tela de nylon branca de $1,0 \mathrm{~mm}$ e apresentavam um rodapé de concreto de $0,30 \mathrm{~m}$ de altura. $\mathrm{O}$ teto foi coberto com filme de polietileno transparente com 150 micras de espessura, com tratamento anti-UV. As fachadas laterais e frontais das estufas também foram fechadas com a mesma tela e apresentavam um sistema de manivela que possibilitava o fechamento e a abertura das cortinas de filme de polietileno transparente.

Não houve controle artificial da temperatura e da umidade relativa no ambiente, utilizando-se apenas o manejo das janelas e das cortinas, com base nas variações da temperatura e da umidade relativa observadas nos termohigrógrafos portáteis colocados dentro das estufas. 


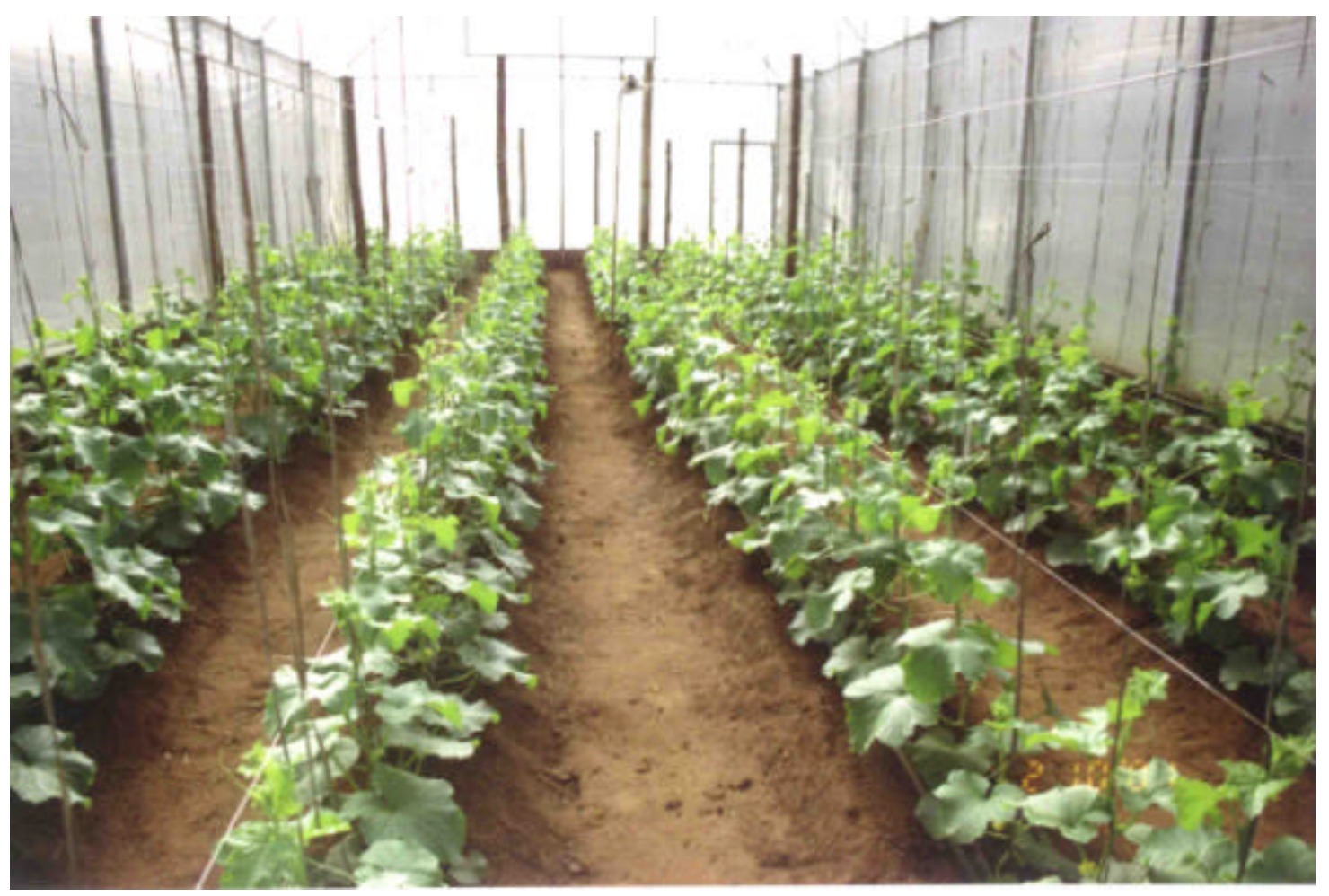

Figura 1 - Vista geral de uma estufa.

\subsubsection{Características do solo dos canteiros}

Foram construídos seis canteiros dentro de cada estufa, e pelo fato de a estufa estar situada em uma área de terraplanagem, foram feitas valas de $0,5 \mathrm{~m}$ $\times 0,40 \mathrm{~m} \times 15 \mathrm{~m}$, onde foi colocada a parte de um solo proveniente da camada de 0,0 a 0,3m de uma área não cultivada, classificado como LATOSSOLO VERMELHO-AMARELO Distrófico típico (Embrapa, 1999).

Os canteiros foram construídos com uma altura de $0,10 \mathrm{~m}$ acima do nível do terreno, proporcionando uma profundidade de 0,50 m para exploração pelas raízes. Cada canteiro foi servido por uma linha para irrigação e outra para fertirrigação. 


\subsubsection{Calagem e adubação de plantio}

A caracterização físico-química do solo (Tabelas 1 e 2) foi feita mediante análise de amostras compostas coletadas logo após a construção dos canteiros das duas estufas na camada de $0.30 \mathrm{~cm}$ de profundidade, para quantificar a necessidade de calagem, adubação de plantio (fósforo) e de cobertura (nitrogênio).

Tabela 1. Resultados da análise textural do solo utilizado nos experimentos, proveniente da camada de 0,0 a 0,3m de uma área não cultivada

\begin{tabular}{lllll}
\hline Argila & Silte & Areia & \multicolumn{2}{c}{ Densidade $\left(\mathrm{g} \mathrm{cm}^{-3}\right)$} \\
-------------- & $\left(\mathrm{g} \mathrm{kg}^{-1}\right)$ & -------------- & Global & de Partículas \\
\hline 152,3 & 86,7 & 761,0 & 1,08 & 2,66 \\
\hline
\end{tabular}

Tabela 2. Resultados da análise química do solo utilizado nos experimentos, proveniente da camada de 0,0 a $0,3 \mathrm{~m}$ de área não cultivada

\begin{tabular}{cccccccccc}
\hline $\mathrm{P}$ & $\mathrm{M} . \mathrm{O}$. & $\mathrm{K}^{+}$ & $\mathrm{Ca}^{+2}$ & $\mathrm{Mg}^{+2}$ & $\mathrm{H}+\mathrm{Al}^{3+}$ & $\mathrm{pH}$ & $\mathrm{S}$ & $\mathrm{T}$ & $\mathrm{V}$ \\
$\left(\mathrm{mg} \mathrm{dm}^{-3}\right)$ & $\left(\mathrm{g} \mathrm{dm}^{-3}\right)$ & - & & & & & & & \\
\hline 4,0 & 13,8 & 0,9 & 7,5 & 3,3 & 27,8 & 4,6 & 11,9 & 39,7 & 30 \\
\hline
\end{tabular}

Com base na análise química do solo, procedeu-se a correção da acidez do solo, 60 dias antes do plantio, mediante a incorporação nos canteiros de uma dose de 2,96 t ha-1 de calcário dolomítico (390 $\mathrm{g} \mathrm{kg}^{-1}$ de $\mathrm{CaO}, 130 \mathrm{~g} \mathrm{~kg}^{-1}$ de MgO e PRNT de 67\%), seguindo-se a recomendação de calagem sugerida por Raij et al. (1996), visando elevar-se a saturação por bases a $80 \%$ e o teor de magnésio a $9,0 \mathrm{mmol}_{\mathrm{c}} \mathrm{dm}^{-3}$. 
Decorridos 30 dias da calagem e 30 dias antes do transplantio, foi feita a adubação de plantio, aplicando-se uma dose de $240,0 \mathrm{~kg}^{-1}$ de $\mathrm{P}_{2} \mathrm{O}_{5}$ na forma de termofosfato Yoorin master $\left(17,5 \%\right.$ de $\mathrm{P}_{2} \mathrm{O}_{5}, 0,10 \%$ de $\mathrm{B}$ e $0,55 \%$ de $\mathrm{Zn}$ ) e 30,0 t ha-1 de esterco bovino curtido baseando-se na recomendação de adubação de plantio sugerida por Raij et al. (1996) para o meloeiro. Após 30 dias da adubação de plantio foi feita uma nova análise química do solo, onde se verificou, pelas características químicas, que as condições eram adequadas para o cultivo do meloeiro.

\subsection{Condução das plantas}

\subsubsection{Mudas}

As mudas de meloeiro rendilhado (Cucumis melo L. var reticulatus Naud.) híbrido Bônus no 2 foram preparadas em bandejas de poliestireno expandido com 128 células preenchidas com substrato comercial colocando-se uma semente por célula, no mês de agosto de 2001. A umidade das bandejas foi mantida diariamente, sendo que a aplicação de água terminava depois de constatado o início do gotejamento na parte inferior da bandeja. O período de formação das mudas foi de 19 dias após a semeadura, quando a segunda folha definitiva foi emitida.

\subsubsection{Transplantio das mudas}

As mudas foram transplantadas no dia 04 de setembro de 2001 (19 dias após a semeadura), utilizando-se um espaçamento de 0,30 m x 1,10 m, resultando numa densidade de 30.303 plantas $\mathrm{ha}^{-1}$. Ao término do transplantio, realizou-se a primeira irrigação até que se formou uma faixa molhada contínua, para auxiliar na adaptação das plantas ao novo ambiente. 


\subsubsection{Sistema de condução}

Em cada canteiro, instalaram-se mourões de madeira com três fios de arame liso if 12, esticados paralelos na horizontal a 0,7 m, 1,5 m e 2,0 m de altura, onde as plantas foram conduzidas com uma haste e tutoradas na vertical.

A desbrota foi feita até $011^{\circ}$ nó do caule, cerca de $0,7 \mathrm{~m}$ do colo da planta, deixando os demais brotos laterais com três folhas até a planta atingir o último fio de arame, quando foi feita a poda apical, utilizando-se tesouras apropriadas para os cortes em hastes tenras, esterilizadas numa solução fungicida-bactericida. Quando as plantas iniciaram a emissão das gavinhas, envolveu-se o cólon da planta com um gancho de arame e nele amarrou-se um fitilho de plástico para auxiliar na condução da planta na vertical até o último arame.

Como o cultivo foi conduzido em ambiente fechado, procedeu-se a polinização artificial por 15 dias consecutivos a partir do surgimento das primeiras flores femininas (40 dias após o transplantio).

\subsubsection{Controle fitossanitário}

O controle fitossanitário foi feito com base nas recomendações técnicas (Sousa et al., 1999a; Silva et al., 2000), por meio das aplicações preventivas e de controle, com produtos defensivos químicos e naturais a cada sete dias em média e sempre que necessário.

As plantas daninhas foram controladas aos 30 dias após o transplantio por meio de capina manual, sendo em seguida realizada a amontoa, refazendose o canteiro. 


\subsection{Irrigação}

Aos 60 dias após a conclusão dos canteiros, quando a terra dos mesmos já havia acomodado, determinou-se a densidade global e a curva de retenção de água da camada de $0-30 \mathrm{~cm}$ de profundidade.

Pelo teor de areia do solo $\left(761,0 \mathrm{~g} \mathrm{~kg}^{-1}\right)$ e pela curva de retenção de água, verificou-se que o solo apresentava textura leve e baixa capacidade de retenção de água.

A água utilizada para a irrigação foi proveniente do sistema de abastecimento de água potável da ESALQ. Realizou-se a análise de qualidade dessa água e, de um modo geral, os resultados da análise de água não indicaram limitações para a irrigação.

O sistema de irrigação utilizado foi o por gotejamento, constituído por seis linhas laterais em cada estufa. Cada linha lateral com $15,0 \mathrm{~m}$ de comprimento e espaçada em $1,10 \mathrm{~m}$ era composta de tubo gotejador de polietileno espaçados de $0,20 \mathrm{~m}$, com vazão de $1,3 \mathrm{~L} \mathrm{~h}^{-1}$. A vazão média de água que entrava em cada estufa para abastecer as linhas de irrigação era de $9,2 \mathrm{Lh}^{-1}$.

Após a instalação do sistema de irrigação, determinou-se a uniformidade de distribuição de água pelos gotejadores em cada estufa, utilizando-se duas linhas úteis de gotejadores e quatro emissores por linha: o primeiro (1/1), o último (3/3) e os situados a 1/3 e a 2/3 do comprimento da linha. Os resultados do ensaio de uniformidade de distribuição de água (UD) foram classificados como de uniformidade excelente.

A primeira irrigação foi realizada em tempo suficiente para proporcionar a formação de uma faixa molhada no solo ao longo das fileiras das plantas, com umidade próxima da capacidade de campo até $0,2 \mathrm{~m}$ de profundidade.

A freqüência de irrigação foi de dois dias e a quantidade de água aplicada foi calculada em função do potencial mátrico da água no solo no momento da irrigação. Essa quantidade de água foi determinada indiretamente 
com base na curva de retenção de água no solo e nas leituras diárias médias de tensão de água, realizadas com leitor digital em quatro baterias com quatro tensiômetros, instalados em cada estufa a $0,10 \mathrm{~m}, 0,20 \mathrm{~m}, 0,30 \mathrm{~m}$ e $0,40 \mathrm{~m}$ de profundidade. Procurou-se manter a tensão de água no solo entre $10,0 \mathrm{kPa}$ e $15 \mathrm{kPa}$, conforme sugerido por Carrijo et al. (1999).

Nos primeiros 30 dias após o transplantio foram utilizados os tensiômetros instalados a $0,10 \mathrm{~m}$ para controlar a irrigação na camada de solo de $0-0,20 \mathrm{~m}$ de profundidade. Após esse período, foram utilizados os tensiômetros instalados a $0,20 \mathrm{~m}$ para controlar a irrigação na camada de solo de $0-0,40 \mathrm{~m}$ de profundidade.

Os tensiômetros instalados a $0,20 \mathrm{~m}$ de profundidade indicaram $\mathrm{O}$ momento de irrigar e os demais serviram para controlar a frente de molhamento e a adequação da lâmina de água. A lâmina de irrigação foi transformada em volume e o tempo de irrigação controlado com base na vazão de água que entrava em cada estufa, medida por hidrômetros.

\subsection{Fertirrigação, aplicação de potássio e dióxido de carbono $\left(\mathrm{CO}_{2}\right)$}

\subsubsection{O sistema de fertirrigação e aplicação de fertilizantes}

O sistema de fertirrigação operou de forma independente do sistema de irrigação. A cada fertirrigação, aplicava-se apenas água até que as linhas de um mesmo tratamento de potássio ficassem pressurizada e em seguida injetava-se, com uma bomba centrífuga $(0,5 \mathrm{CV})$ um volume conhecido de calda fertilizante, a partir de um reservatório específico, de onde a calda era succionada e distribuída para as linhas de gotejadores (uma em cada estufa). Esse processo durava aproximadamente 5 minutos. A fertirrigação foi realizada de modo a possibilitar uma aplicação seqüenciada e independente dos tratamentos de potássio. Após a injeção da calda fertilizante de cada tratamento, aplicava-se 
mais um volume conhecido de água, para a lavagem do sistema e expulsão do restante da calda fertilizante nas linhas laterais.

A aplicação de fertilizantes foi iniciada quatro dias após o transplantio, com freqüência de quatro dias, totalizando 19 fertirrigações realizada até o $76^{\circ}$ dia após o transplantio. Durante o ciclo da cultura foram aplicados $200 \mathrm{~kg} \mathrm{ha}^{-1}$ de $\mathrm{N}$ em cobertura, na forma de nitrato de potássio e nitrato de amônio até 64 dias após o transplantio em todas parcelas.

\subsubsection{Aplicação de potássio}

A marcha de absorção de nutrientes do meloeiro adaptada para o experimento, apresentada por Silva et al. (2000) sugere que as maiores quantidades de nitrogênio não sejam aplicadas no final do ciclo, por isso, as doses de $\mathrm{K}_{2} \mathrm{O}$ variaram de acordo com o tratamento proposto e foram aplicadas na forma de nitrato de potássio até 64 dias após o transplantio e na forma de sulfato de potássio entre os 64 dias até 76 dias após o transplantio. Cada dose de potássio foi injetada separadamente nas linhas do sistema de fertirrigação (uma linha em cada estufa). A definição do parcelamento das doses de potássio e nitrogênio ao longo do ciclo do meloeiro foi baseada nessa marcha de absorção de nutrientes (Tabela 3).

As doses de potássio utilizadas no experimento $(50 ; 150 ; 300$ e $600 \mathrm{~kg}$ $\mathrm{ha}^{-1}$ de $\mathrm{K}_{2} \mathrm{O}$ ) foram baseadas na literatura referente a essa cultura e ao trabalho de Vivancos (1993), que cita a recomendação de 200 a $450 \mathrm{~kg} \mathrm{ha}^{-1}$ de $\mathrm{K}_{2} \mathrm{O}$ para obtenção de uma produção de 20 a $40 \mathrm{t} \mathrm{ha}^{-1}$. 
Tabela 3. Extração de $\mathrm{N}$ e $\mathrm{K}\left(\% \mathrm{ha}^{-1} \mathrm{dia}^{-1}\right)$ para o meloeiro cultivado com fertirrigação via gotejamento em diferentes fases do ciclo do desenvolvimento (adaptado de Silva et. al, 2000)

\begin{tabular}{ccc}
\hline $\begin{array}{c}\text { Dias após a } \\
\text { germinação }\end{array}$ & $\mathrm{N}$ & Extração $\left(\% \mathrm{ha}^{-1} \mathrm{dia}^{-1}\right)$ \\
\hline $1-5$ & 1 & $\mathrm{~K}$ \\
$6-11$ & 2 & 1 \\
$12-16$ & 3 & 1 \\
$17-22$ & 6 & 2 \\
$23-27$ & 9 & 4 \\
$28-33$ & 17 & 8 \\
$34-38$ & 28 & 16 \\
$39-43$ & 16 & 18 \\
$44-49$ & 7 & 20 \\
$50-54$ & 6 & 18 \\
$55-60$ & 3 & 9 \\
$61-65$ & 2 & 2 \\
\hline
\end{tabular}

\subsubsection{Aplicação de dióxido de carbono $\left(\mathrm{CO}_{2}\right)$}

A aplicação de $\mathrm{CO}_{2}$ foi realizada entre $9 \mathrm{~h} 30$ e $11 \mathrm{~h} 30$ apenas em uma das estufas, pois na outra foi mantido o nível atmosférico de $\mathrm{CO}_{2}$. A aplicação de $\mathrm{CO}_{2}$ foi realizada junto com a água de irrigação, a cada dois dias, tendo por base a concentração na atmosfera definida inicialmente: 0 e $800 \mu \mathrm{mol} \mathrm{mol}^{-1} \mathrm{de}$ $\mathrm{CO}_{2}$, que correspondeu a acréscimos de 0 e $435 \mu \mathrm{mol} \mathrm{mol}^{-1}$ de $\mathrm{CO}_{2}$ na atmosfera. Essas concentrações foram estabelecidas considerando-se 0 ar como alvo. Em decorrência do resultado de um trabalho desenvolvido recentemente (Gomes, 2001), que demonstrou ser inviável considerar-se 0 ar como alvo para aplicação de $\mathrm{CO}_{2}$ via água de irrigação, essas concentrações foram transformadas para $\mathrm{kg}$ de $\mathrm{CO}_{2}$ por hectare, visando-se o solo como alvo. 
Para essa transformação foi necessário estabelecer-se um volume de controle, que foi definido como $122,5 \mathrm{~m}^{3}$ (área da estufa $=122,5 \mathrm{~m}^{2}$ e altura $=1,0 \mathrm{~m}$ ).

$\mathrm{O}$ sistema de aplicação de $\mathrm{CO}_{2}$ operou junto ao sistema de irrigação e era composto por um conjunto de injeção de $\mathrm{CO}_{2}$ (Figura 2) formado por um cilindro de 5,0kg, uma válvula reguladora de pressão, um manômetro, um fluxômetro (medidor de vazão), conexões de cobre e tubos de polietileno tipo cristal trançado de alta resistência à pressão. Como a pressão de injeção do $\mathrm{CO}_{2}$ do cilindro $\cong 50,0 \mathrm{kPa}$ ) na rede de irrigação era superior à do sistema de irrigação de cada estufa $\cong 10,0 \mathrm{kPa}), 0 \mathrm{CO}_{2}$ foi injetado diretamente nas linhas de irrigação da estufa que recebeu o tratamento com $\mathrm{CO}_{2}$. Após o ponto de injeção do $\mathrm{CO}_{2}$, foi instalado um hidrômetro, que além de medir o volume de água aplicado, auxiliou na mistura do $\mathrm{CO}_{2} \mathrm{com}$ a água de irrigação.

A aplicação do $\mathrm{CO}_{2}$ via água de irrigação foi iniciada 14 dias após o transplantio, quando as mudas já estavam estabelecidas, e terminou aos 15 dias antes da colheita, tendo sido realizada a calibração dos fluxômetros com antecedência.

A vazão e a dose do $\mathrm{CO}_{2}$ foram calculadas em função da concentração de $\mathrm{CO}_{2}$ desejada na água de irrigação, de acordo com o tratamento proposto, visando-se manter a concentração do gás constante na água, durante cada irrigação.

Com base nesses cálculos, foi definida a dose de $\mathrm{CO}_{2}$ aplicada via água de irrigação a cada dois dias: $8,52 \mathrm{~kg} \mathrm{ha}^{-1}$. Devido à baixa precisão do fluxômetro utilizado na aplicação, a quantidade de $\mathrm{CO}_{2}$ aplicada foi controlada por pesagem em cada aplicação e a distribuição real é apresentada na Figura 3. A quantidade total de $\mathrm{CO}_{2}$ aplicada durante o ciclo do melão foi de $301,8 \mathrm{~kg}$ $\mathrm{ha}^{-1}$, para uma quantidade meta de $281,8 \mathrm{~kg} \mathrm{ha}^{-1}$. 


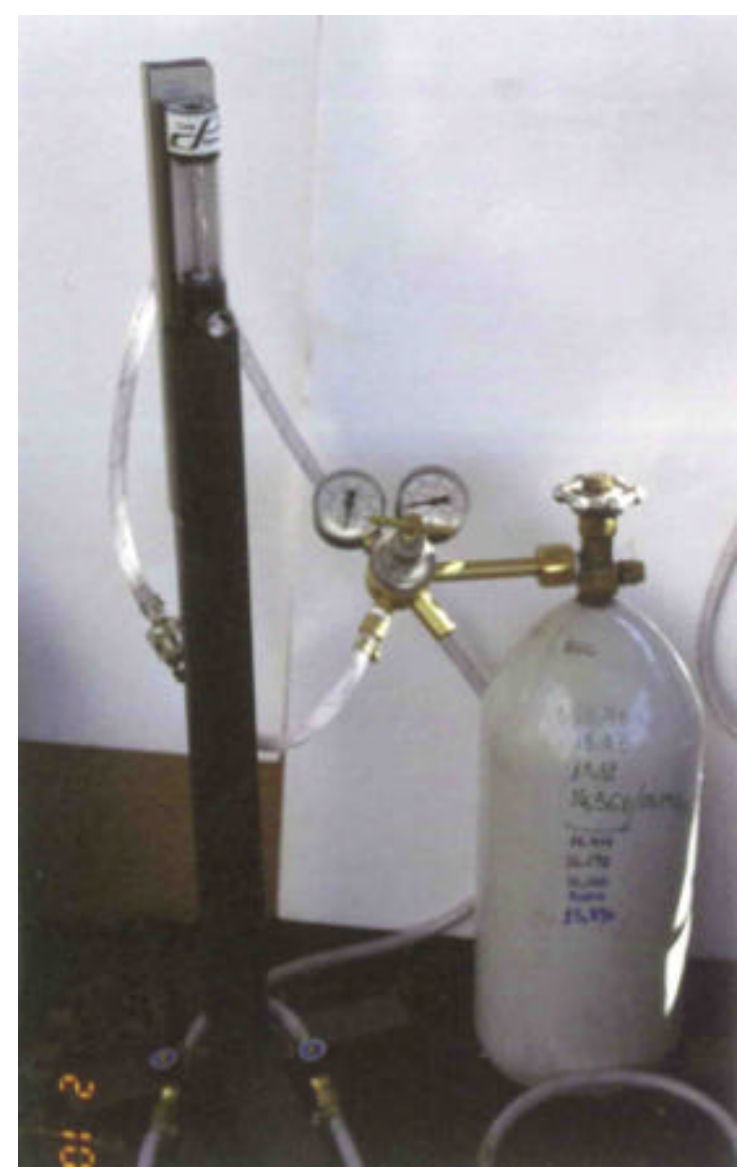

Figura 2 - Conjunto de injeção de $\mathrm{CO}_{2}$.

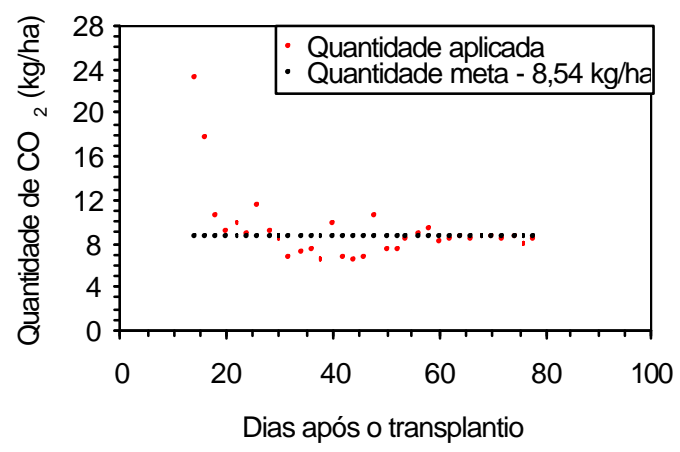

Figura 3 - Distribuição de $\mathrm{CO}_{2}$ durante o ciclo do meloeiro. 


\subsection{Obtenção dos resultados}

\subsubsection{Extração de nutrientes ao longo das épocas avaliadas}

\subsubsection{Coleta das plantas}

Para avaliar a extração de nutrientes pelo meloeiro rendilhado, foram definidas cinco épocas de coleta de material vegetativo: a) no transplantio (ODAT); b) no desenvolvimento vegetativo (15DAT); c) no início do florescimento (20DAT); d) no início da frutificação (52DAT); e) no meio da frutificação (72DAT) e f) no início da colheita dos frutos (97DAT).

Para obtenção dos resultados de massa de material seco e, posteriormente das extrações dos nutrientes foram utilizadas 20 mudas por repetição aos ODAT, foram coletadas duas plantas por parcela aos 15DAT e a partir dos 20DAT coletou-se uma planta por parcela.

Nas épocas 0 e 15DAT analisou a planta inteira, a partir da época 20DAT a planta foi subdividida em folhas, caule e ramos e a partir da época 52DAT, as flores e frutos também foram subdivididas.

As amostras foram levadas para o Laboratório de Nutrição Mineral de Plantas da USP/ESALQ, sendo devidamente lavadas em solução de água com detergente, água da torneira, água deionizada com $\mathrm{HCl}\left(0,01 \mathrm{~mol} \mathrm{~L}^{-1}\right)$ e por último somente com água deionizada. Após a remoção do excesso de água utilizada na lavagem por secagem ao ar, cada parte da planta foi colocada em saco de papel, identificada e levadas para secagem em estufa de circulação forçada de ar a $65-70^{\circ} \mathrm{C}$, até atingir peso constante, conforme recomendado por Sarruge \& Haag (1974). Depois de secas, as amostras foram pesadas em balança analítica, obtendo-se a massa de material seco de caule e ramos, folhas, flores e de cada fruto. A separação das plantas por órgãos foi feita para poder obter as extrações dos macronutrientes e micronutrientes pelos diferentes órgãos. 
Nas épocas 52, 72 e 97DAT, também foram avaliadas o comprimento e o diâmetro dos frutos, que foram obtidos em $(\mathrm{mm})$ com auxílio de um paquímetro digital.

\subsubsection{Análises químicas das plantas}

Após obtenção da massa de material seco, cada amostra passou pela moagem no moinho tipo Wiley, até as amostras passarem pela peneira de malha 20 mesh (1mm).

As análises químicas para a determinação dos teores de nutrientes presentes em cada órgão das plantas foram feitas nos extratos obtidos pela digestão sulfúrica (nitrogênio), nítrico-perclórica (fósforo, potássio, cálcio, magnésio, enxofre, cobre, ferro, manganês e zinco) e por via seca (boro) (Sarruge \& Haag, 1974).

O nitrogênio foi quantificado pelo método semi-micro Kjeldahl, fósforo e boro por colorimetria, potássio por fotometria de chama e cálcio, magnésio, enxofre, cobre, manganês, zinco e ferro por espectrofotometria de absorção atômica, conforme recomendado por Sarruge \& Haag (1974).

A partir das análises, foram obtidos os teores totais de nitrogênio, fósforo, potássio, cálcio, magnésio e enxofre em $\left(\mathrm{g} \mathrm{kg}^{-1}\right)$ e de boro, cobre, ferro, manganês e zinco em $\left(\mathrm{mg} \mathrm{kg}^{-1}\right)$. A quantidade dos nutrientes extraídos por cada parte da planta, foi obtida pela multiplicação do teor de cada nutriente pela massa seca do referente órgão (amostra).

\subsubsection{Produção de frutos}

Os frutos foram colhidos no início do mês de dezembro de 2001, a partir do $97^{\circ}$ dia após o transplantio, quando atingiram maturação fisiológica, brix em torno de $11^{\circ}$ brix, cor da casca acinzentada e rendilhamento nítido por toda a casca e ao redor do pedúnculo. Após a colheita, os frutos foram contados e 
pesados individualmente, obtendo-se, posteriormente, os resultados de produção total e comercial por planta e do peso médio dos frutos em cada tratamento. Foram considerados frutos comercializáveis aqueles com formato regular e com peso superior a 0,55 kg conforme Alves (2000) e metodologia utilizada por Gusmão (2001).

\subsection{Análise estatística}

Para a extração de nutrientes pelos órgãos do meloeiro, ao longo do ciclo, foi calculado o valor do erro padrão da média.

Para as variáveis: produção total e comercial de frutos, peso médio dos frutos, número de frutos, comprimento e diâmetro dos frutos, extração dos nutrientes pela parte aérea do meloeiro na colheita, realizou-se uma análise conjunta dos resultados das duas estufas (sistema convencional e sistema convencional com $\mathrm{CO}_{2}$ ), obtendo-se uma análise de variância pelo teste $\mathrm{F}$ e utilizou-se a análise de regressão para verificar o efeito das doses de potássio e o teste de Tukey para comparar o efeito da utilização do $\mathrm{CO}_{2}$.

$\mathrm{Na}$ análise conjunta, o efeito de $\mathrm{CO}_{2}$ está confundido com o efeito do experimento ou dos locais, porém, como houve homogeneização do solo, podese dizer que, se houve efeito significativo de experimento ele foi devido, principalmente, ao $\mathrm{CO}_{2}$. 


\section{RESULTADOS E DISCUSSÃO}

\subsection{Características das plantas coletadas em cada estádio fenológico}

O início do florescimento (20DAT) foi caracterizado quando ocorreu o aparecimento da primeira flor aberta na haste principal (caule).

$O$ aparecimento das flores masculinas no ramo principal ocorreu cerca de 18 dias após o transplantio e, as flores femininas, surgiram cerca de 20 dias depois, a partir do $11^{\circ}$ nó, região da planta considerada como mais apropriada para a produção.

$\mathrm{Na}$ Tabela 4 encontram-se os dados médios das características dos frutos das plantas coletadas, no período de frutificação (52 a 97DAT). Na colheita (97DAT), o diâmetro e o comprimento médio obtido estão semelhantes aos valores obtidos por Gusmão (2001) e Rizzo \& Braz (2001) ao avaliarem este mesmo híbrido.

Aos 16 dias após a polinização das flores localizadas no 11ํㅡó (56DAT) observou-se o início do rendilhamento dos frutos, sendo a colheita desses frutos realizada cerca de 40 dias após o início do rendilhamento, ou seja, 97DAT. O pegamento dos frutos foi considerado dentro do esperado, não sendo realizada a desbrota dos mesmos. 
Tabela 4. Resultados médios das características dos frutos das plantas coletadas no período de frutificação

\begin{tabular}{cccccc}
\hline DAT * $^{*}$ Rendilhamento & $\begin{array}{c}\text { Massa } \\
\text { verde } \\
\left(\mathrm{g} \mathrm{fruto}^{-1}\right)\end{array}$ & $\begin{array}{c}\text { Comprimento } \\
(\mathrm{mm})\end{array}$ & $\begin{array}{c}\text { Diâmetro } \\
(\mathrm{mm})\end{array}$ & $\begin{array}{c}\text { Relação } \\
\text { diâmetro/comprimento }\end{array}$ \\
\hline 52 & ausente & 37,92 & 47,47 & 29,81 & 0,61 \\
72 & início & 638,50 & 112,11 & 100,23 & 0,89 \\
97 & completo & 845,97 & 122,72 & 106,39 & 0,87
\end{tabular}

${ }^{*}$ DAT $=$ dias após o transplantio

Média das repetições dos tratamentos das duas estufas.

Pelos dados climáticos obtidos durante o cultivo do meloeiro rendilhado (Tabela 5) através de termohigrógrafos portáteis, instalados dentro das estufas, percebeu-se que as temperaturas encontradas estavam no intervalo considerado ideal para o desenvolvimento dessa cultura, segundo Sousa et al. (1999a).

Tabela 5. Valores médios de temperatura mínima, temperatura máxima, temperatura média e umidade relativa do ar (UR) obtidos nas estufas, nos diferentes períodos durante o cultivo do meloeiro rendilhado, a partir do transplantio das mudas

\begin{tabular}{ccccc}
\hline $\begin{array}{c}\text { Período } \\
(\mathrm{DAT})\end{array}$ & $\begin{array}{c}\text { Temperatura } \\
\text { mínima }\left({ }^{\circ} \mathrm{C}\right)\end{array}$ & $\begin{array}{c}\text { Temperatura } \\
\text { máxima }\left({ }^{\circ} \mathrm{C}\right)\end{array}$ & $\begin{array}{c}\text { Temperatura } \\
\text { média }\left({ }^{\circ} \mathrm{C}\right)\end{array}$ & UR $(\%)$ \\
\hline $0-15$ & 13,96 & 30,20 & 21,26 & 70 \\
$16-20$ & 15,03 & 31,34 & 21,88 & 70 \\
$21-52$ & 18,93 & 31,39 & 23,59 & 76 \\
$53-72$ & 18,22 & 30,41 & 23,85 & 75 \\
$73-97$ & 19,52 & 32,67 & 25,21 & 77 \\
\hline
\end{tabular}




\subsection{Produção de frutos}

As doses de potássio influenciaram a produção total de frutos, obtendose a maior produção $\left(1,8 \mathrm{~kg}\right.$ planta $^{-1}$, ou seja, $\left.6,16 \mathrm{~kg} \mathrm{~m}^{-2}\right)$ na dose de $300 \mathrm{~kg}$ ha $^{-1}$ de $\mathrm{K}_{2} \mathrm{O}$, ajustado por um modelo quadrático $(\mathrm{P}<0,01)$ (Tabela 6). $\mathrm{A}$ utilização de $\mathrm{CO}_{2}$ na água de irrigação aumentou a produção total e comercial de frutos $\left(\mathrm{kg} \mathrm{planta}^{-1}\right)$, o número de frutos comerciais por planta e o número de frutos comerciais por área $\left(\mathrm{m}^{2}\right) \quad(P<0,05)$ (Tabela 7). Não houve interação significativa, pelo teste $\mathrm{F}$ da análise de variância, entre as doses de potássio e os sistemas de cultivo (convencional e convencional com adição de $\mathrm{CO}_{2}$ ), para essas variáveis.

A produção total obtida neste trabalho foi semelhante às obtidas nos trabalhos de Maruyama et al. (2000), Gusmão (2001) e Gualberto et al. (2001) com este mesmo híbrido, que foram de $1,18 \mathrm{~kg}_{\text {planta }}^{-1} ; 1,82 \mathrm{~kg} \mathrm{planta}^{-1}$ e 5,99 $\mathrm{kg} \mathrm{m}^{-2}$, respectivamente. No entanto, os resultados de produção comercial obtidas nos dois sistemas de cultivo foram menores do que o encontrado por Gusmão (2001) (1,82 kg planta $\left.{ }^{-1}\right)$. Esse mesmo autor obteve 1,95 número de frutos comerciais por planta, resultado semelhante ao obtido no sistema com utilização de $\mathrm{CO}_{2}(1,98)$, porém maior do que o obtido no sistema convencional $(1,61)$. A dose de $300 \mathrm{~kg} \mathrm{ha}^{-1}$ de $\mathrm{K}_{2} \mathrm{O}$ foi a que proporcionou maior produção de frutos sendo a produtividade obtida próxima às obtidas por Sagiv et al. (1980) citados por Bar Yosef (1999) e Rincón Sánchez et al. (1998) que foram de 53,2 e $56 \mathrm{t} \mathrm{ha}^{-1}$ ao utilizarem as doses de 350 e $385 \mathrm{~kg} \mathrm{ha}^{-1}$ de potássio, respectivamente.

Para o peso médio do total de frutos houve interação significativa entre doses de potássio e os sistemas de cultivo $(\mathrm{P}<0,01)$. Para o sistema de cultivo convencional, o efeito de doses de potássio ajustou-se ao modelo linear $(P<0,01)$, enquanto que para o sistema com utilização de $\mathrm{CO}_{2}$, o efeito de doses de potássio ajustou-se ao modelo quadrático $(P<0,01)$, sendo a dose de 
$300 \mathrm{~kg} \mathrm{ha}^{-1}$ de $\mathrm{K}_{2} \mathrm{O}$ a que proporcionou maior peso médio dos frutos $(851,55 \mathrm{~g})$ (Tabela 6).

Para o peso médio dos frutos comerciais, a interação entre doses de potássio e os sistemas de cultivo foi significativa $(P<0,05)$. Para o sistema de cultivo convencional, as doses de potássio não influenciaram essa variável $(P>0,05)$, enquanto que para o sistema com a utilização de $\mathrm{CO}_{2}$ existiu efeito de doses de potássio sendo a dose de $300 \mathrm{~kg} \mathrm{ha}^{-1}$ de $\mathrm{K}_{2} \mathrm{O}$ a que proporcionou $\mathrm{o}$ maior peso médio dos frutos comerciais $(904,85 \mathrm{~g})$, verificado pelo modelo quadrático ajustado $(P<0,01)$ (Tabela 6$)$.

O peso médio dos frutos comerciais maior obtido com a dose de $300 \mathrm{~kg}$ ha $^{-1}$ de $\mathrm{K}_{2} \mathrm{O}$ com utilização de $\mathrm{CO}_{2}(904,85 \mathrm{~g})$, foi semelhante ao obtido por Gusmão (2001) (940,0 g). Considerando-se o total de frutos produzidos, o peso médio dos frutos $(851,55 \mathrm{~g})$ maior foi também proporcionado por $300 \mathrm{~kg} \mathrm{ha}^{-1}$ de $\mathrm{K}_{2} \mathrm{O}$, sendo inferior ao valor obtido por Gusmão (2001) (940,0 g).

Quanto ao diâmetro médio dos frutos, não houve efeito significativo $(P>0,05)$ para as doses de potássio e os sistemas de cultivo (Tabela 7$)$.

Para o comprimento médio dos frutos houve interação significativa entre doses de potássio e os sistemas de cultivo $(P<0,05)$. Para o sistema de cultivo convencional, as doses de potássio não influenciaram essa variável $(P<0,05)$. Para o sistema com a utilização de $\mathrm{CO}_{2}$, o efeito de doses de potássio ajustouse ao modelo quadrático $(P<0,01)$, sendo que a dose de $300 \mathrm{~kg} \mathrm{ha}^{-1}$ de $\mathrm{K}_{2} \mathrm{O}$ a que proporcionou maior comprimento médio dos frutos $(137,02 \mathrm{~mm}$ ) (Tabela 6). O comprimento médio dos frutos maior $(137,02 \mathrm{~mm}$, ou seja, $13,7 \mathrm{~cm})$ obtido na dose de $300 \mathrm{~kg} \mathrm{ha}^{-1}$ de $\mathrm{K}_{2} \mathrm{O}$, no sistema com utilização de $\mathrm{CO}_{2}$, foi superior aos obtidos por Rizzo \& Braz (2001) e por Gualberto et al. (2001) quando avaliaram produtividade desse mesmo meloeiro rendilhado também cultivado em ambiente protegido. 
Tabela 6. Equações ajustado para a produção total de frutos (PTF) em kg planta $^{-1}$, o peso médio do total de frutos (PMTF) em gramas, o peso médio dos frutos comerciais (PMFC) em gramas e o comprimento médio dos frutos (CMF) em milímetros, em função da aplicação de doses de potássio

\begin{tabular}{|c|c|c|c|c|}
\hline Variável & Sistema & Equação & $\mathrm{R}^{2}$ & $\mathrm{CV}(\%)$ \\
\hline \multirow[t]{2}{*}{ PTF } & Conv. e & $y=1,5416+0,0021 x-0,000002995 x^{2}$ & $0,34^{* *}$ & 10,27 \\
\hline & Conv. $+\mathrm{CO}_{2}$ & & & \\
\hline \multirow[t]{2}{*}{ PMTF } & Conv. & $y=807,4789-0,2513 x$ & $0,54^{* *}$ & 9,79 \\
\hline & Conv. $+\mathrm{CO}_{2}$ & $y=671,4653+1,0320 x-0,001439 x^{2}$ & $0,99^{* *}$ & 8,3 \\
\hline PMFC & Conv. $+\mathrm{CO}_{2}$ & $y=756,2180+0,8915 x-0,001323 x^{2}$ & $0,89^{* *}$ & 6,59 \\
\hline CMF & Conv. $+\mathrm{CO}_{2}$ & $y=107,5582+0,1579 x-0,000199 x^{2}$ & $0,82^{* *}$ & 5,92 \\
\hline
\end{tabular}

** significativo a $1 \%$ de probabilidade;

CV $(\%)$ = coeficiente de variação; $R^{2}=$ coeficiente de determinação;

PTF = produção total de frutos; PMTF = peso médio do total de frutos; PMFC = peso médio dos frutos comerciais; CMF = comprimento médio dos frutos.

Conv. = sistema convencional; Conv. $+\mathrm{CO}_{2}=$ sistema convencional com adição de $\mathrm{CO}_{2}$. 
Tabela 7. Média dos valores de produção total de frutos $\left(\mathrm{kg} \mathrm{planta}^{-1}\right)$, produção de frutos comerciais $\left(\mathrm{kg}\right.$ planta $\left.{ }^{-1}\right)$, número de frutos comerciais por planta, número de frutos comerciais por $\mathrm{m}^{2}$ e diâmetro dos frutos ( $\mathrm{mm}$ ) no sistema convencional e no sistema com adição de $\mathrm{CO}_{2}$ na água de irrigação

\begin{tabular}{lcc}
\hline & \multicolumn{2}{c}{ Sistema de cultivo } \\
Variável & Convencional & Convencional $+\mathrm{CO}_{2}$ \\
\hline Produção total & $1,66 \mathrm{a}$ & $1,85 \mathrm{~b}$ \\
Produção comercial & $1,34 \mathrm{a}$ & $1,61 \mathrm{~b}$ \\
Número de frutos comerciais por planta & $1,61 \mathrm{a}$ & $1,98 \mathrm{~b}$ \\
Número de frutos comerciais por $\mathrm{m}^{2}$ & $9,5 \mathrm{a}$ & $11,6 \mathrm{~b}$ \\
Diâmetro dos frutos & $102,49 \mathrm{a}$ & $110,30 \mathrm{a}$ \\
\hline Médias seguidas pela mesma letra, na linha, não diferem entre si, pelo teste de Tukey a $5 \%$ de \\
probabilidade.
\end{tabular}

Pelos resultados obtidos, verificou-se que a aplicação de $\mathrm{CO}_{2}$ via água de irrigação proporcionou aumentos da ordem de $23 \%$ no número de frutos comerciais e de $11 \%$ na produção total de frutos, ocorrendo cerca de $20 \%$ de aumento na produção comercial, $O$ aumento na produção de frutos foi também verificado pelos trabalhos que utilizaram a água carbonatada, desenvolvidos por Pinto (1997) para o melão cultivar Valenciano Amarelo, cultivado em ambiente protegido (27,3\%), por Araújo (2002) no trabalho com abobrinha, que obteve incremento no número de frutos e na produção, por Cararo (2000) e por Novero et al. (1991) na cultura do tomateiro, que obtiveram aumento de $7,6 \%$ e $9 \%$ na produtividade, respectivamente. Ibrahim (1992) e Mauney \& Hendrix (1988) também encontraram aumentos na produtividade de pepino e algodão, respectivamente. 


\subsection{Extração de nutrientes no sistema convencional}

\subsubsection{Nitrogênio}

Pela Figura 4 observa-se que a extração de nitrogênio acumulada nas folhas para os tratamentos que receberam $50 \mathrm{~kg} \mathrm{ha}^{-1} \mathrm{de} \mathrm{K}_{2} \mathrm{O}$ (T50), $150 \mathrm{~kg} \mathrm{ha}^{-1}$ de $\mathrm{K}_{2} \mathrm{O}(\mathrm{T} 150)$ e $300 \mathrm{~kg} \mathrm{ha}^{-1}$ de $\mathrm{K}_{2} \mathrm{O}$ (T300) foi crescente até os 52DAT e praticamente não se alterou nas demais épocas estudadas. Já para o tratamento que recebeu $600 \mathrm{~kg} \mathrm{ha}^{-1}$ de $\mathrm{K}_{2} \mathrm{O}$ (T600), a extração aumentou até os 72DAT e depois diminuiu.

No caule e ramos, para os tratamentos T50, T150 e T600 o aumento da extração foi nítido até os 52DAT e quase não se alterou até os 97DAT. Para o tratamento T300, as maiores extrações de nitrogênio ocorreram aos 52DAT e 97DAT. Nos frutos e flores, a extração aumentou até os 97DAT em todos tratamentos e essa mesma tendência ocorreu na parte aérea.

Aos 52DAT, todos tratamentos tiveram maior extração nas folhas e menor nos frutos e flores. Aos 72DAT em todos tratamentos, a maior extração foi acumulada nas folhas e a menor no caule e ramos. Nesse estádio fenológico, as extrações de nitrogênio acumulada nos frutos e flores variaram de $1.245,85$ a $2.027,24 \mathrm{mg}_{\text {planta }}{ }^{-1}$, valores próximos ao obtido por Canato et al. (2001) que foi de $1.350 \mathrm{mg}_{\text {planta }}{ }^{-1}$. No entanto, a extração pela parte aérea obtida no experimento $\left(3.879,07\right.$ a $\left.4.657,79 \mathrm{mg} \mathrm{planta}^{-1}\right)$ foi maior do que a obtido por esses autores (2.040 $\left.\mathrm{mg} \mathrm{planta}^{-1}\right)$.

Aos 97DAT, para os tratamentos T50, T150 e T600 a maior extração foi acumulada nos frutos e flores e a menor no caule e ramos, seguindo a mesma tendência obtida por Belfort (1985), Domingo Suárez (1991) e Rincón Sánchez et al. (1998). Para o tratamento T300, o que diferenciou foi que a extração acumulada nas folhas foi semelhante à dos frutos e flores. Os valores de extração obtidos no experimento pela parte aérea na colheita foram de 5.063,53 
a 5.946,19 $\mathrm{mg}_{\text {planta }}{ }^{-1}$, sendo esses valores bem menores do que o obtido por Belfort (1985) $\left(23.075,51 \mathrm{mg} \mathrm{planta}^{-1}\right)$.
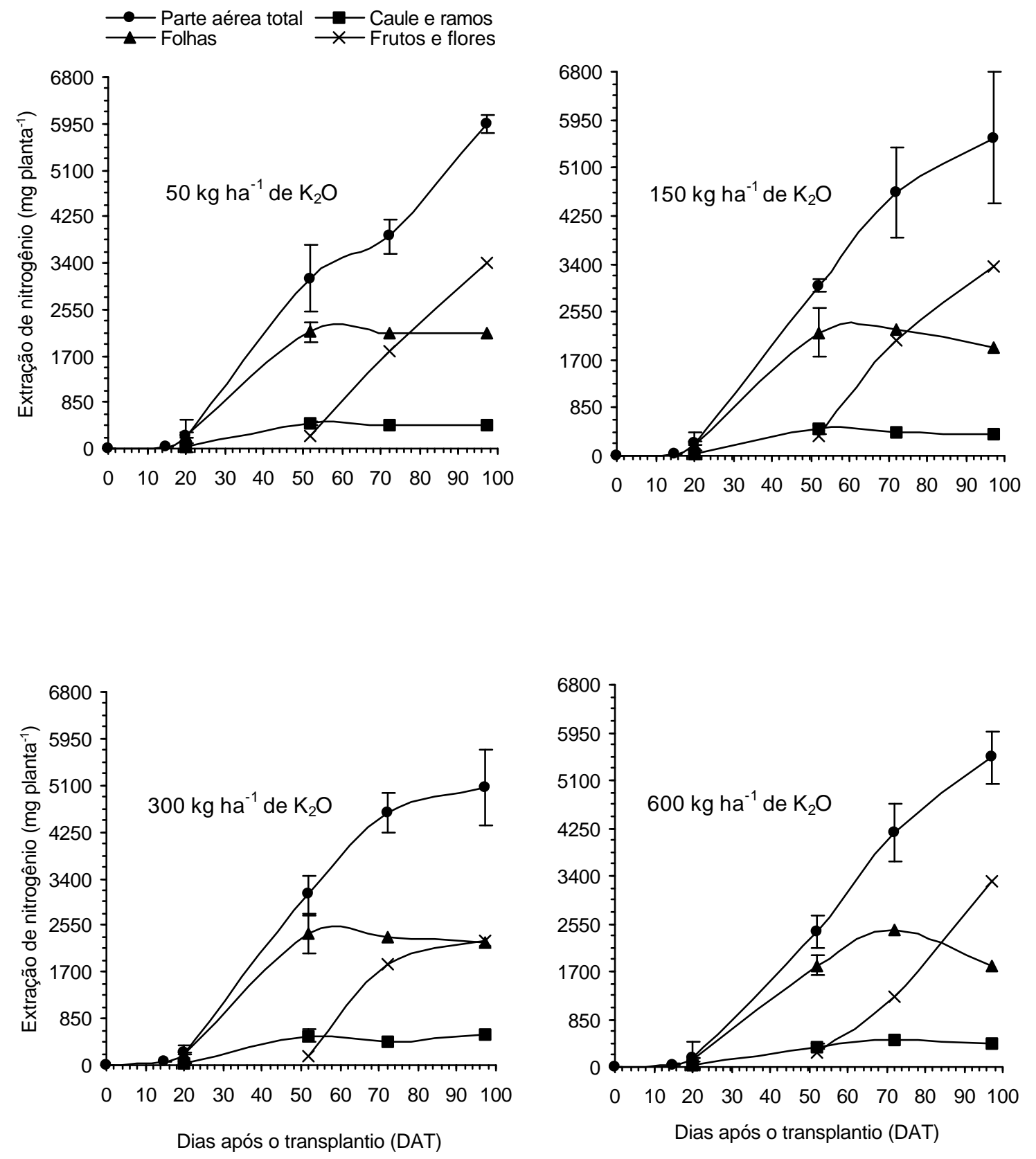

Figura 4 - Extração de nitrogênio acumulada nos órgãos do meloeiro ao longo do ciclo nas doses de potássio. As linhas verticais indicam o erro padrão da média. 


\subsubsection{Fósforo}

Na Figura 5 observa-se que a extração de fósforo acumulada nas folhas para o tratamento T150 aumentou até os 52DAT e se manteve até os 97DAT. Para os tratamentos T50 e T600, a extração aumentou até os 72DAT e para o tratamento T300, existiram duas épocas de maior extração, aos 52 e 97DAT.

No caule e ramos, em todos tratamentos, a extração aumentou até os 52DAT e diminuiu nas demais épocas avaliadas. Para os tratamentos T50, T150 e T600, a extração acumulada nos frutos e flores foi crescente até os 97DAT. Já para o tratamento T300 ocorreu aumento até os 72DAT e praticamente não se alterou aos 97DAT. A extração pela parte aérea foi crescente ao longo do ciclo em todos tratamentos.

Aos 52DAT, em todos tratamentos, a maior extração foi acumulada nas folhas e a menor nos frutos e flores. Aos 72DAT, nos tratamentos T50, T150 e T300, a maior extração foi acumulada nos frutos e flores e a menor no caule e ramos. No tratamento T600 a extração acumulada nas folhas foi semelhante à acumulada nos frutos e flores. Nesse estádio fenológico, as extrações acumuladas nos frutos e flores variaram de 244,17 a $350,90 \mathrm{mg} \mathrm{planta}^{-1}$, sendo esses valores bem próximos aos obtidos por Canato et al. (2001), que foi de $230 \mathrm{mg}$ planta $^{-1}$. Entretanto, os valores da extração de fósforo obtidos no experimento pela parte aérea $\left(568,55\right.$ a $\left.615,84 \mathrm{mg} \mathrm{planta}^{-1}\right)$ foram maiores do que o obtido por esses autores ( $310 \mathrm{mg}^{\text {planta }}{ }^{-1}$ ).

Aos 97DAT, em todos tratamentos, a maior extração acumulou nos frutos e flores e foi menor nos caule e ramos, seguindo a mesma tendência encontrada por Tyler \& Lorenz (1964), Belfort (1985) e Rincón Sánchez et al. (1998). Os valores de extração acumulada na parte aérea que variaram de 707,73 a $873,67 \mathrm{mg}$ planta $^{-1}$, foram bem menores do que o obtido por Belfort (1985) $\left(3.460,15 \mathrm{mg} \mathrm{planta}^{-1}\right)$ nessa mesma época. 

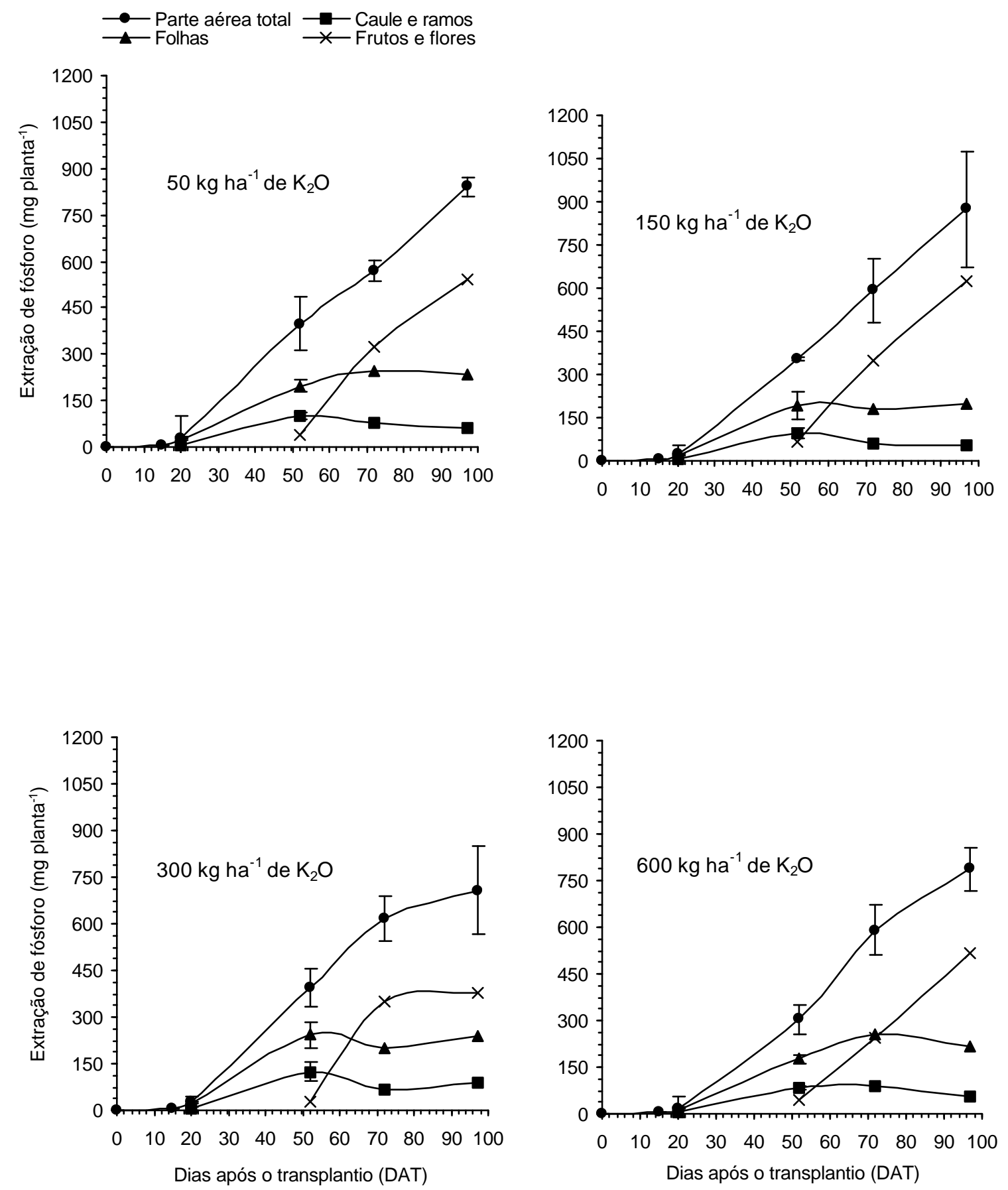

Figura 5 - Extração de fósforo acumulada nos órgãos do meloeiro ao longo do ciclo nas doses de potássio. As linhas verticais indicam o erro padrão da média. 


\subsubsection{Potássio}

Pela Figura 6 percebe-se que nas folhas, para os tratamentos T50, T150 e T300, a extração de potássio aumentou até os 52DAT e depois se manteve. Para o tratamento T600 esse aumento ocorreu até os 72DAT e depois diminuiu.

No caule e ramos, a extração acumulada foi semelhante em todos os tratamentos, aumentou até próximo dos 52DAT e praticamente não se alterou até os 97DAT.

Nos frutos e flores, apenas para o tratamento T600, a extração foi crescente até os 97DAT, pois para os demais tratamentos, o incremento da extração foi notável entre os 52 e 72DAT. A maior quantidade de potássio acumulado nos frutos e flores do tratamento T600 pode ser provavelmente um indicativo de que os teores na planta não influenciaram na produtividade, pois o tratamento T300 foi o que apresentou maior produção total de frutos.

Em todos os tratamentos, pelos resultados da parte aérea, percebe-se que a extração de potássio na planta provavelmente teve maior influência sobre o teor de potássio na massa de material seco dos frutos e flores. Aos 52DAT, para todos tratamentos, a maior extração acumulou nas folhas e foi menor nos frutos e flores.

Aos 72DAT, nos tratamentos T50 e T150, a maior extração de potássio acumulou nos frutos e flores, enquanto que para o tratamento T300 foi maior nas folhas e menor no caule e ramos. No tratamento T600, a maior extração também acumulou nas folhas, e a do caule e ramos foi semelhante à dos frutos e flores. Os valores de extração acumulada nos frutos e flores nesse estádio fenológico foram semelhantes aos encontrados por Canato et al. (2001), porém, o valor de extração acumulada na parte aérea obtido por esses autores (4.710 mg planta $^{-1}$ ) foi menor que os valores obtidos nos tratamentos deste experimento que foram de 6.180 a $9.210 \mathrm{mg} \mathrm{planta}^{-1}$.

Aos 97DAT, nos tratamentos T50 e T150, a extração acumulada nas folhas foi semelhante a dos frutos e flores. Para o tratamento T300, a extração 
foi maior nas folhas e a do caule e ramos foi semelhante à dos frutos e flores. No tratamento T600, a maior extração acumulou nos frutos e flores e foi menor no caule e ramos. A grande quantidade de potássio acumulada nos frutos, principalmente para os tratamentos T50, T150 e T600 seguiu a mesma tendência encontrada por Belfort (1985) e Rincón Sánchez et al. (1998).

A redução da extração de potássio acumulada nos frutos e flores ao longo das épocas avaliadas observada no tratamento T300, seguiu o mesmo resultado obtido por Tyler \& Lorenz (1964).

$\mathrm{Na}$ colheita, Belfort (1985) encontrou valor bem maior $(28.904,77 \mathrm{mg}$ planta $^{-1}$ ) de extração de potássio pela parte aérea do que os valores obtidos neste experimento que variaram de $6.178,71$ a $9.211,91 \mathrm{mg} \mathrm{planta}^{-1}$ sendo maior no tratamento T600. 

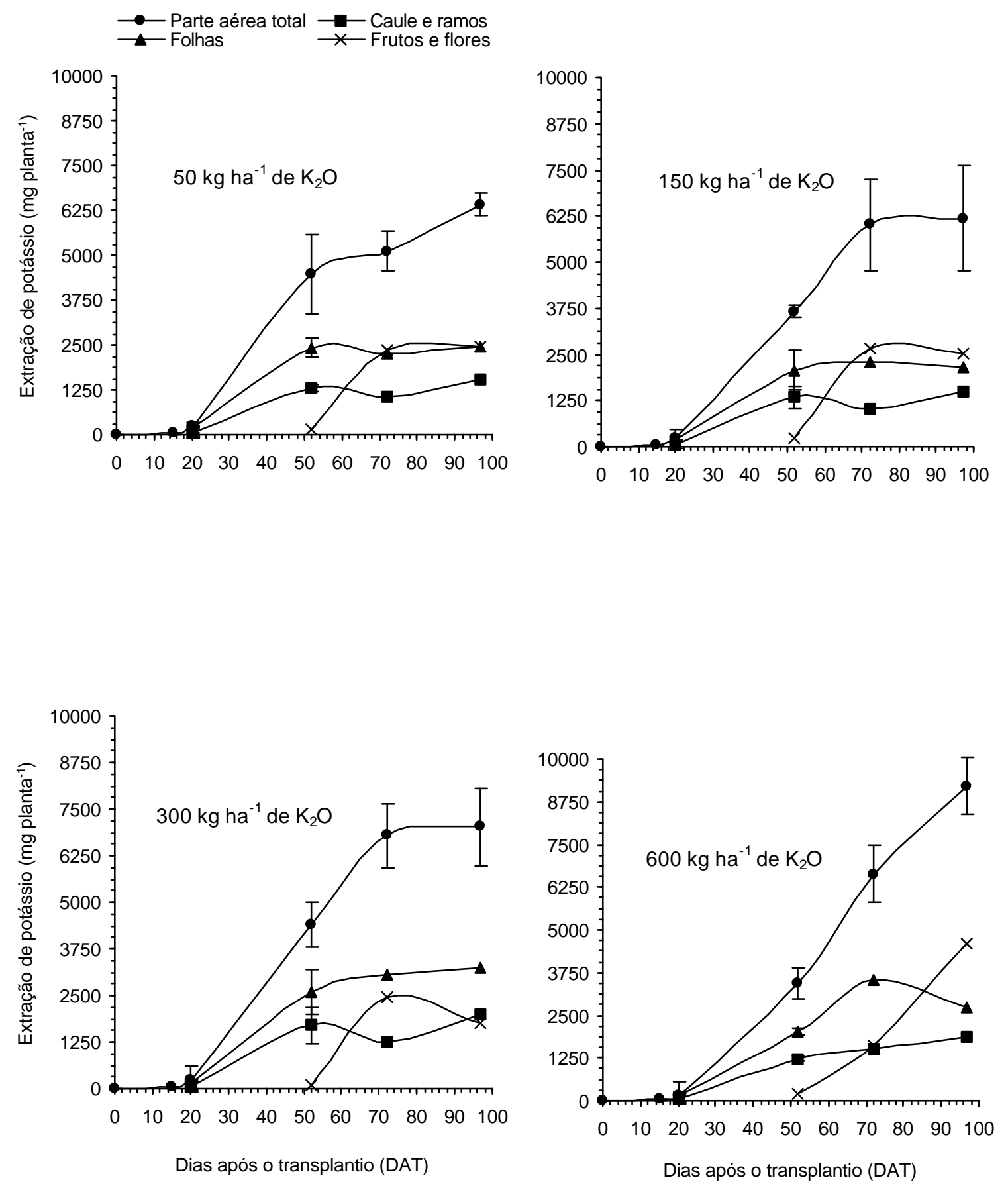

Figura 6 - Extração de potássio acumulada nos órgãos do meloeiro ao longo do ciclo nas doses de potássio. As linhas verticais indicam o erro padrão da média. 


\subsubsection{Cálcio}

A extração de cálcio (Figura 7) acumulada nas folhas aumentou até os 97DAT em todos tratamentos. Essa mesma tendência ocorreu para o caule e ramos, porém em menor intensidade.

Nos frutos e flores, para todos tratamentos, o acúmulo aumentou até os 72DAT e teve uma pequena redução aos 97DAT. Esses resultados coincidem com Bernadac et al. (1996) que verificaram que $80 \%$ da acumulação do cálcio ocorreu durante a primeira metade do desenvolvimento dos frutos.

A extração acumulada na parte aérea seguiu a mesma tendência da extração acumulada nas folhas, provavelmente devido à grande influência do teor de cálcio na massa de material seco das folhas em todos tratamentos.

Aos 52DAT, todos tratamentos tiveram maior extração acumulada nas folhas e menor nos frutos e flores. Aos 72 DAT, para os tratamentos T50, T300 e T600, a maior extração continuou acumulando nas folhas e a extração pelo caule e ramos foi semelhante à dos frutos e flores. Para o tratamento T150, a diferença foi que o valor de extração de cálcio acumulada no caule e ramos foi menor do que nos frutos e flores. Nesse estádio fenológico, os valores de extração em $\mathrm{mg}$ planta $^{-1}$ acumulada nos frutos e flores foram de 227,99 a 313,61 e na parte aérea variaram de 3.382,58 a 4.221,99, sendo próximos aos obtidos por Canato et al. (2001) que foram de 230 e $3720 \mathrm{mg}^{\text {planta }}{ }^{-1}$ nos frutos e flores e na parte aérea respectivamente.

Aos 97DAT, em todos tratamentos, a maior extração acumulou nas folhas e a menor nos frutos e flores seguindo a mesma tendência encontrada por Belfort (1985) e Rincón Sánchez et al.(1998). As extrações acumuladas na parte aérea variaram de 4.901,30 a 5.559,96 mg planta ${ }^{-1}$, sendo os valores bem menores do que o obtido por Belfort (1985) (12.742,04 mg planta ${ }^{-1}$ ). 

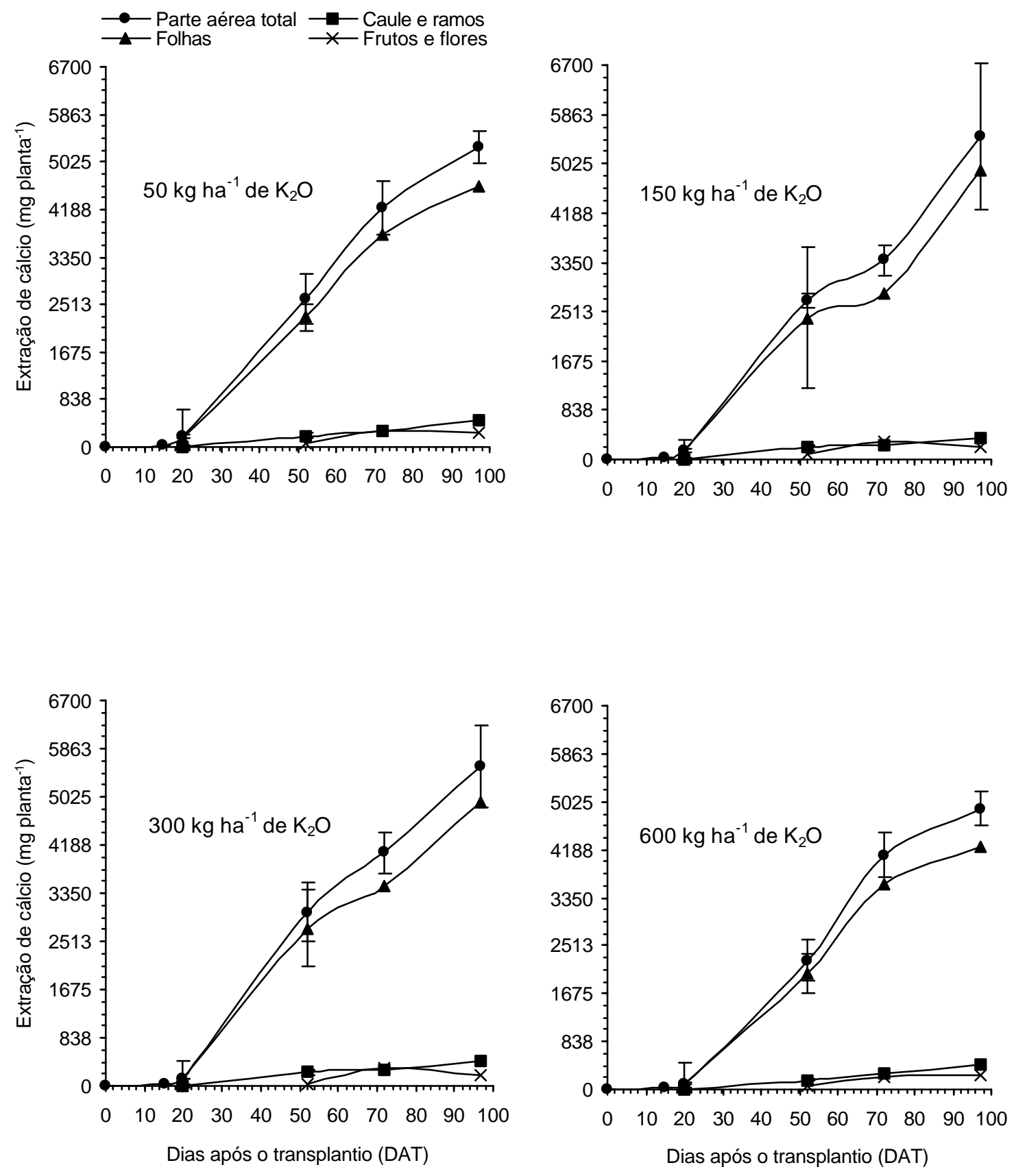

Figura 7 - Extração de cálcio acumulado nos órgãos do meloeiro ao longo do ciclo nas doses de potássio. As linhas verticais indicam o erro padrão da média. 


\subsubsection{Magnésio}

Na Figura 8 observa-se que nas folhas, em todos tratamentos o maior acúmulo de magnésio ocorreu aos 97DAT.

No caule e ramos, para todos tratamentos, os maiores acúmulos ocorreram aos 52 e 97DAT e nos frutos e flores a tendência da extração foi crescente, sendo maior aos 97DAT.

Aos 52DAT, todos tratamentos apresentaram maior acúmulo nas folhas e a menor nos frutos e flores. Aos 72DAT, os menores valores de extração acumularam no caule e ramos e a maior continuou nas folhas em todos tratamentos. Os valores de extração acumulada nos frutos e flores obtidos nesse estádio fenológico variaram de 137,19 a 260,40 mg planta ${ }^{-1}$, sendo próximos ao obtido por Canato et al. (2001) que foi de $170 \mathrm{mg} \mathrm{planta}^{-1}$. Mas, os valores de extração obtidos para a parte aérea (974,97 a 1.248,18 $\mathrm{mg} \mathrm{planta}^{-1}$ ) foram maiores do que o encontrado por esses autores que foi de $670 \mathrm{mg}$ planta $^{-1}$.

Aos 97DAT em todos tratamentos, a menor extração de magnésio acumulou no caule e ramos e a maior continuou nas folhas, resultados semelhante aos obtidos por Belfort (1985) e Rincón Sánchez et al. (1998). Nessa época, os valores de extração de magnésio acumulados na parte aérea total variaram de $1.846,23$ a $2.058,71 \mathrm{mg} \mathrm{planta}^{-1}$ (T300), sendo os valores menores do que o obtido por Belfort (1985) (5.548,82 $\left.\mathrm{mg} \mathrm{planta}^{-1}\right)$. 

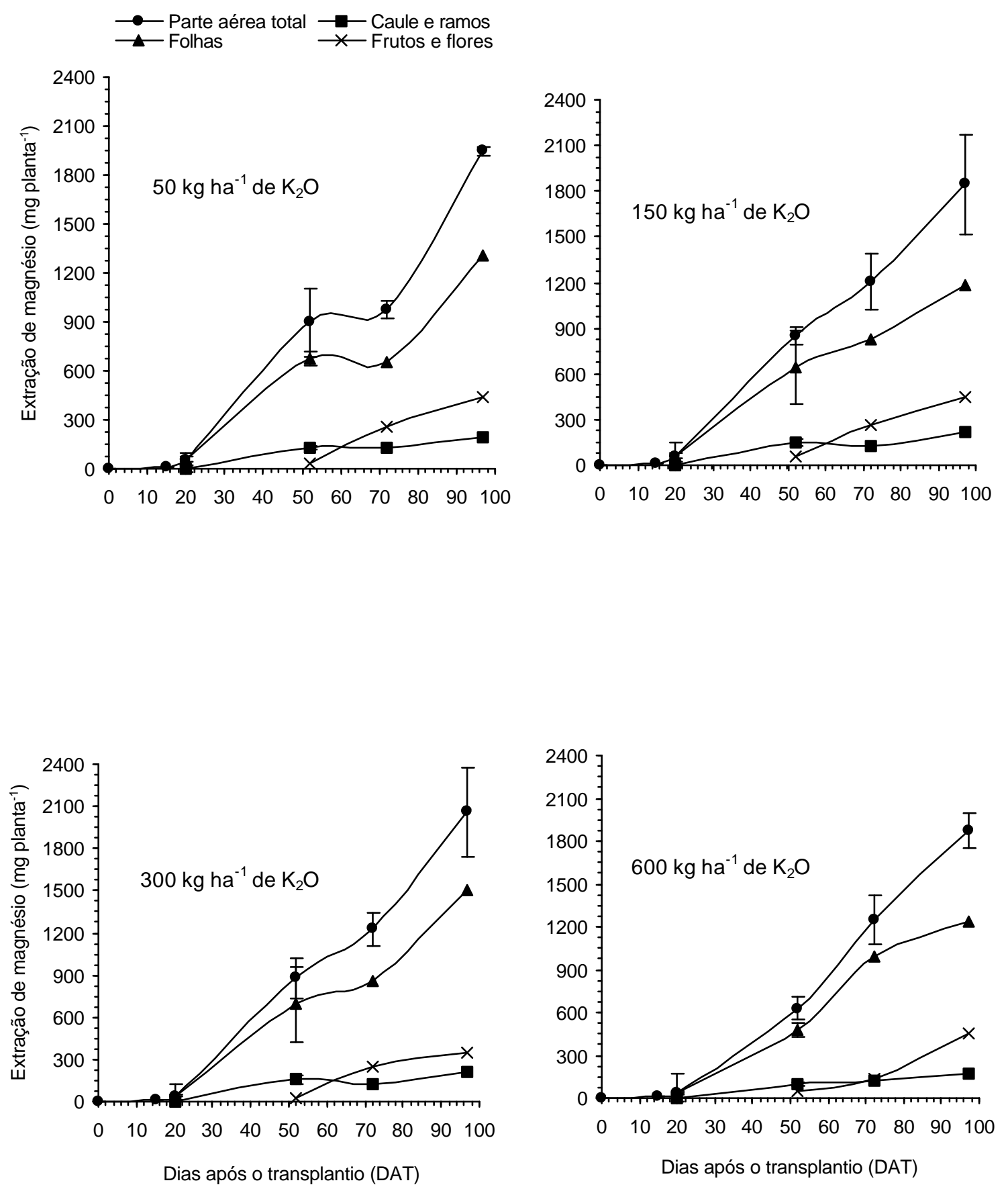

Figura 8 - Extração de magnésio acumulada nos órgãos do meloeiro ao longo do ciclo nas doses de potássio. As linhas verticais indicam o erro padrão da média. 


\subsubsection{Enxofre}

Nas folhas, a tendência da extração de enxofre (Figura 9) foi crescente até os 97DAT em todos tratamentos. No caule e ramos, nos frutos e flores, o acúmulo aumentou até os 97DAT em todos tratamentos. Desse mesmo modo, também ocorreu na parte aérea.

Aos 52DAT a maior extração foi obtida nas folhas e os menores valores ocorreram nos frutos e flores para todos tratamentos. Aos 72DAT para os tratamentos T50, T150 e T300, os menores valores de extração foram encontrados no caule e ramos, e para o tratamento T600 nos frutos e flores, no entanto, para todos tratamentos a maior extração continuou nas folhas. Os valores de extração obtidos nesse estádio fenológico nos frutos e flores foram semelhantes aos encontrados por Canato et al. (2001), porém os valores de extração obtidos na parte aérea $\left(944,15\right.$ a $\left.1.016,62 \mathrm{mg} \mathrm{planta}^{-1}\right)$ foram maiores do que o obtido por esses autores que foi de $160 \mathrm{mg} \mathrm{planta}^{-1}$.

Aos 97DAT para os tratamentos T50, T150 e T600, a menor extração de enxofre ocorreu no caule e ramos e, a maior nas folhas, resultados semelhantes aos obtidos por Belfort (1985). No tratamento T300, o que diferenciou foi que a extração acumulada no caule e ramos foi semelhante a dos frutos e flores. As extrações acumuladas na parte aérea (1.300,58 a 1.439,72 $\left.\mathrm{mg} \mathrm{planta}^{-1}\right)$ foram semelhantes ao resultado de Belfort (1985) (1.587,17 mg planta $\left.^{-1}\right)$. 

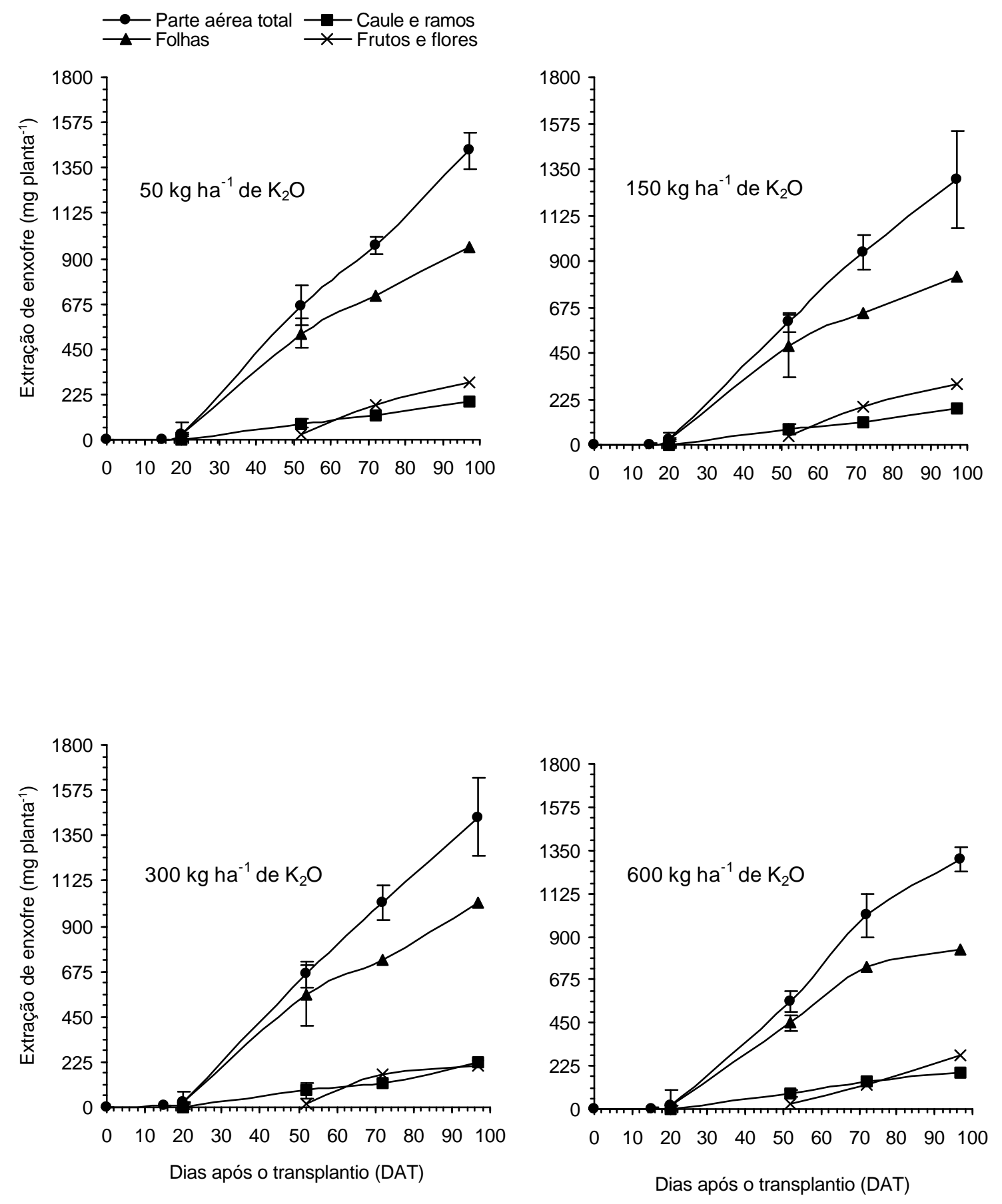

Figura 9 - Extração de enxofre acumulada nos órgãos do meloeiro ao longo do ciclo nas doses de potássio. As linhas verticais indicam o erro padrão da média. 


\subsubsection{Boro}

A Figura 10 representa a extração de boro. Nas folhas, para os tratamentos T50 e T600 ocorreram aumentos das extrações até os 97DAT. Para os tratamentos T150 e T300, as maiores extrações ocorreram aos 52 e 97DAT. No caule e ramos, em todos tratamentos, a maior extração foi até os 52DAT e depois reduziu com o tempo.

Nos frutos e flores, para os tratamentos T50, T150 e T600, a extração de boro foi crescente em todas as épocas avaliadas, coincidindo com os resultados obtidos por Belfort (1985). Para o T300 a maior extração ocorreu aos 72DAT e praticamente não se alterou aos 97DAT. Na parte aérea, a extração aumentou até os 97DAT para todos tratamentos.

Aos 52DAT, todos tratamentos tiveram extração maior de boro acumulada nas folhas e menor acumulada nos frutos e flores. Aos 72DAT, para os tratamentos T50, T150 e T300, a menor extração ocorreu no caule e ramos e a extração pelas folhas foi semelhante à dos frutos e flores. Para o tratamento T600, continuou sendo menor no caule e ramos, mas foi maior nas folhas.

Aos 97DAT, a extração foi menor no caule e ramos em todos tratamentos. No entanto, para os tratamentos T50 e T600, a extração foi maior nos frutos e flores e para o tratamento T300 nas folhas. No tratamento T150 a extração pelas folhas foi semelhante ao acumulada nos frutos e flores. Os valores de extração de boro pela parte aérea nessa época variaram de 5.763,04 a $6.972,33 \mu$ planta $^{-1}$, sendo inferiores ao obtido por Belfort (1985) que foi de $33.833 \mu$ g planta $^{-1}$. 

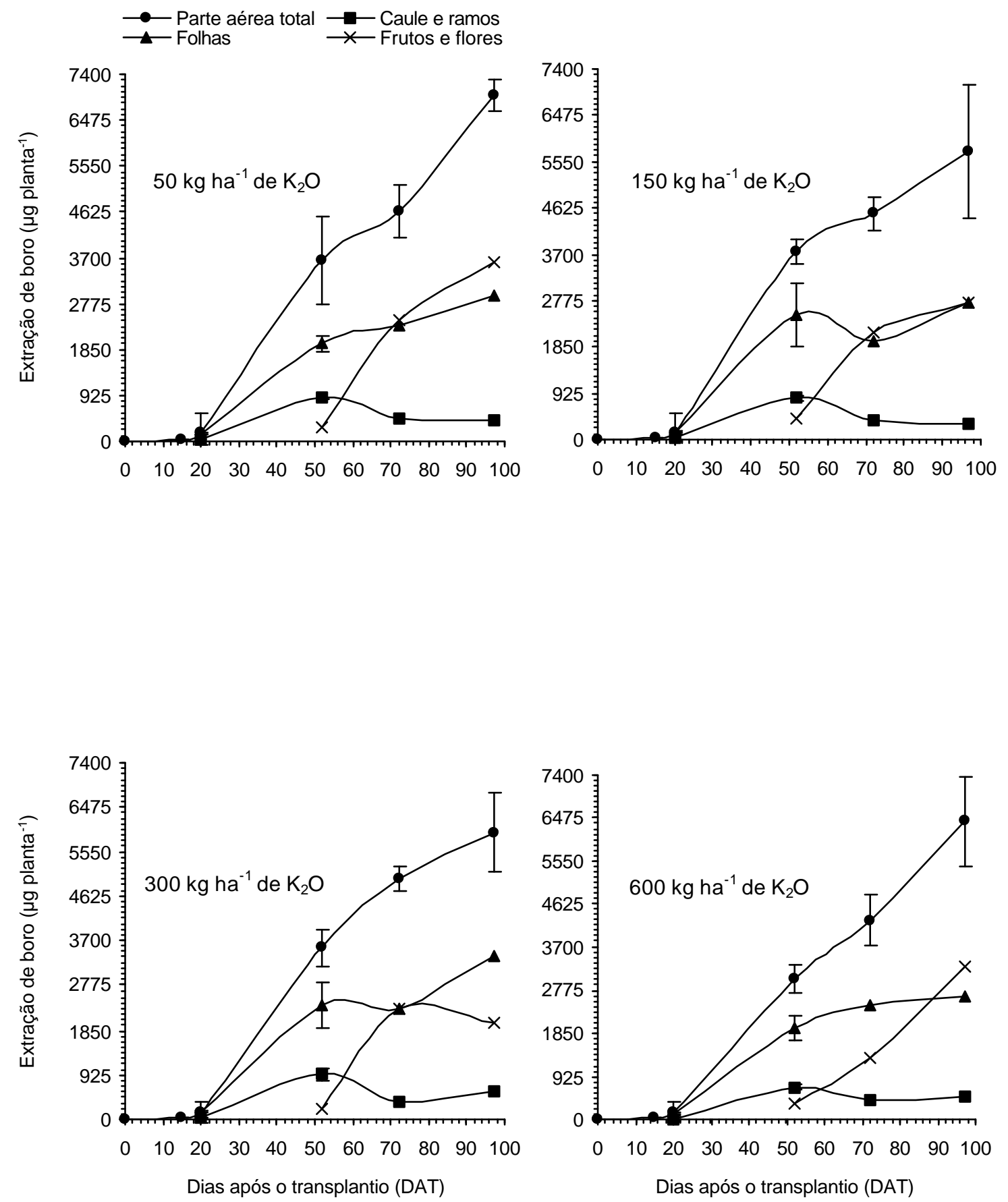

Figura 10 - Extração de boro acumulada nos órgãos do meloeiro ao longo do ciclo nas doses de potássio. As linhas verticais indicam o erro padrão da média. 


\subsubsection{Cobre}

Observa-se que nas folhas, a extração de cobre (Figura 11) para os tratamentos T50, T300 e T600 aumentou até os 97DAT. Para o tratamento T150, a extração aumentou até os 72DAT e diminuiu aos 97DAT. No caule e ramos e nos frutos e flores, a tendência da extração foi crescente até os 97DAT, para todos tratamentos.

A extração pela parte aérea seguiu a mesma tendência da extração pelo caule e ramos, foi crescente até os 97DAT e provavelmente teve maior influência do teor de cobre acumulado na massa de material seco do caule e ramos.

Aos 52DAT, a maior extração ocorreu nas folhas e a menor nos frutos e flores. Aos 72DAT, para os tratamentos T50, T300 e T600, os maiores valores de extração foram encontrados no caule e ramos e os menores nos frutos e flores. Para o tratamento T150, o que diferenciou foi que a maior extração ocorreu nas folhas. Os valores de extração de cobre acumulada nessa época nos frutos e flores, que variaram de 519,08 a $934,75 \mu$ planta $^{-1}$ e na parte aérea $\left(4.274,20\right.$ a $7.264,78 \mu$ p planta $\left.^{-1}\right)$ foram maiores do que os obtidos por Canato et al. (2001) que foram de 650 e $1.040 \mu$ planta $^{-1}$ nos frutos e flores e na parte aérea, respectivamente.

Aos 97DAT, a maior extração de cobre ocorreu no caule e ramos e a menor nos frutos e flores, em todos tratamentos. Esse resultado foi diferente do encontrado por Belfort (1985), nessa mesma época, que verificou maior extração acumulada nas folhas. As extrações acumuladas na parte aérea obtidas no experimento foram de 7.613,83 a 10.785,45 $\mu$ g planta $^{-1}$, sendo esses valores menores do que o obtido por esse autor $\left(172.390 \mathrm{\mu g} \mathrm{planta}^{-1}\right)$. 

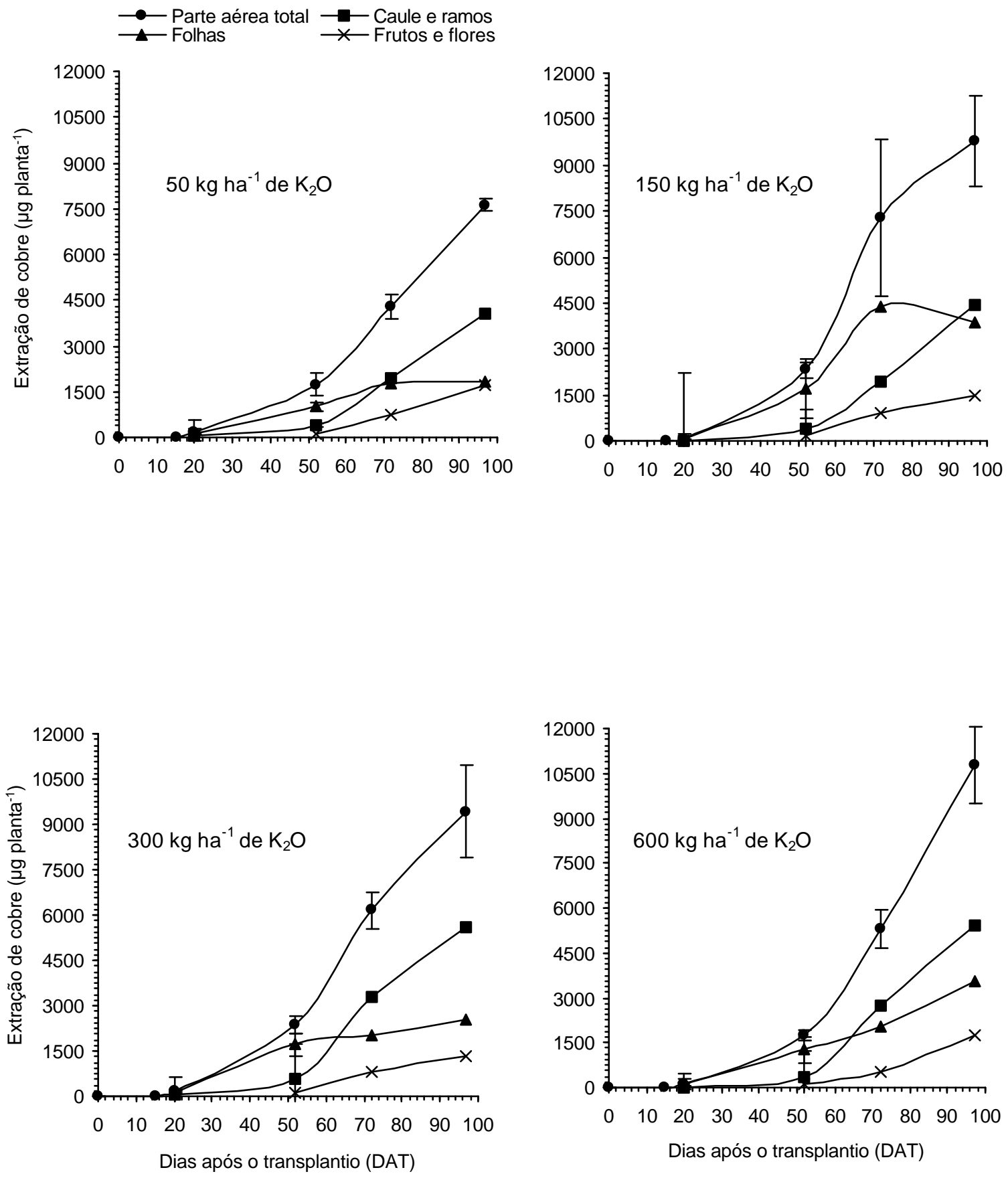

Figura 11 - Extração de cobre acumulada nos órgãos do meloeiro ao longo do ciclo nas doses de potássio. As linhas verticais indicam o erro padrão da média. 


\subsubsection{Ferro}

Pela Figura 12 observa-se que a extração de ferro acumulada nas folhas foi crescente ao longo das épocas avaliadas, em todos tratamentos. No caule e ramos as maiores extrações ocorreram aos 52 e 97DAT. Nos frutos e flores, todos tratamentos tiveram aumento da extração até os 97DAT.

A extração desse nutriente acumulada na parte aérea seguiu a mesma tendência da extração acumulada nas folhas, provavelmente, teve maior influência pelo teor de ferro na massa de material seco das folhas.

Aos 52DAT, para todos tratamentos, a maior extração ocorreu nas folhas e a menor nos frutos e flores. Aos 72 e 97DAT, para todos tratamentos, a menor extração ocorreu no caule e ramos e a maior nas folhas, sendo que aos 72DAT, os valores da extração acumulada nos frutos e flores $(3.492,53$ a $5.431,15 \mu$ planta $^{-1}$ ) foram próximos dos obtidos por Canato et al. (2001) $\left(5.670 \mu \mathrm{g}\right.$ planta $\left.^{-1}\right)$. Já as extrações pela parte aérea $(27.290,09$ a 33.694,43 $\mu \mathrm{g}$ planta $^{-1}$ ) foram menores do que a obtida por esses autores $\left(66.440 \mu \mathrm{g} \mathrm{planta}^{-1}\right)$.

Aos 97DAT, a seqüência da extração obtida diferiu da encontrada por Belfort (1985), que obteve menor extração de ferro pelos frutos e flores. A extração pela parte aérea obtida por esse autor $\left(172.394 \mu\right.$ planta $\left.^{-1}\right)$ foi maior do que as obtidas neste experimento (55.656,57 a 61.353,37 $\mu$ g planta $\left.^{-1}\right)$. 

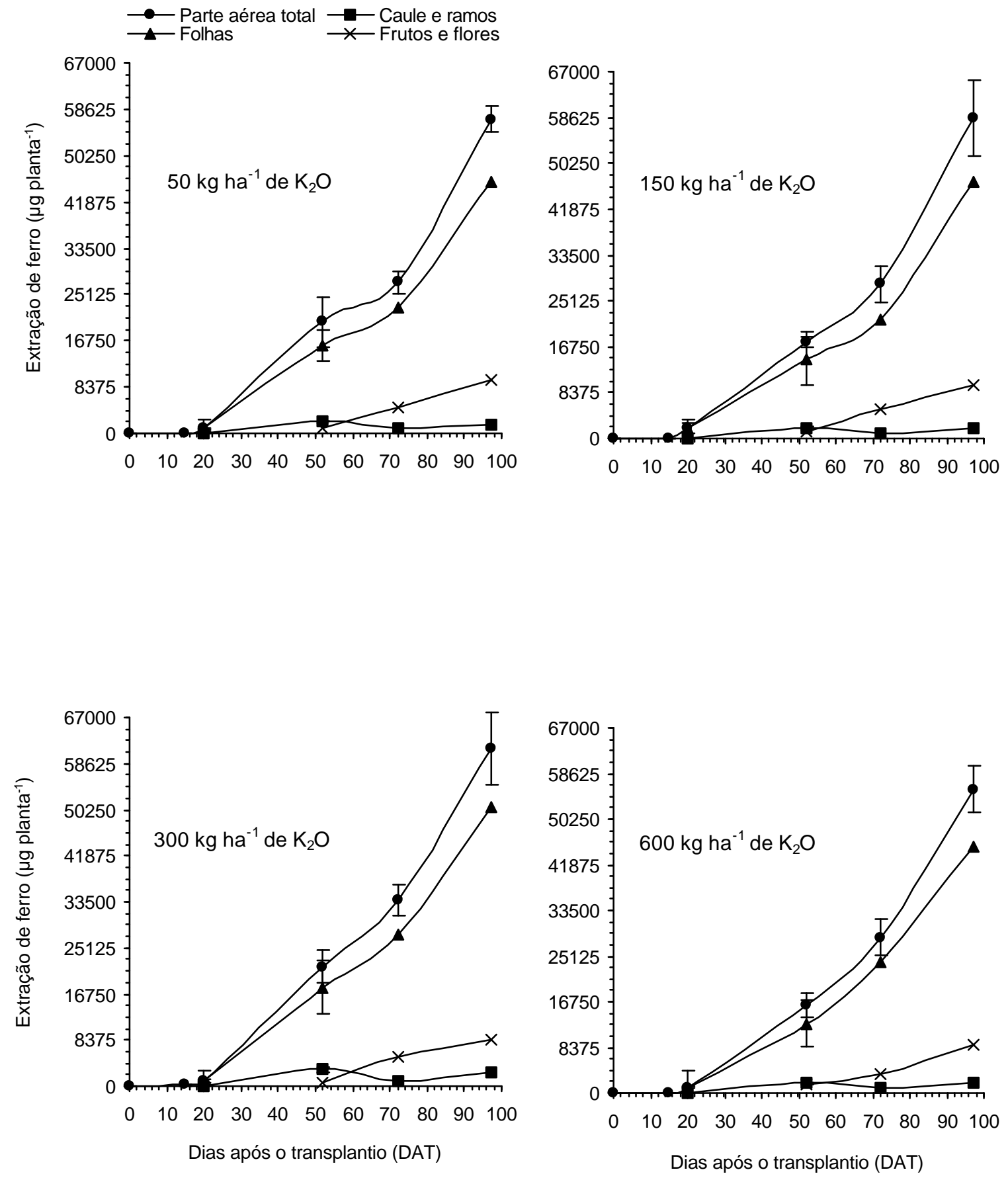

Figura 12 - Extração de ferro acumulada nos órgãos do meloeiro ao longo do ciclo nas doses de potássio. As linhas verticais indicam o erro padrão da média. 


\subsubsection{Manganês}

A extração de manganês (Figura 13) acumulada nas folhas, no caule e ramos e nos frutos e nas flores aumentou até os 97DAT, em todos tratamentos.

A extração acumulada na parte aérea seguiu a mesma tendência que a acumulada nas folhas, pois, provavelmente o teor de manganês na massa de material seco das folhas foi a que mais influenciou essa extração.

Aos 52DAT, a maior extração ocorreu nas folhas e a menor nos frutos e flores, para todos tratamentos. Aos 72DAT, a extração foi menor no caule e ramos e maior nas folhas. As extrações em $\mu \mathrm{g}$ planta $^{-1}$ acumuladas nos frutos e flores, nesse estádio fenológico, foram de 1.656,91 a 2.454,00 e na parte aérea $(13.000,94$ a 17.210,82), sendo esses valores maiores do que os obtidos por Canato et al. (2001) que foram de 890 e $4.200 \mu$ planta $^{-1}$.

Aos 97DAT, para os tratamentos T50, T150 e T600, a extração foi menor no caule e ramos e maior nas folhas. Para o tratamento T300, o que diferenciou foi que a menor extração que acumulou nos frutos e flores. Essa maior extração pelas folhas seguiu a mesma grandeza obtida por Belfort (1985), que obteve uma extração pela parte aérea de $109.952 \mu \mathrm{g}$ planta $^{-1}$, valor bem acima dos obtidos neste experimento $\left(21.364,49\right.$ a 29.306,24 $\left.\mathrm{mg}_{\text {planta }}{ }^{-1}\right)$ nessa mesma época. 

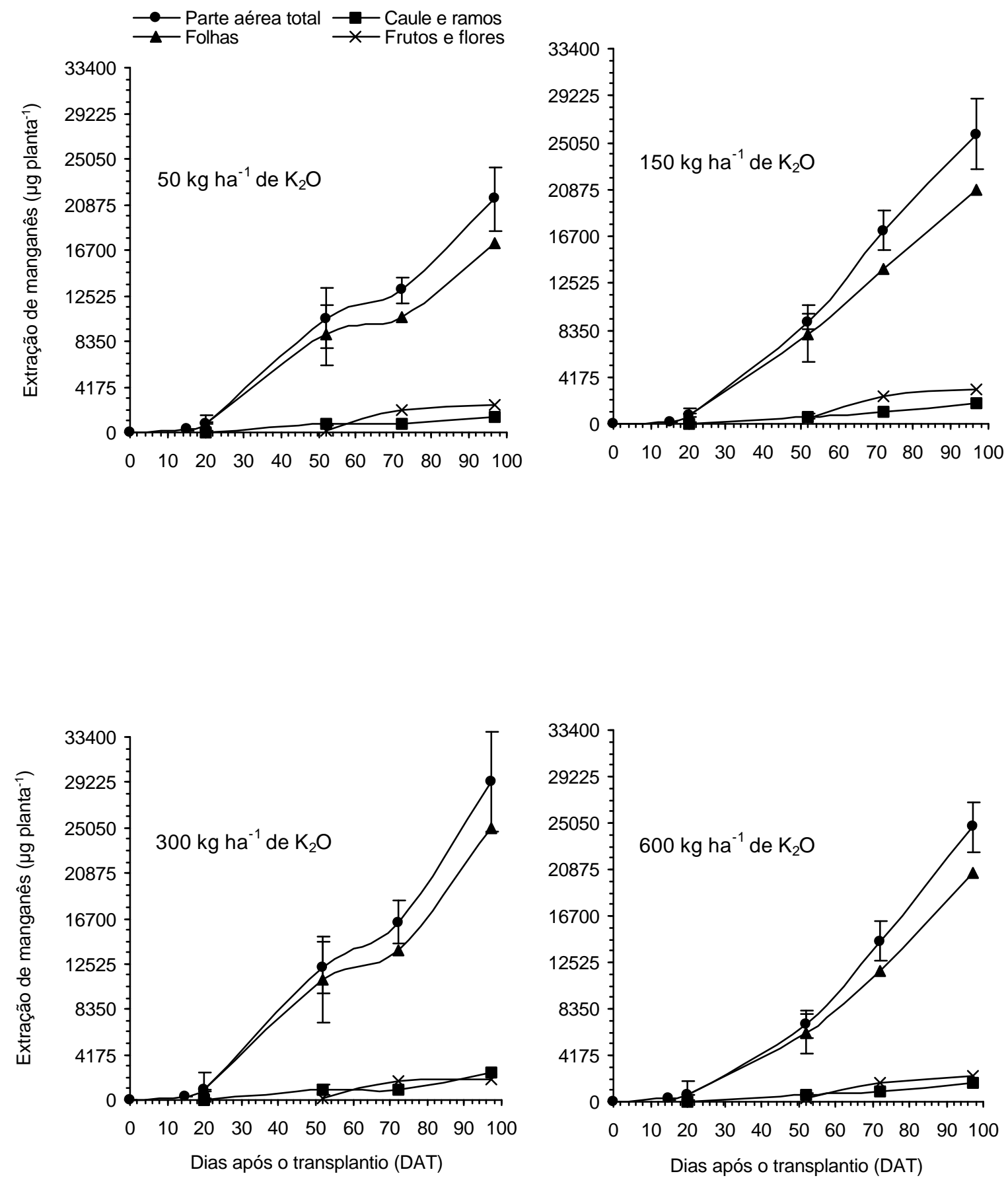

Figura 13 - Extração de manganês acumulado nos órgãos do meloeiro ao longo do ciclo nas doses de potássio. As linhas verticais indicam o erro padrão da média. 


\subsubsection{Zinco}

Pela Figura 14 observa-se que para os tratamentos T50 e T300, as maiores extrações de zinco acumulada nas folhas ocorreram aos 52 e 97DAT. Enquanto que para os tratamentos T150 e T600, a extração aumentou até os 72DAT e depois diminuiu.

No caule e ramos, para os tratamentos T50 e T150, a extração de zinco aumentou até os 52DAT e depois diminuiu. Para o tratamento T300, a extração foi maior aos 52 e aos 97DAT. No tratamento T600, a extração aumentou até os 72DAT e depois reduziu. Em todos tratamentos, a tendência da extração pelos frutos e flores foi crescente até os 97DAT.

Aos 52DAT, a extração foi maior nas folhas e menor nos frutos e flores, para todos tratamentos. Aos 72DAT, para os tratamentos T150, T300 e T600, a menor extração acumulou no caule e ramos e a menor nas folhas. No tratamento T50, a diferença foi que a extração pelas folhas foi semelhante à acumulada nos frutos e flores. As extrações em $\mu \mathrm{g}$ planta $^{-1}$ obtidas pelos frutos e flores, nessa época, variaram de 2.289,92 a 3.669,28 e na parte aérea $(6.600,94$ a $8.683,63)$, sendo os valores superiores aos obtidos por Canato et al. (2001) que foram de 1.490 e $2.840 \mu$ g planta $^{-1}$, respectivamente.

Aos 97DAT, para os tratamentos T50, T150 e T600, a menor extração acumulou no caule e ramos e foi maior nos frutos e flores. $O$ tratamento T300 teve a maior extração de zinco acumulada nas folhas e foi também menor no caule e ramos. Essa maior extração pelas folhas encontrada no tratamento T300 difere do resultado obtido por Belfort (1985) em que na colheita, a maior extração acumulou nos frutos e flores, e a extração pela parte aérea $(41.908 \mu \mathrm{g}$ planta $\left.^{-1}\right)$ foi superior aos obtidos neste experimento $(10.636,62$ a $11.211,41 \mu \mathrm{g}$ planta $\left.^{-1}\right)$. 

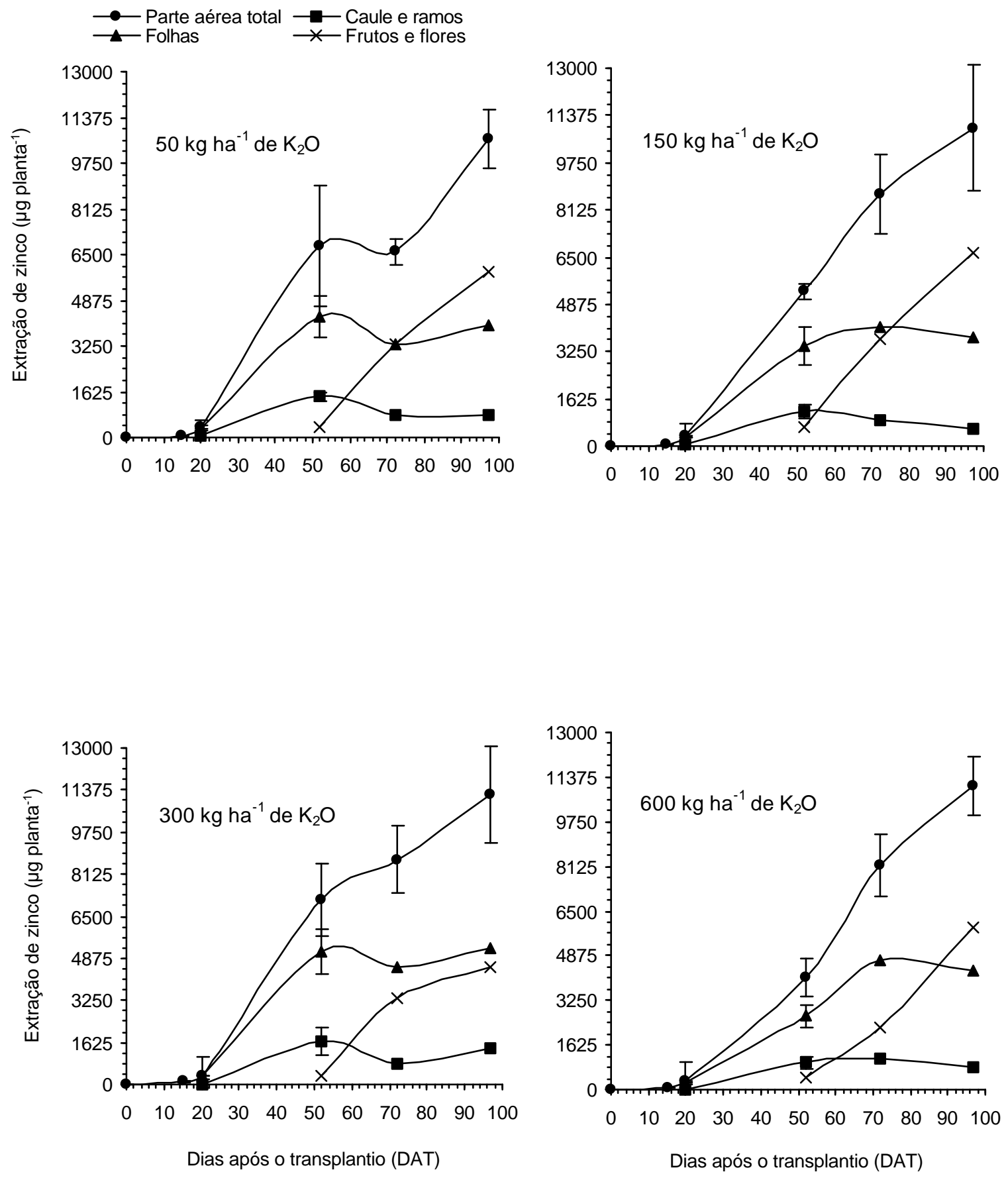

Figura 14 - Extração de zinco acumulado nos órgãos do meloeiro ao longo do ciclo nas doses de potássio. As linhas verticais indicam o erro padrão da média. 


\subsection{Extração de nutrientes no sistema convencional com adição de $\mathrm{CO}_{2}$ à água de irrigação}

\subsubsection{Nitrogênio}

Na Figura 15 pode-se observar que para as folhas, a tendência da extração de nitrogênio nos tratamentos T50 e T150 foi semelhante pois, aumentou até os 72DAT e depois diminuiu aos 97DAT. Para os tratamentos T300 e T600, a extração aumentou até os 52DAT e se manteve até os 97DAT.

No caule e ramos, todos os tratamentos apresentaram maior incremento da extração entre o 20 e 52DAT, e praticamente não se alterou até os 97DAT. Nos frutos e flores, a extração foi crescente até os 97DAT.

$\mathrm{Na}$ parte aérea verificou-se que o tratamento T150 foi o único em que a extração praticamente não se alterou após os 72DAT, pois os demais tratamentos tiveram um aumento da extração ao longo do ciclo. Percebe-se que a extração de nitrogênio acumulada na parte aérea foi mais influenciada pelo teor desse nutriente na massa de material seco dos frutos e flores.

Aos 52DAT, a maior extração acumulou nas folhas e foi menor nos frutos e flores em todos tratamentos. Aos 72DAT, para os tratamentos T50, T300 e T600, a menor extração acumulou no caule e ramos e foi semelhante nas folhas e frutos e flores. Para o tratamento T150, a extração foi maior nas folhas e menor no caule e ramos. Canato et al. (2001) obtiveram, nesse mesmo estádio fenológico, extrações de 1.350 e $2.040 \mathrm{mg} \mathrm{planta}^{-1}$ nos frutos e flores e na parte aérea respectivamente, resultados inferiores aos obtidos neste experimento.

Aos 97DAT, em todos tratamentos, a maior extração acumulou nos frutos e flores e foi menor no caule e ramos, resultados semelhantes aos obtidos por Belfort (1985) e Domingo Suárez (1991). Essa maior quantidade de nitrogênio acumulada nos frutos em todos tratamentos seguiu a mesma tendência encontrada por Rincón Sánchez et al. (1998). Nessa época, o valor maior de extração de nitrogênio acumulado na parte aérea ocorreu no tratamento T300 
(7078,50 $\mathrm{mg}$ planta $\left.^{-1}\right)$, sendo esse valor abaixo do obtido por Belfort (1985) que foi de $23.075,51 \mathrm{mg} \mathrm{planta}^{-1}$.
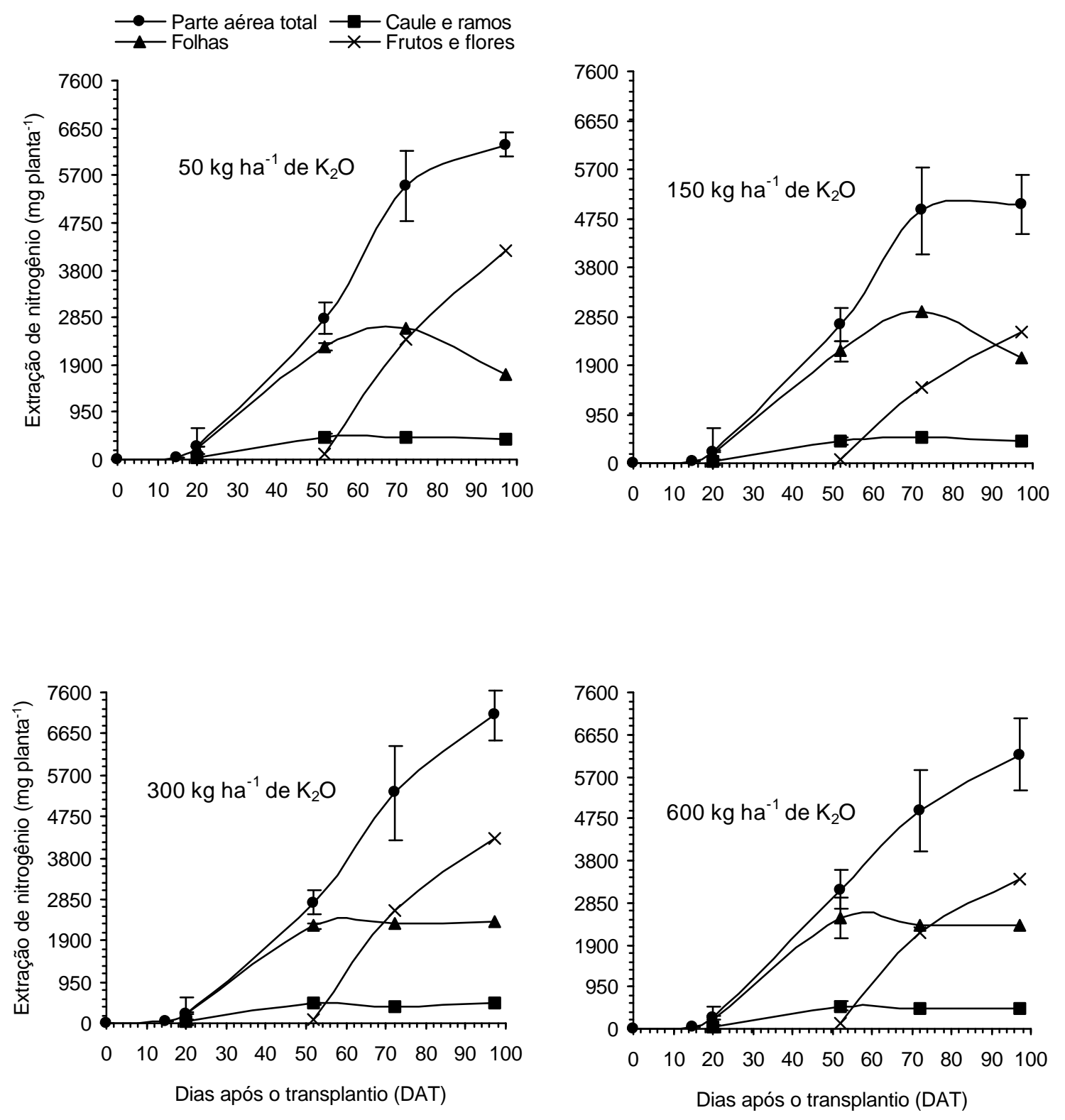

Figura 15 - Extração de nitrogênio acumulada nos órgãos do meloeiro cultivado com utilização da água carbonatada ao longo do ciclo nas doses de potássio. As linhas verticais indicam o erro padrão da média. 


\subsubsection{Fósforo}

Pela Figura 16 percebe-se que nos tratamentos T50 e T150, a extração de fósforo acumulou nas folhas teve a mesma tendência no caule e ramos, isto é, aumentou até os 52DAT e diminuiu com o tempo. Para os tratamentos T300 e T600, a extração acumulada nas folhas aumentou, principalmente, até os 52DAT, enquanto que no caule e ramos aumentou até os 52DAT e se manteve ao longo do ciclo. Nos frutos e flores, a extração aumentou até os 97DAT em todos tratamentos.

A tendência crescente da extração de fósforo acumulada na parte aérea ao longo das épocas avaliadas seguiu o que ocorreu nos frutos e flores. Provavelmente, foi mais influenciada pelo teor desse nutriente na massa de material seco dos frutos e flores.

Aos 52DAT, todos tratamentos tiveram a maior extração acumulada nas folhas e menor nos frutos e flores. Aos 72 e 97DAT, para os tratamentos T50, T300 e T600, a extração foi mais acumulada nos frutos e flores, seguindo as mesmas tendências encontradas por Belfort (1985) e Rincón Sánchez et al. (1998), e foi menor no caule e ramos. No tratamento T150, o que diferenciou foi que a extração acumulada nas folhas foi semelhante à dos frutos e flores aos 72DAT, e, aos 97DAT, teve a mesma tendência encontrada nos demais tratamentos.

Em todos os tratamentos, a extração de fósforo acumulada nos frutos e flores aos 72DAT foi menor que $500 \mathrm{mg}$ planta $^{-1}$ e coincide com o resultado obtido por Canato et al. (2001), que foi de $230 \mathrm{mg} \mathrm{planta}^{-1}$, no entanto, na parte aérea esses autores encontraram valores inferiores aos obtidos nesse experimento.

O maior valor de extração pela parte aérea obtida na colheita foi no tratamento T300 (931,45 mg planta $\left.{ }^{-1}\right)$, sendo esse valor abaixo do encontrado por Belfort (1985) (3.460,15 $\left.\mathrm{mg} \mathrm{planta}^{-1}\right)$. 

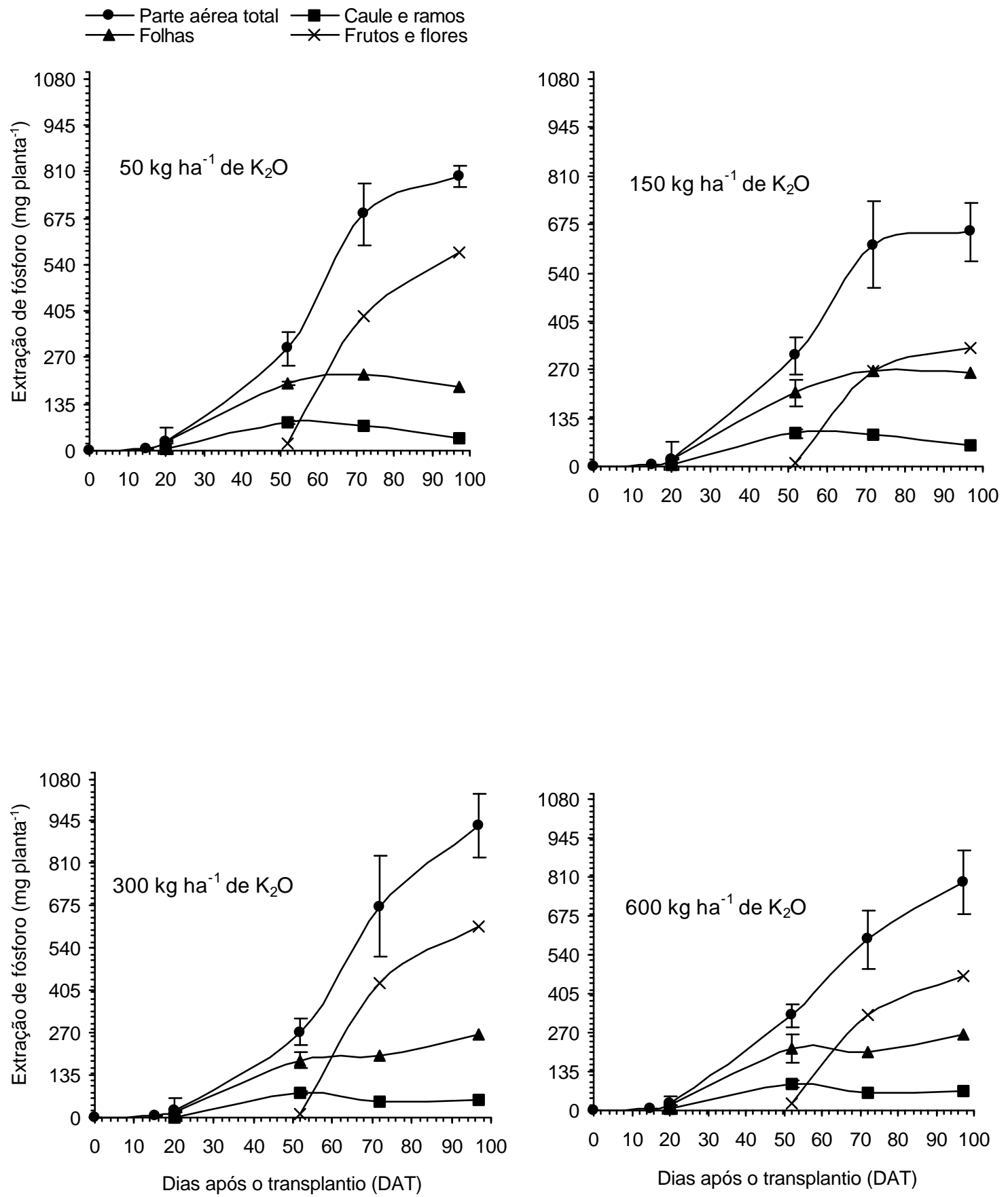

Figura 16 - Extração de fósforo acumulado nos órgãos do meloeiro cultivado com utilização da água carbonatada ao longo do ciclo nas doses de potássio. As linhas verticais indicam o erro padrão da média. 


\subsubsection{Potássio}

Em todos os tratamentos, a extração de potássio (Figura 17) acumulada nas folhas aumentou até os 52DAT, e teve uma leve redução ao longo das épocas avaliadas. Essa mesma tendência pôde ser observada no caule e ramos.

Nos frutos e flores, para os tratamentos T50 e T300, a extração aumentou até os 72DAT e depois diminuiu. Já para o T150 e T600, também aumentou até os 72DAT e praticamente não se alterou aos 97DAT. Na parte aérea, a extração aumentou até os 72DAT e depois diminuiu aos 97DAT, em todos tratamentos.

Aos 52DAT, a maior extração acumulou nas folhas e foi menor nos frutos e flores em todos tratamentos. Aos 72 e 97DAT, no tratamento T50, a extração foi maior nos frutos e flores e menor no caule e ramos, seguindo a mesma tendência encontrada por Belfort (1985) e Rincón Sánchez et al. (1998). Para os tratamentos T300 e T600, a menor extração acumulou no caule e ramos e foi semelhante às folhas e aos frutos e flores. No tratamento T150, a extração acumulada nas folhas foi maior nessas duas épocas, no entanto, aos 72DAT a extração pelos frutos e flores, pelo caule e ramos foram semelhantes, e aos 97DAT a acumulação no caule e ramos foi menor.

As extrações de potássio acumulada na parte aérea aos 72DAT foram de 5.510 a $6.990 \mathrm{mg} \mathrm{planta}^{-1}$, sendo superiores ao obtido por Canato et al. (2001) que foi de $4.710 \mathrm{mg}$ planta $^{-1}$.

$\mathrm{Na}$ colheita, o valor maior da extração acumulada na parte aérea foi no tratamento T600 $\left(6.533,60 \mathrm{mg}\right.$ planta $\left.^{-1}\right)$ que foi próximo ao valor obtido no tratamento T300 $\left(6.253,15 \mathrm{mg}_{\text {planta }}{ }^{-1}\right)$. No entanto, esses valores estão bem abaixo do encontrado por Belfort (1985) ressa mesma época $(28.904,77 \mathrm{mg}$ planta $^{-1}$ ). 

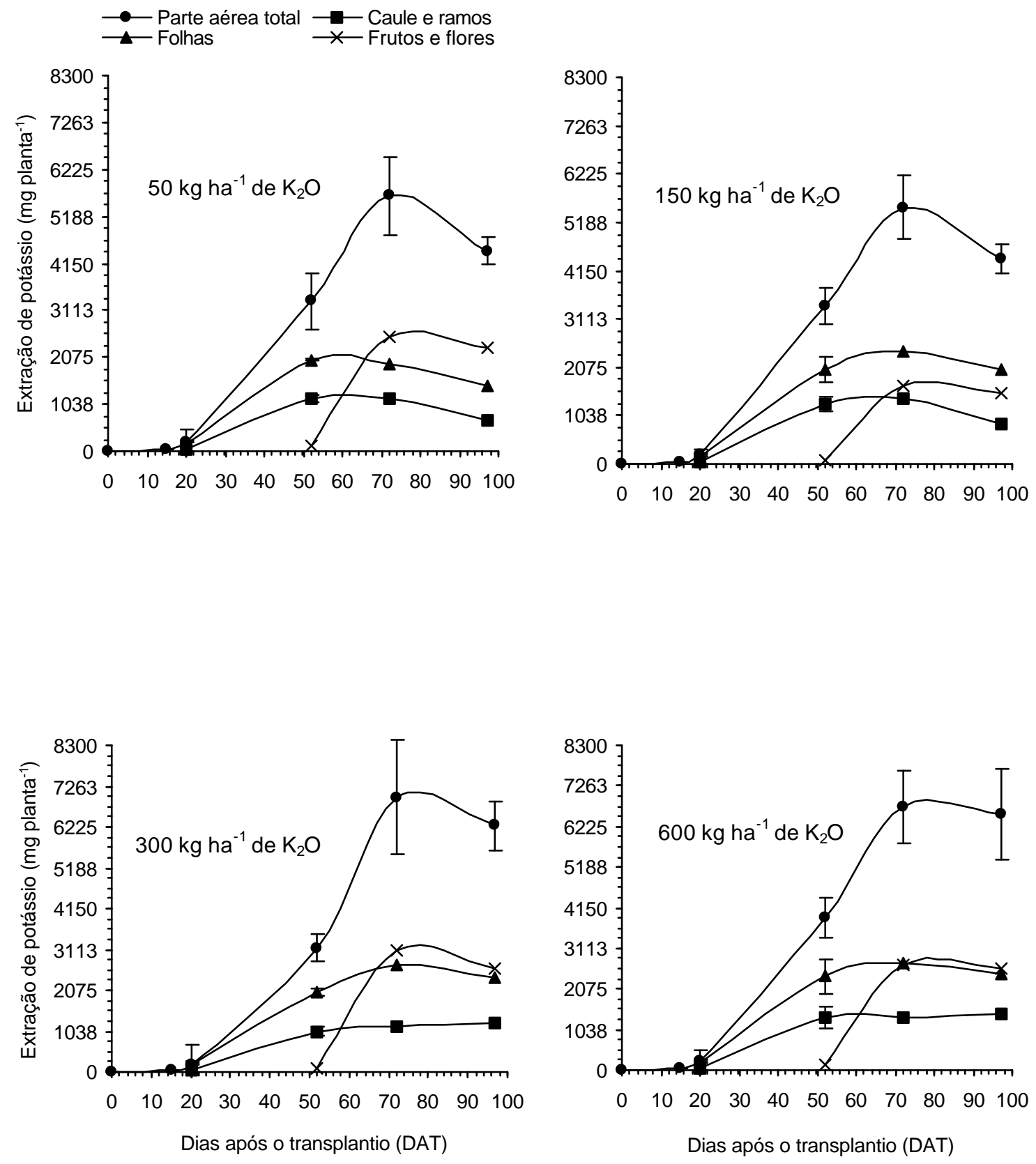

Figura 17 - Extração de potássio acumulada nos órgãos do meloeiro cultivado com utilização da água carbonatada ao longo do ciclo nas doses de potássio. As linhas verticais indicam o erro padrão da média. 


\subsubsection{Cálcio}

Pode-se observar na Figura 18 que nas folhas, para os tratamentos T150, T300 e T600, a extração de cálcio foi sempre crescente ao longo do ciclo. Para o tratamento T50, a extração nesse órgão aumentou até os 72DAT e praticamente se manteve aos 97DAT.

Em todos tratamentos, a extração de cálcio acumulada no caule e ramos foi levemente crescente até os 97DAT, e nos frutos e flores foi maior até os 72DAT, estando de acordo com Bernadac et al. (1996), que verificaram que $80 \%$ do cálcio foi acumulado durante a primeira metade do desenvolvimento do fruto.

$\mathrm{Na}$ parte aérea, todos os tratamentos tiveram valores maiores de extração do que o obtido por Canato et al. (2001) que foi de $3720 \mathrm{mg} \mathrm{planta}^{-1}$. Para todos tratamentos, pelo fato da extração de cálcio, nesse caso, apresentar a mesma tendência do que ocorreu nas folhas, percebe-se que a extração de cálcio pelo meloeiro provavelmente foi mais influenciada pelo teor de cálcio na massa de material seco das folhas.

Aos 52, 72 e 97DAT, a extração de cálcio acumulada em todos os órgãos estudados teve a mesma tendência. Aos 52 e aos 97DAT, a maior extração desse nutriente acumulou nitidamente nas folhas e foi menor nos frutos e flores, seguindo a mesma tendência encontrada por Belfort (1985). Pôde-se perceber aos 72DAT, que novamente a maior extração acumulou nas folhas, sendo a extração acumulada no caule e ramos semelhante à dos frutos e flores.

A maior presença do cálcio nas folhas coincide com os resultados de Rincón Sánchez et al. (1998), e sua menor ocorrência nos frutos e flores durante todo o ciclo, provavelmente esteja relacionado à baixa mobilidade desse nutriente na planta.

$\mathrm{Na}$ colheita, os tratamentos T150, T300 e T600 tiveram valores próximos da extração acumulada na parte aérea $(5.854,64 ; 5.226,67$ e $5.661,24 \mathrm{mg}$ 
planta $^{-1}$ respectivamente), estando bem abaixo do resultado obtido por Belfort (1985) $\left(12.742,04\right.$ mg planta $\left.^{-1}\right)$.
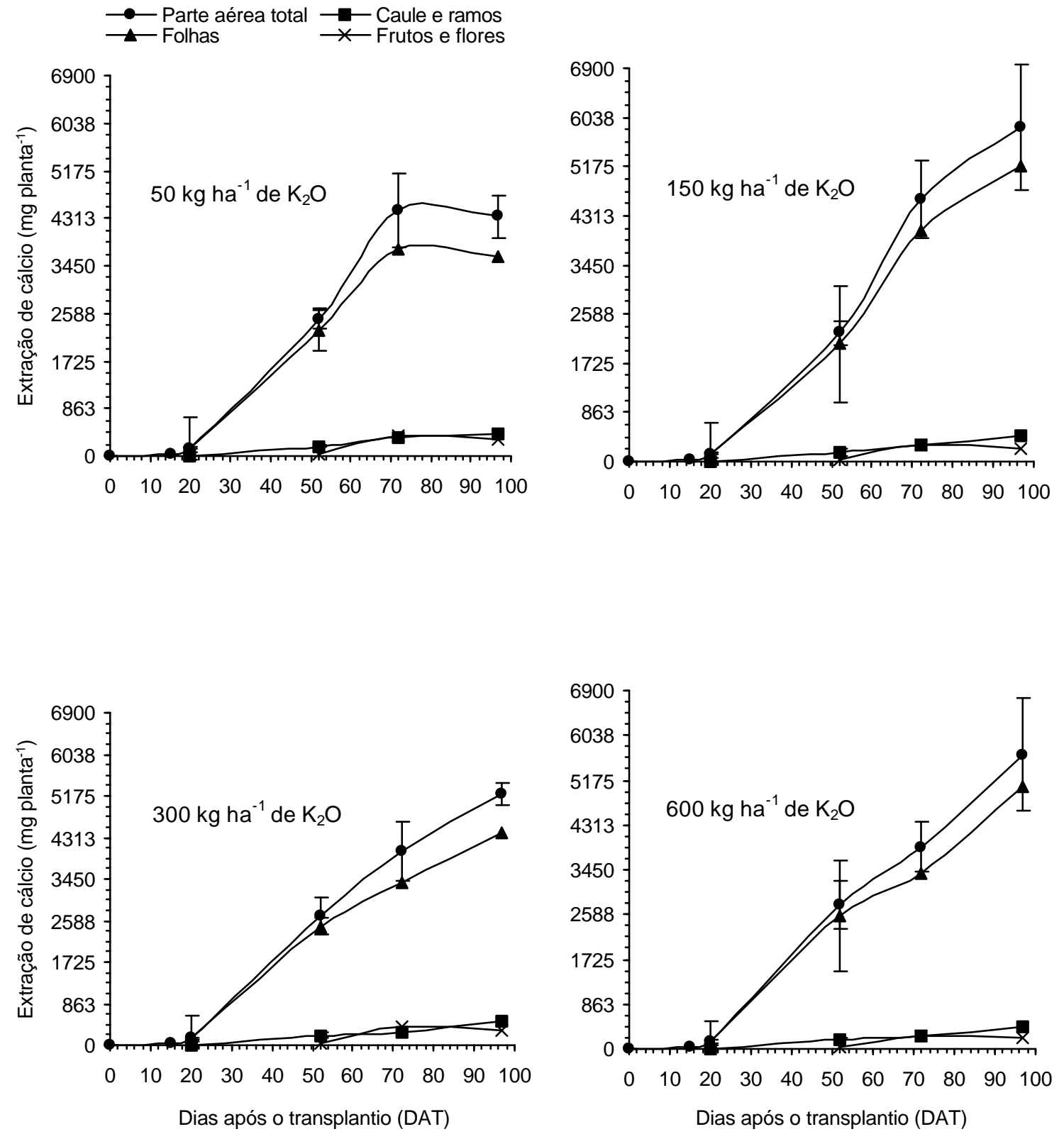

Figura 18 - Extração de cálcio acumulada nos órgãos do meloeiro cultivado com utilização da água carbonatada ao longo do ciclo nas doses de potássio. As linhas verticais indicam o erro padrão da média. 


\subsubsection{Magnésio}

A Figura 19 ilustra a extração de magnésio. Nas folhas, a extração foi crescente ao longo das épocas estudadas, em todos tratamentos. A tendência constante da extração desse nutriente a partir dos 52DAT até os 97DAT, pelo caule e ramos foi praticamente igual em todos tratamentos. Nos frutos e flores, a extração também aumentou ao longo do ciclo, para todos tratamentos, sendo os maiores valores encontrados nos tratamentos T50 e T300.

Observou-se que os valores da extração acumulada nas folhas, em todas épocas, foram superiores aos dos demais órgãos estudados, coincidindo com os resultados de Rincón Sánchez et al. (1998). Com isso, percebe-se que a extração desse nutriente acumulada na parte aérea provavelmente teve grande influência do teor de magnésio na massa de material seco das folhas.

Aos 52DAT, em todos tratamentos, caule e ramos acumularam maior extração do que os frutos e as flores. Aos 72 e 97DAT, a extração pelos frutos e flores foi superior à do caule e ramos, sendo que aos 72DAT, os valores de extração pelos frutos e flores desse nutriente não excederam $400 \mathrm{mg} \mathrm{planta}^{-1}$, semelhante ao resultado obtido por Canato et al. (2001).

Os valores de extração de magnésio obtidos por Belfort (1985) durante a frutificação foram superiores aos encontrados neste experimento. Na colheita, as extrações acumuladas na parte aérea foram de $1.580,20$ a $1.779,71 \mathrm{mg}$ planta $^{-1}$, sendo bem inferiores ao obtido por aquele autor que foi de 5.548,82 $\mathrm{mg} \mathrm{planta}^{-1}$. Entretanto, a extração pela parte aérea aos 72DAT obtida neste experimento (1.260 a $1.450 \mathrm{mg} \mathrm{planta}^{-1}$ ) foi maior do que a obtida por Canato et al. (2001) nesse mesmo estádio fenológico, que foi de $670 \mathrm{mg} \mathrm{planta}^{-1}$. 

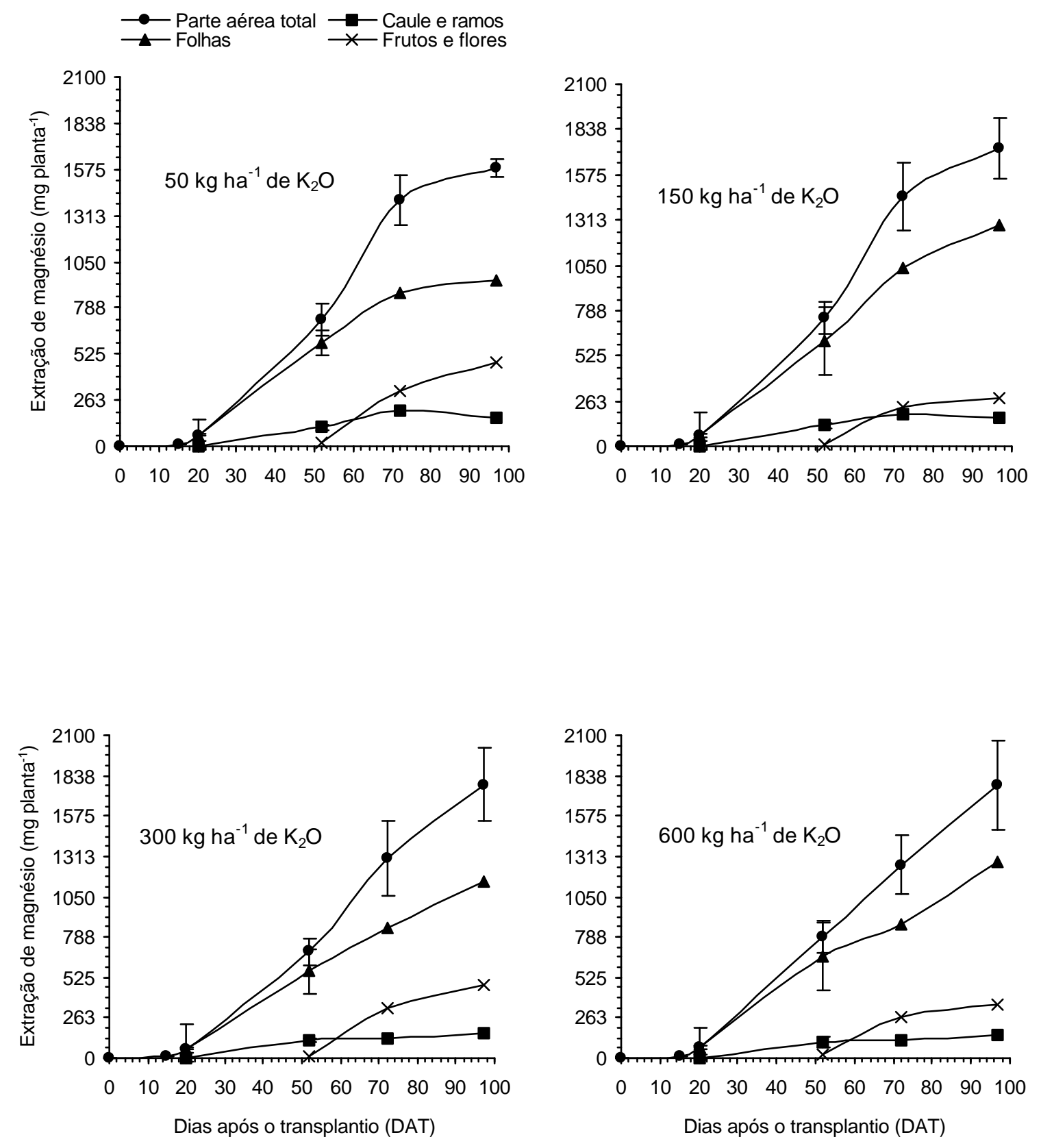

Figura 19 - Extração de magnésio acumulada nos órgãos do meloeiro cultivado com utilização da água carbonatada ao longo do ciclo nas doses de potássio. As linhas verticais indicam o erro padrão da média. 


\subsubsection{Enxofre}

Conforme a Figura 20, observa-se que a extração de enxofre acumulada nas folhas foi crescente ao longo das épocas avaliadas para os tratamentos T150, T300 e T600. No tratamento T50, essa extração aumentou até os 72DAT e praticamente não se alterou aos 97DAT.

Em todos os tratamentos, observou-se que a extração de enxofre acumulada no caule e ramos aumentou em menor intensidade durante todo 0 ciclo. Os frutos e flores, e a parte aérea tiveram sempre uma tendência crescente de extração acumulada. Provavelmente, o teor de enxofre na massa de material seco das folhas foi o que influenciou mais na extração acumulada na parte aérea.

Aos 52, 72 e 97DAT, todos tratamentos tiveram maior extração acumulada nas folhas, sendo que aos 52DAT, a menor extração acumulou nos frutos e flores. Aos 72 e 97DAT, para os tratamentos T50, T300 e T600, a menor extração foi acumulada no caule e ramos, enquanto que para o tratamento T150, a extração acumulada no caule e ramos foi semelhante à acumulada nos frutos e flores.

Os valores de extração acumulada nos frutos e flores aos 72DAT não excederam $240 \mathrm{mg} \mathrm{planta}^{-1}$, estando próximo ao valor obtido por Canato et al. (2001) que foi de $100 \mathrm{mg} \mathrm{planta}^{-1}$. Porém, a extração acumulada na parte aérea obtida por esses autores (160 $\mathrm{mg} \mathrm{planta}^{-1}$ ), nesse mesmo estádio fenológico, foi bem inferior aos valores encontrados neste experimento $(937,54$ a 1.080,54 mg planta $\left.^{-1}\right)$.

Aos 97DAT, na parte aérea, os valores de extração acumulados foram de $1.263,22$ a 1.485,39 $\mathrm{mg}_{\text {planta }}{ }^{-1}$, sendo próximos ao resultado obtido por Belfort (1985) que foi de $1.587,17 \mathrm{mg}_{\text {planta }}{ }^{-1}$. 

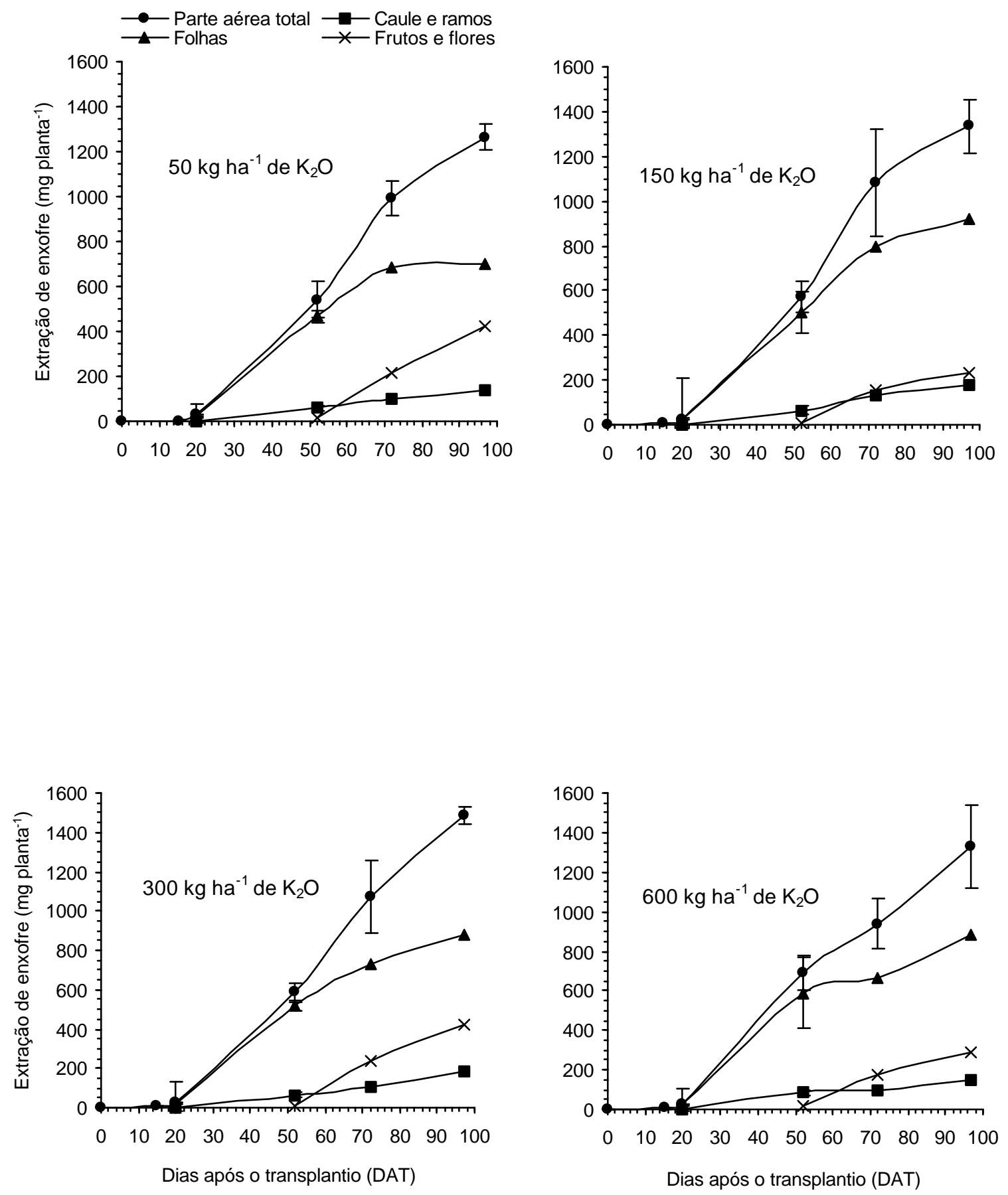

Figura 20 - Extração de enxofre acumulado nos órgãos do meloeiro cultivado com utilização da água carbonatada ao longo do ciclo nas doses de potássio. As linhas verticais indicam o erro padrão da média. 


\subsubsection{Boro}

Observa-se na Figura 21 que nas folhas, a extração de boro acumulada no tratamento T50 aumentou até os 72DAT e depois se manteve. Para o tratamento T150, a extração foi crescente em todas as épocas avaliadas. Nos tratamentos T300 e T600, as maiores extrações ocorreram aos 52 e 97DAT.

No caule e ramos, em todos tratamentos, a extração foi maior aos 52DAT e reduziu-se com o tempo. Nos frutos e flores, no T50, T300 e T600, a extração aumentou até aos 97DAT. Para o tratamento T150 ocorreu aumento até os 72DAT e praticamente não se alterou nos 97DAT. Na parte aérea, todos tratamentos tiveram extração crescente de boro ao longo do ciclo.

Aos 52DAT, em todos tratamentos, a extração maior acumulou nas folhas e a menor nos frutos e flores. Aos 72DAT, nos tratamentos T50, T300 e T600, a maior extração acumulou nos frutos e flores, e foi menor no caule e ramos. No tratamento T150, a diferença foi que a maior extração acumulou nas folhas.

Aos 97DAT, nos tratamentos T50 e T300, a extração acumulou mais nos frutos e flores, no tratamento T150 foi maior nas folhas, e para o tratamento T600 as folhas e os frutos e flores extraíram quantidades semelhantes de boro. Em todos tratamentos, nessa época, a menor extração acumulou no caule e ramos, seguindo a mesma grandeza obtida por Belfort (1985). Os valores de extração acumulados na parte aérea nessa época variaram de 5.170,67 a $6.815,99 \mu$ planta $^{-1}$ (T300), sendo esses valores menores que o obtido por Belfort (1985) que foi de $33.833 \mu$ planta $^{-1}$. 

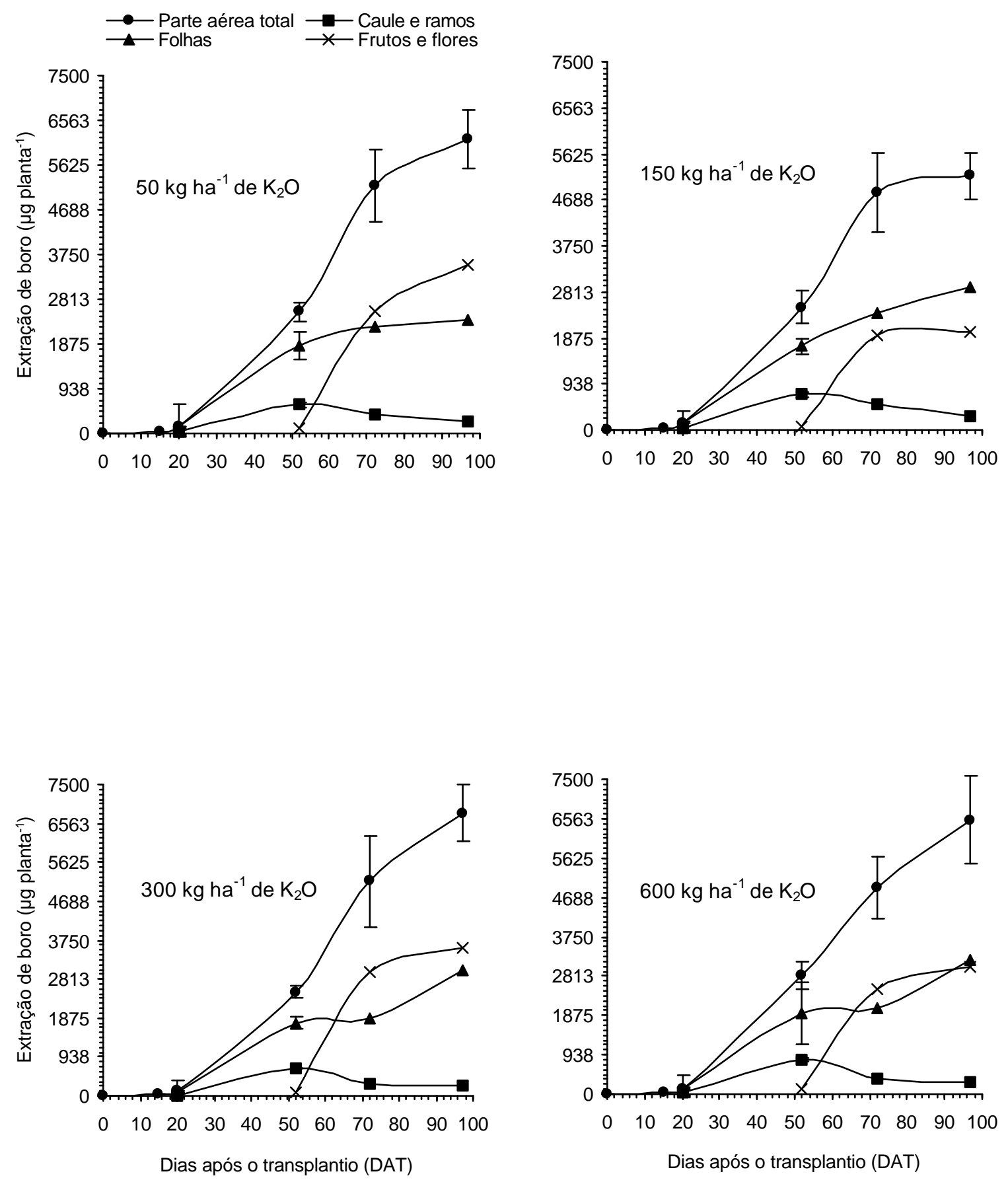

Figura 21 - Extração de boro acumulada nos órgãos do meloeiro cultivado com utilização da água carbonatada ao longo do ciclo nas doses de potássio. As linhas verticais indicam o erro padrão da média. 


\subsubsection{Cobre}

Pela Figura 22 observa-se que nas folhas, para os tratamentos T50 e T600, a extração de cobre aumentou até os 97DAT. Nos tratamentos T150 e T300 ocorreram aumentos até os 72DAT e praticamente se manteve aos 97DAT. Em todos tratamentos, a extração acumulada no caule e ramos e nos frutos e flores foram crescentes ao longo do ciclo.

$\mathrm{Na}$ parte aérea, a extração aumentou com o tempo em todos tratamentos. Para os tratamentos T150 e T300, a extração nesse caso seguiu a mesma tendência no caule e ramos, podendo provavelmente inferir-se que o teor de cobre na massa de material seco do caule e dos ramos seja o que mais influenciou na extração acumulada na parte aérea. No entanto, torna-se difícil explicar esse resultado, pois alguns produtos químicos utilizados no controle fitossanitário do meloeiro possuíam cobre.

Aos 52DAT, em todos tratamentos, a maior extração acumulou nas folhas e foi menor nos frutos e flores. Aos 72DAT, a extração foi maior no caule e ramos e menor nos frutos e flores. Nesse estádio fenológico, as extrações acumuladas pelos frutos e flores variaram de 700 a $1.200 \mu$ planta $^{-1}$, sendo os valores próximos ao obtido por Canato et al. (2001) que foi de $650 \mu \mathrm{g} \mathrm{planta}^{-1}$. No entanto, os valores de extração pela parte aérea, obtida nessa mesma época, $\left(4.986,74\right.$ a $\left.5.355,83 \mu \mathrm{g}_{\text {planta }}{ }^{-1}\right)$ foram maiores do que o encontrado por aqueles autores $\left(1.040 \mu\right.$ g planta $\left.^{-1}\right)$.

Aos 97DAT, para os tratamentos T150 e T600, a extração foi maior no caule e ramos e menor nos frutos e flores. Enquanto que para o tratamento T50 o que diferenciou foi que a extração acumulada nas folhas foi semelhante à do caule e ramos. No tratamento T300, caule e ramos acumularam maior extração, sendo a dos frutos e flores semelhante à das folhas. Esses resultados diferem do obtido por Belfort (1985) em que, nessa época, a maior extração de cobre acumulou nas folhas e 0 valor da extração pela parte aérea obtida por esse 
autor foi bem maior $\left(172.390 \mu\right.$ planta $\left.^{-1}\right)$ do que os obtidos neste experimento que foram de 6.160,46 a 8.129,61 $\mu \mathrm{g} \mathrm{planta}^{-1}$ (T600).
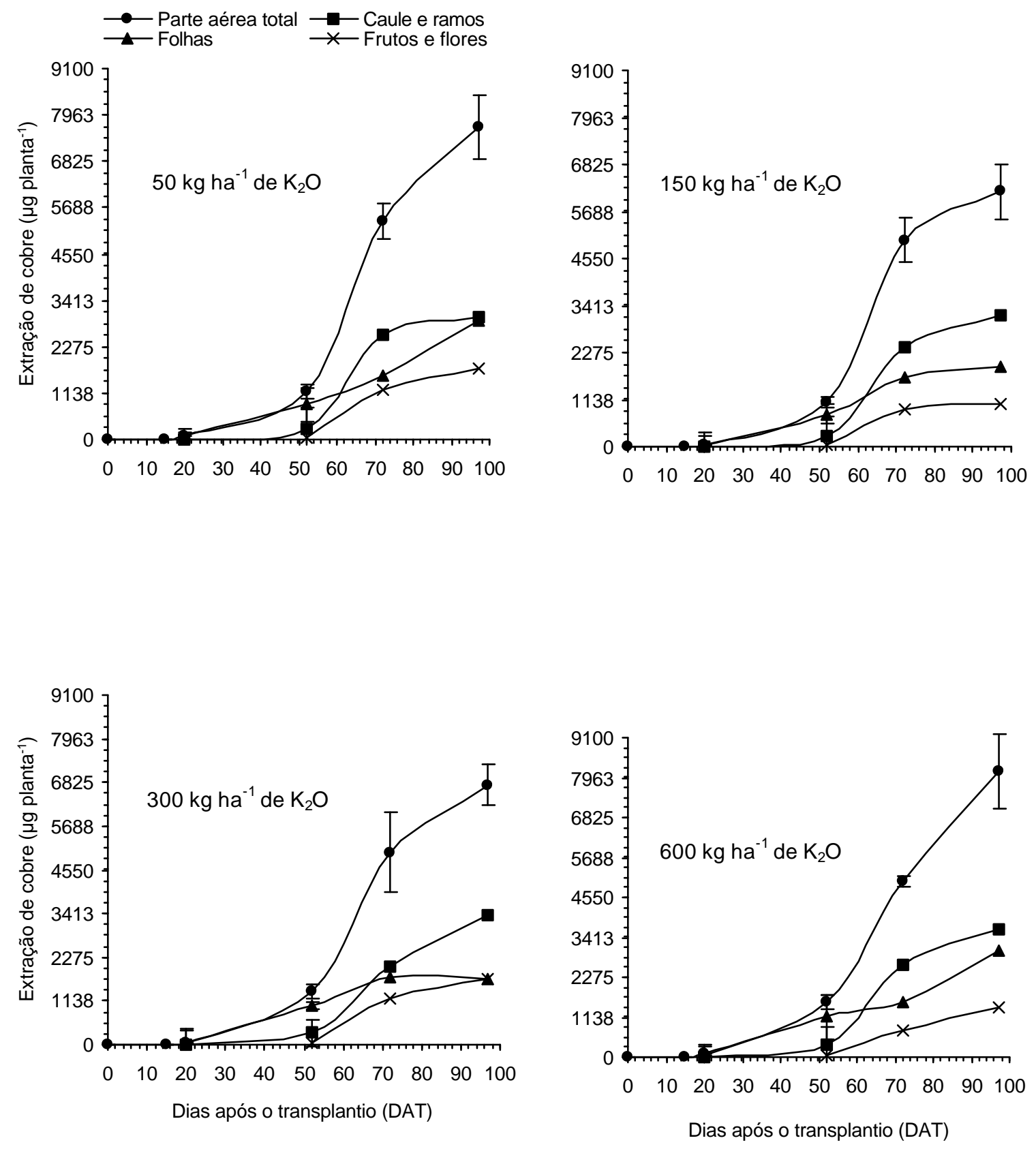

Figura 22 - Extração de cobre acumulada nos órgãos do meloeiro cultivado com utilização da água carbonatada ao longo do ciclo nas doses de potássio. As linhas verticais indicam o erro padrão da média. 


\subsubsection{Ferro}

Em relação às extrações de ferro (Figura 23) pode-se observar que todos os órgãos estudados apresentaram a mesma tendência de extração em todos tratamentos, pois, nas folhas, na parte aérea e nas flores e frutos, a extração foi crescente ao longo das épocas avaliadas. Para o caule e ramos, a extração aumentou até os 52DAT e praticamente não se alterou até os 97DAT.

Observa-se que a extração pela parte aérea, em todos tratamentos foi provavelmente mais influenciada pelo teor de ferro contido na massa de material seco das folhas.

Aos 52DAT, em todos tratamentos, a maior extração de ferro acumulou nas folhas e foi menor nos frutos e flores. Aos 72 e 97DAT, a maior extração continuou sendo a das folhas, enquanto caule e ramos tiveram a menor extração. Aos 72 DAT, os valores de extração de ferro acumulado nos frutos e flores do tratamento T50 $\left(9.059,89 \mu \mathrm{g}_{\text {planta }}{ }^{-1}\right)$ e do tratamento T300 $(8.079,09$ $\mu \mathrm{g}$ planta $^{-1}$ ) foram maiores do que o obtido por Canato et al. (2001), nesse mesmo estádio fenológico $\left(5.670 \mu \mathrm{g}_{\text {planta }}{ }^{-1}\right)$. Aos 97DAT, as extrações de ferro obtidas na parte aérea foram de 53.921,37 a 68.149,58 $\mathrm{gg} \mathrm{planta}^{-1}$ (T600) sendo esses valores menores do que o obtido por Belfort (1985) (169.062 $\mu \mathrm{g}$ planta $^{-1}$ ), nessa mesma época. 

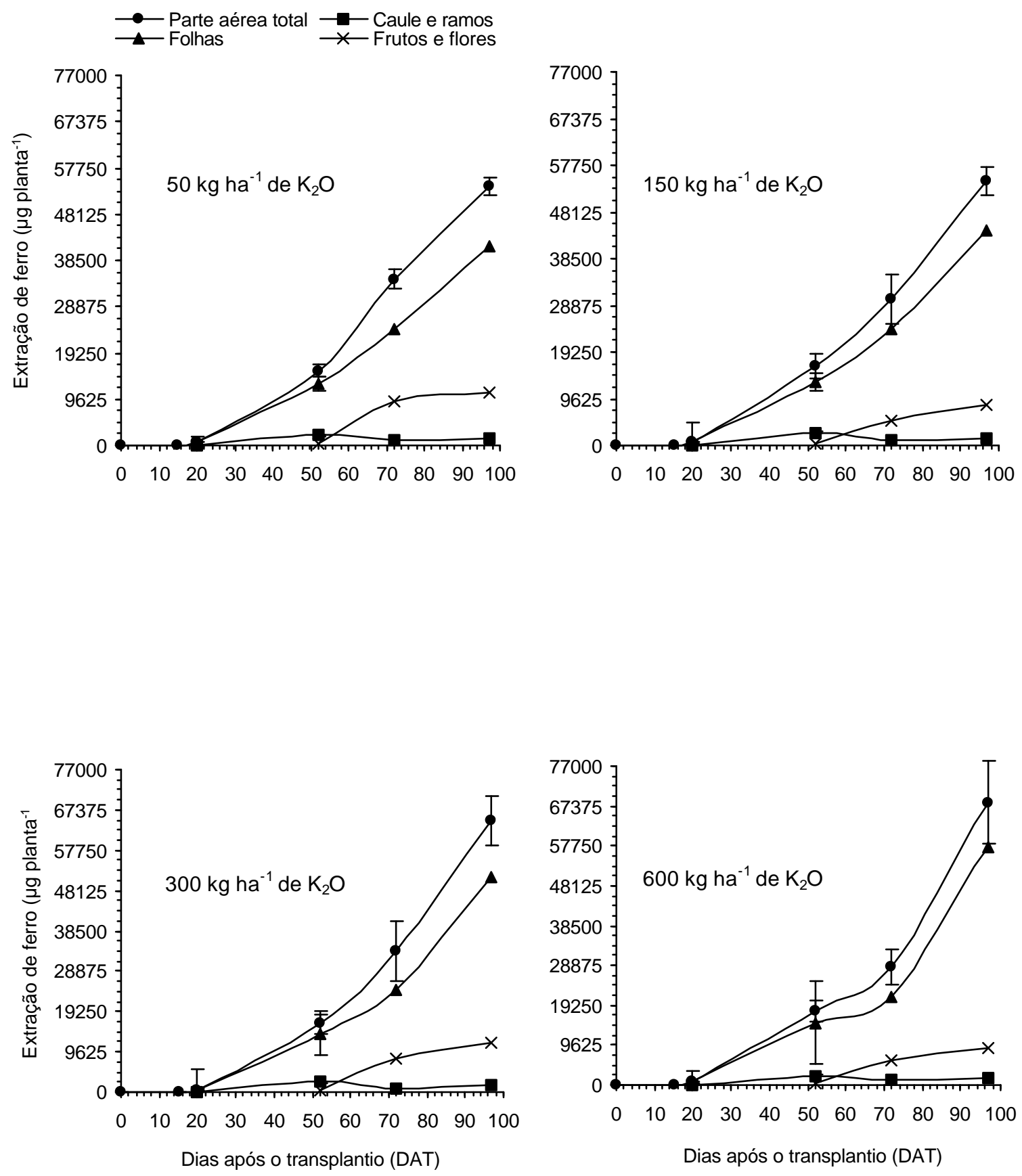

Figura 23 - Extração de ferro acumulada nos órgãos do meloeiro cultivado com utilização da água carbonatada ao longo do ciclo nas doses de potássio. As linhas verticais indicam o erro padrão da média. 


\subsubsection{Manganês}

Pela Figura 24 observa-se que em todos tratamentos, a extração de manganês acumulada nas folhas foi sempre crescente ao longo das épocas avaliadas. No caule e ramos, aumentou principalmente até os 52DAT. Nos frutos e flores, o maior incremento na extração ocorreu até os 72DAT e praticamente não se alterou até os 97DAT.

Em todos tratamentos, a extração de manganês acumulada na parte aérea seguiu a mesma tendência da extração acumulada nas folhas, que, provavelmente, sofreu maior influência do teor de manganês na massa de material seco das folhas.

Aos 52, 72 e 97DAT, em todos tratamentos, a extração foi maior nas folhas. Aos 52DAT foi menor nos frutos e flores e aos 72DAT no caule e ramos.

Os valores de extração aos 72DAT acumulados pelos frutos e flores variaram de 1.870 a $2.890 \mu$ g planta $^{-1}$ e os da parte aérea foram de $(19.197,66$

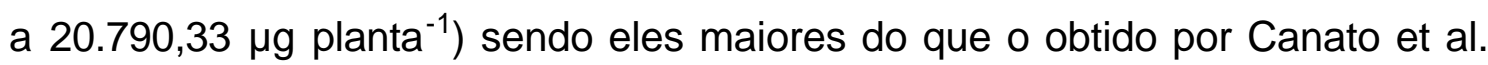
(2001), nesse mesmo estádio fenológico (890 e $4.200 \mu$ planta $^{-1}$ ), para os frutos e flores e para parte aérea respectivamente.

Aos 97DAT, nos tratamentos T50, T300 e T600, a extração foi menor no caule e ramos e para o tratamento T150, a extração acumulada pelos frutos e flores foi semelhante à do caule e ramos. Os valores de extração pela parte aérea nessa época foram de $25.777,78$ a $28.766,73 \mu$ planta $^{-1}$ (T600), sendo eles menores do que o obtido por Belfort (1985) que foi de $109.952 \mu$ glanta $^{-1}$. 

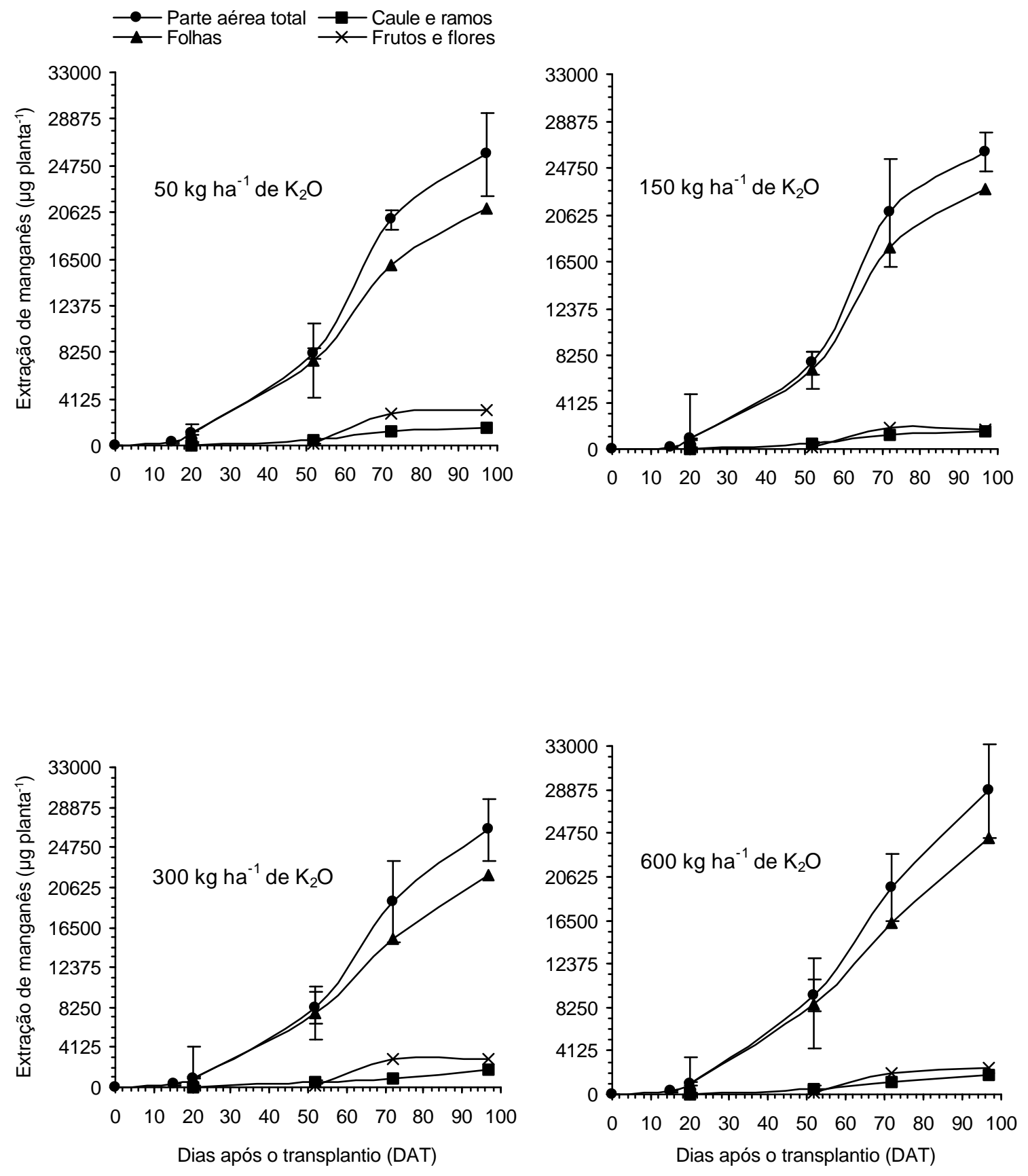

Figura 24 - Extração de manganês acumulada nos órgãos do meloeiro cultivado com utilização da água carbonatada ao longo do ciclo nas doses de potássio. As linhas verticais indicam o erro padrão da média. 


\subsubsection{Zinco}

Pode-se perceber pela Figura 25 que a extração de zinco acumulada nas folhas aumentou principalmente até os 72DAT, em todos tratamentos. No caule e ramos, para o T50, T300 e T600, a extração aumentou até os 52DAT e no T150 até os 72DAT.

A extração pelos frutos e flores aumentou até os 97DAT, em todos tratamentos, e provavelmente, o teor de zinco na massa de material seco desses órgãos bi o que mais influenciou a tendência crescente da extração pela parte aérea.

Aos 52DAT, todos os tratamentos tiveram maior extração acumulada nas folhas e menor nos frutos e flores. Aos 72DAT, para os tratamentos T150 e T600 observou-se uma maior extração acumulada nas folhas e para os tratamentos T50 e T300, a extração acumulada nas folhas foi semelhante à dos frutos e flores. Nessa época, para todos tratamentos, a extração menor foi acumulada no caule e ramos, e os valores de extração em $\mu \mathrm{g}$ planta $^{-1}$ acumulados nos frutos e flores variaram de 2.860 a 4.890 e na parte aérea foram de $9.398,29$ a 10.425,83 sendo maiores do que os valores obtidos por Canato et al. (2001) tanto para os frutos e flores $\left(1.490 \mu \mathrm{g}_{\text {planta }}{ }^{-1}\right)$ como para a parte aérea $\left(2.840 \mu \mathrm{g} \mathrm{planta}^{-1}\right)$.

Aos 97DAT, em todos tratamentos, a extração menor acumulou no caule e ramos. A maior extração acumulou nos frutos e flores nos tratamentos T50 e T300, e nas folhas no tratamento T150. No tratamento T600, a extração acumulada nas folhas foi semelhante à dos frutos e flores, e esse resultado é diferente do obtido por Belfort (1985) em que verificou-se maior extração de zinco acumulada nos frutos e flores. Os valores de extração de zinco acumulados na parte aérea obtida neste experimento foram de 11.119,18 a 12.617,66 $\mu$ planta $^{-1}$, estando bem abaixo do valor obtido por Belfort (1985) $\left(41.908 \mu\right.$ planta $\left.^{-1}\right)$. 

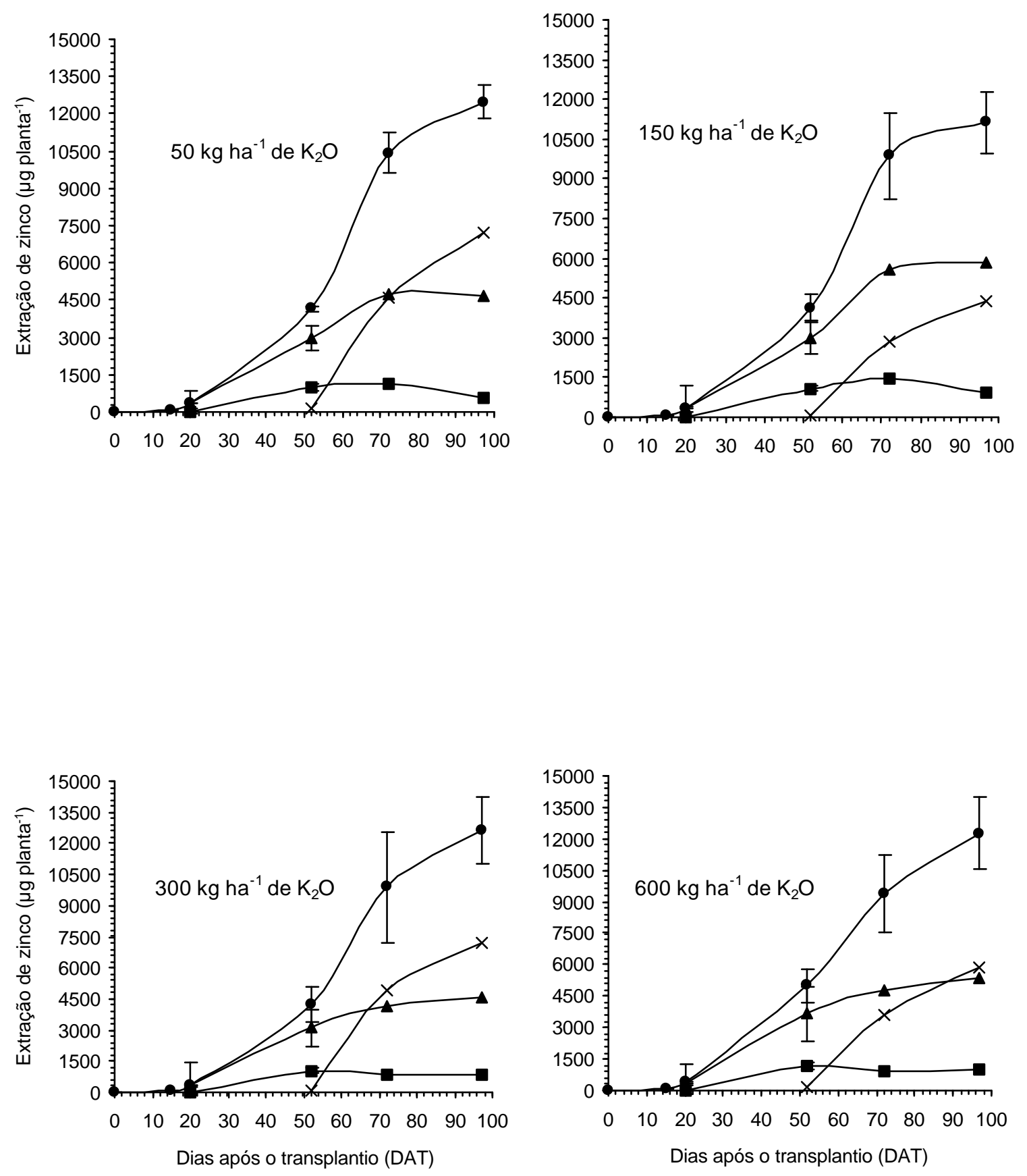

Figura 25 - Extração de zinco acumulada nos órgãos do meloeiro cultivado com utilização da água carbonatada ao longo do ciclo nas doses de potássio. As linhas verticais indicam o erro padrão da média. 


\subsection{Extração comparativa de nutrientes}

A ordem decrescente da extração de macronutrientes pela parte aérea do meloeiro rendilhado (Figura 26a e 26b), nos dois experimentos (sistema convencional e convencional com adição de $\mathrm{CO}_{2}$ ), foi a seguinte: potássio > nitrogênio > cálcio > magnésio > enxofre > fósforo e coincidem com os resultados de Rincón Sánchez et al. (1998) e de Belfort (1985). A extração menor de fósforo seguiu o mesmo resultado obtido por Tyler \& Lorenz (1964), no entanto, esses autores verificaram, durante todo o ciclo, que o nitrogênio foi o macronutriente mais extraído, seguido pelo potássio.

Aos 97DAT e apenas para o sistema com $\mathrm{CO}_{2}$, o nitrogênio passou a ser o macronutriente mais extraído (6.147,42 $\left.\mathrm{mg} \mathrm{planta}^{-1}\right)$, e a extração de potássio reduziu $\left(5.404,66 \mathrm{mg}_{\text {planta-1 }}{ }^{-1}\right)$, sendo semelhante à de cálcio $(5.271,71 \mathrm{mg}$ planta $^{-1}$ ) (Figura 26b). Deste modo, para o melão rendilhado, considerando a utilização de $\mathrm{CO}_{2}$, o potássio deva ser fornecido preferencialmente até próximo aos 72DAT. Os valores obtidos na extração de potássio aos 72DAT são semelhantes aos obtidos por Canato et al. (2001) nesse mesmo estádio fenológico.

A ordem decrescente da extração de micronutrientes (Figura 26c e 26d), nos dois sistemas utilizados foi a seguinte: ferro > manganês > zinco > cobre boro. Com exceção do boro, estes resultados seguem a mesma seqüência obtida por Canato et al. (2001). A maior extração de ferro e a menor de boro também são semelhantes aos de Belfort (1985). Neste caso, a extração de cobre foi menor que a extração de manganês e de zinco, enquanto que este autor obteve maior extração de cobre do que manganês e zinco.

Verificou-se em todos os tratamentos, que o incremento maior da extração dos nutrientes estudados pela parte aérea do meloeiro rendilhado ocorreu no período entre o início do florescimento e o início da frutificação, resultado semelhante ao obtido por Tyler \& Lorenz (1964) e por Silva et al. 
(2000) em que verificaram absorção mais rápida dos macronutrientes a partir do florescimento.
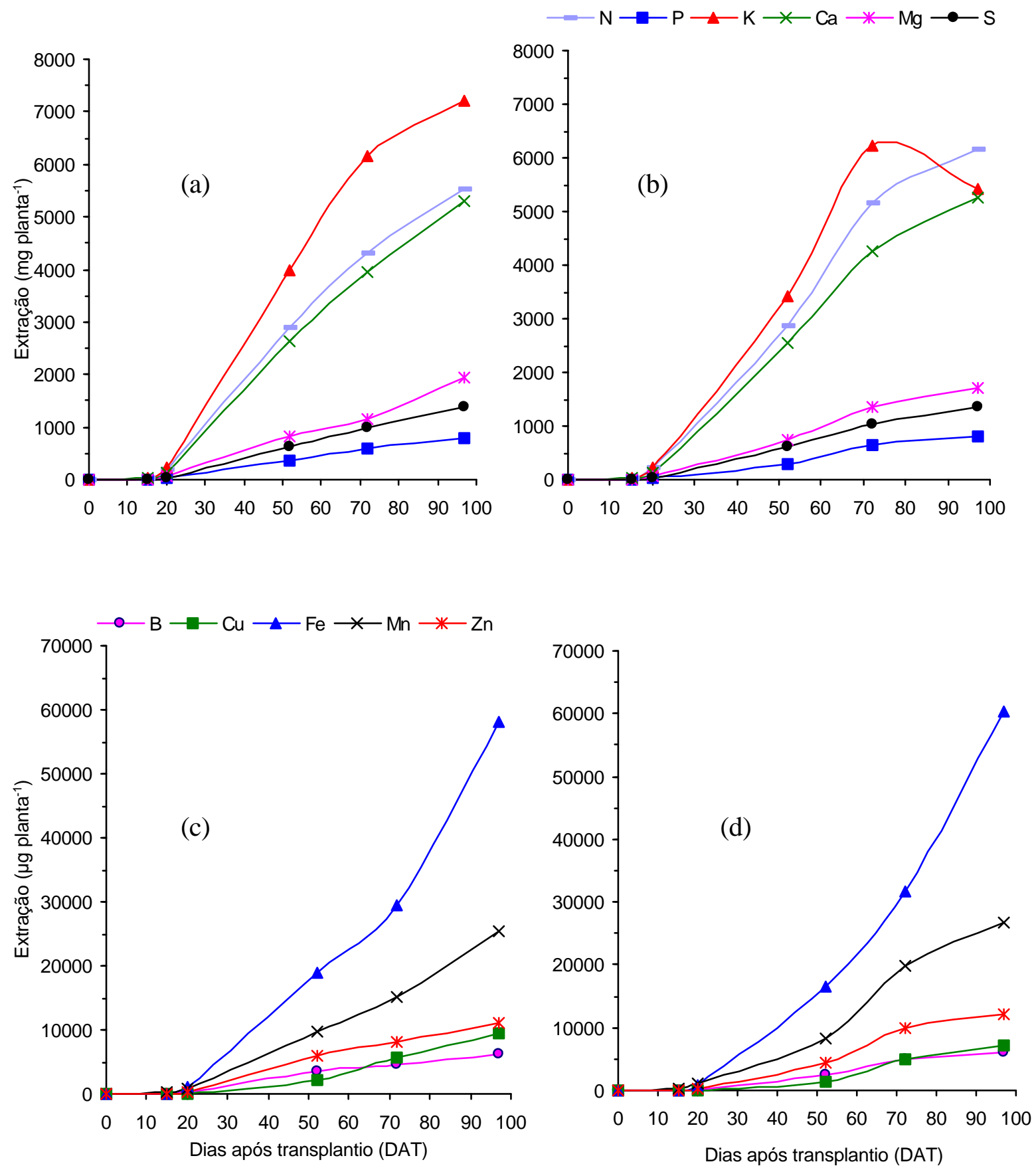

Figura 26 - Extração de nutrientes pela parte aérea do meloeiro rendilhado ao longo do ciclo obtida no sistema convencional (a e c) e no sistema com utilização de $\mathrm{CO}_{2}$ (b e d). Média de todos tratamentos. 
$\mathrm{Na}$ colheita, tanto a adição de $\mathrm{CO}_{2}$ como as doses de potássio não apresentaram efeitos significativos, na extração de nutrientes, com exceção de potássio, magnésio e zinco (Tabela 8). Pinto (1997) não obteve também diferenças nas concentrações de nutrientes nas folhas do meloeiro em relação à testemunha, com exceção para o boro onde o valor foi superior ao da testemunha. Storlie \& Heckman (1996b) também verificaram que não houve diferença na concentração de macronutrientes e micronutrientes, em plantas de pimentão cultivadas com a utilização de $\mathrm{CO}_{2}$ na água de irrigação.

Para o potássio, não houve interação significativa entre as doses de potássio e os sistemas de cultivo. No entanto, a utilização da água carbonatada promoveu diminuição $(\mathrm{P}<0,05)$, independente da dose de potássio, na extração desse nutriente pela parte aérea na colheita (Tabela 8), resultado diferente do obtido por Novero et al. (1991), Ibrahim (1992), Gomes (2001) e Araújo (2002), que obtiveram aumentos nas concentrações de potássio nas plantas que receberam $\mathrm{CO}_{2}$ aplicado na água de irrigação. Nos dois experimentos, a extração maior de potássio ocorreu na dose de $600 \mathrm{~kg} \mathrm{ha}^{-1}$ ajustado por um modelo linear ( $\left.y=4959,9398+4,8908 X ; R^{2}=0,40^{* *} ; C V=29,2 \%\right)$.

Para o magnésio, a concentração de $\mathrm{CO}_{2}$ utilizada na água de irrigação ocasionou uma diminuição $(\mathrm{P}<0,05)$ na extração, em relação ao cultivo convencional (Tabela 8), resultado esse, diferente do encontrado por Arteca et al. (1979) e por Ibrahim (1992) que verificaram aumentos da concentração desse nutriente em plantas de batata e de pepino, respectivamente, cultivadas com enriquecimento de $\mathrm{CO}_{2}$ na água de irrigação. Não houve efeito significativo de doses de potássio, bem como a interação não foi significativa.

Quanto ao zinco, ocorreu aumento $(P<0,05)$ na extração em relação ao cultivo convencional (Tabela 8), resultado semelhante ao obtido por Mauney \& Hendrix (1988), Novero et al. (1991), Ibrahim (1992), D' Andria et al. (1993) e por Stoffella et al. (1995), respectivamente em plantas de algodão, tomate, pepino, em frutos de tomateiro e em mudas de citros. Provavelmente, este aumento na absorção de zinco pelas plantas pode ser atribuído ao abaixamento 
do $\mathrm{pH}$ do solo ocasionado pela água carbonatada e o maior crescimento das raízes, ocasionado pelo $\mathrm{CO}_{2}$. Não houve efeito significativo de doses de potássio, bem como a interação não foi significativa.

Tabela 8. Média das extrações pela parte aérea do meloeiro em (mg planta ${ }^{-1}$ ) para os macronutrientes, e em $\mu \mathrm{g}$ planta ${ }^{-1}$ ) para os micronutrientes no sistema convencional e no sistema convencional com adição de $\mathrm{CO}_{2}$ na água de irrigação

\begin{tabular}{llc}
\hline Nutriente & \multicolumn{2}{c}{ Sistema de cultivo } \\
& Convencional & Convencional $+\mathrm{CO}_{2}$ \\
\hline Nitrogênio & $5.535,40 \mathrm{a}$ & $6.147,40 \mathrm{a}$ \\
Fósforo & $802,22 \mathrm{a}$ & $794,25 \mathrm{a}$ \\
Potássio & $7.205,20 \mathrm{a}$ & $5.404,70 \mathrm{~b}$ \\
Cálcio & $5.310,60 \mathrm{a}$ & $5.271,70 \mathrm{a}$ \\
Magnésio & $1.929,79 \mathrm{a}$ & $1.715,48 \mathrm{~b}$ \\
Enxofre & $1.369,13 \mathrm{a}$ & $1.352,44 \mathrm{a}$ \\
Boro & $6.272,00 \mathrm{a}$ & $6.172,40 \mathrm{a}$ \\
Cobre & $9.404,10 \mathrm{a}$ & $7.176,50 \mathrm{a}$ \\
Ferro & $58.082,00 \mathrm{a}$ & $60.313,00 \mathrm{a}$ \\
Manganês & $25.280,00 \mathrm{a}$ & $26.809,00 \mathrm{a}$ \\
Zinco & $10.955,70 \mathrm{~b}$ & $12.116,90 \mathrm{a}$ \\
\hline Médias seguidas pela mesma letra, na linha, não diferem entre si, pelo teste de Tukey a 5\% de \\
probabilidade.
\end{tabular}




\section{CONCLUSÕES}

Os resultados obtidos neste trabalho permitiram as seguintes conclusões:

- A extração de nutrientes acumulados na parte aérea do meloeiro rendilhado teve maior incremento entre o início do florescimento e o início da frutificação, independente do tratamento.

- A ordem de extração dos macronutrientes acumulados na parte aérea foi: potássio > nitrogênio > cálcio > magnésio > enxofre > fósforo. Com a utilização da água carbonatada, o nitrogênio passou a ser o macronutriente mais extraído, na colheita.

- A ordem da extração de micronutrientes acumulados na parte aérea foi: ferro $>$ manganês > zinco > cobre boro;

- A água carbonatada ocasionou diminuição da extração acumulada de potássio e magnésio e aumento da extração de zinco acumulados na parte aérea.

- As doses de potássio aumentaram a extração desse nutriente acumulado na parte aérea da planta, não influenciando os demais nutrientes na colheita.

- A dose de $300 \mathrm{~kg} \mathrm{ha}^{-1}$ de $\mathrm{K}_{2} \mathrm{O}$ proporcionou a maior produção de frutos, 0 maior peso médio e comprimento médio dos frutos comerciais. 
- A aplicação de $\mathrm{CO}_{2}$ na água de irrigação proporcionou aumento da ordem de $11 \%$ na produção total de frutos, $20 \%$ na produção comercial, e $23 \%$ no número de frutos comerciais. 


\section{REFERÊNCIAS BIBLIOGRÁFICAS}

ALARCÓN, A.L.; MADRID, R.; EGEA, C.; GUILLÉN, I. Calcium deficiency provoked by the application of different forms and concentrations of $\mathrm{Ca}^{2+}$ to soil-less cultivated muskmelons. Scientia Horticulturae, v.81, p.89-102, 1999.

ALVES, R. E. (Org.) Melão: Pós-colheita. Brasília: EMBRAPA, Comunicação para Transferência de Tecnologia, 2000. 43p. (Frutas do Brasil, 10).

ARAUJO, J.P. Cultura do melão. Petrolina: EMBRAPA, Centro de Pesquisa Agropecuária do Trópico Semi-Árido, 1980. 40p.

ARAÚJO, W.F. Aplicação de água carbonatada em abobrinha cultivada em solo com e sem cobertura plástica. Piracicaba, 2002. 86p. Tese (Doutorado) Escola Superior de Agricultura "Luiz de Queiroz", Universidade de São Paulo.

ARTECA, R. N.; POOVAIAH, B.W.; SMITH, O. E. Changes in carbon fixation, tuberization and growth induced by $\mathrm{CO}_{2}$ application to the root zone of potato plants. Science, n. 205, p. 1279-1280, 1979.

BAR-YOSEF, B. Advances in fertigation. Advances in Agronomy, v.65, p.1-77, 1999. 
BASILE, G.; ARIENZO, M.; ZENA, A. Soil nutrient mobility in response to irrigation with carbon dioxide enriched water. Communications in Soil Science and Plant Analysis, v. 11/12, n.24, p.1183-1195, 1993.

BELFORT, C.C. Acumulação de matéria seca e recrutamento de nutrientes em melão (Cucumis melo I. cv. Valenciano Amarelo CAC) cultivado em Latossolo Vermelho Amarelo em Presidente Wenceslau - S.P. Piracicaba, 1985. 72p. Tese (Doutorado) - Escola Superior de Agricultura "Luiz de Queiroz", Universidade de São Paulo.

BERNADAC, A.; JEAN-BAPTISTE, I.; BERTONI, G.; MORARD, P. Changes in calcium contents during melon (Cucumis melo L.) fruit development. Scientia Horticulturae, v.66, p.181-189, 1996.

BHAN, K.C.; HUFFAKER, R.C.; BEDRI, A.A.; MUELLER, R.T.; JEFFREYS, R.A.; CARMACK, R.M.; BIELY, M.I.; WALLACE, A. Possible relationships of bicarbonate or $\mathrm{CO}_{2}$ assimilation to cation accumulation by plant roots. Soil Science, v.80, n.5, p.276-284, 1960.

BLANCO, M.C.S.G.; GROPPO, G.A.; TESSARIOLLI NETO, J. Melão (Cucumis melo L.). In: GRAZIANO, J.R. (Coord.) Manual técnico das culturas. 2.ed. Campinas: Editora CATI, 1997. t.2, p.77-81.

BRANDÃO FILHO, J.V.T.; VASCONCELLOS, M.A.S. A cultura do meloeiro. In: GOTO, R.; TIVELLI, S.W. (Ed.). Produção de hortaliças em ambiente protegido: condições subtropicais. São Paulo: Fundação Editora da UNESP, 1998. p.161-193. 
BROWN, J.C. An evaluation of bicarbonate-induced iron chlorosis. Soil Science, v.80, n.5, p.246-247, 1960.

CANATO, G.H.D.; BARBOSA, J.C.; CECÍLIO FILHO, A.B. Acúmulo de macro e micronutrientes em melão rendilhado cultivado em casa de vegetação. In: CONGRESSO BRASILEIRO DE OLERICULTURA, 1.; ENCONTRO SOBRE PLANTAS MEDICINAIS, AROMÁTICAS E CONDIMENTARES 41., Brasília, 2001. Resumos. Brasília: Finep, 2001b. p. 256.

CANATO, G.H.D.; BARBOSA, J.C.; CECÍLIO FILHO, A.B. Concentração de macro e micronutrientes em melão rendilhado cultivado em casa de vegetação. In: CONGRESSO BRASILEIRO DE OLERICULTURA, 1.; ENCONTRO SOBRE PLANTAS MEDICINAIS, AROMÁTICAS E CONDIMENTARES 41., Brasília, 2001. Resumos. Brasília: Finep, 2001a. p. 256.

CARARO, D.C. Efeito de diferentes lâminas de água na presença e ausência de $\mathrm{CO}_{2}$ injetado na água de irrigação sobre a cultura do tomate (Lycopersicon esculentum Mill.) cultivado em estufa. Piracicaba, 2000. 70p. Dissertação (Mestrado) - Escola Superior de Agricultura "Luiz de Queiroz", Universidade de São Paulo.

CARNEIRO FILHO, J. Produção e qualidade de frutos de melão cantaloupe influenciadas pela poda e pelo tutoramento, em condições de estufa e de campo. Viçosa, 2001. 102p. Dissertação (M.S.) - Universidade Federal de Viçosa.

CARRIJO, O.A.; MAROUELLI, W.A.; SILVA, H.R. Manejo da água na produção de hortaliças em cultivo protegido. Informe Agropecuário, v. 20, n.200/201, p.45-51. 1999. 
CHAUDHURI, U.N.; KIRKHAM, M.B.; KANEMASU, E.T. Root growth of winter wheat under elevated carbon dioxide and drought. Crop Science, v.30, p.853-857, 1990.

CRAMER, M.D.; OBERHOLZER, J.A.; COMBRINK, N.J.J. The effect of supplementation of root zone dissolved inorganic carbon on fruit yield and quality of tomatoes (cv 'Daniella') grown with salinity. Scientia Horticulturae, v.89, p.269-289, 2001.

D`ANDRIA, R.; MAGLIULO, V.; MAGGIO, A.; BASILE, G.; ARIENZO, M. Soil and plant nutrient modifications in response to irrigation with $\mathrm{CO}_{2}$ enriched water on tomato. Acta Horticulturae, n.335, p.557-562, 1993.

DIAS, N. S.; MEDEIROS, J.F.de; SATHLER, N. S. Produção de melão sob duas densidades de plantio, em diferentes tipos e espaçamentos de gotejadores. Revista Brasileira de Engenharia Agrícola e Ambiental, v.4, n.3, p.321-326, 2000.

DOMINGO SUÁREZ, F. Demanda de nitrógeno y eficiência de la fertilización de melón reticulado (Cucumis melo L. var reticulatus Naud). Ciencia e Investigación Agraria, v.18, n.3, p.101-109, 1991.

DURÃO, P.L.; GALVÃO, A.C. Gás carbônico em irrigação. São Paulo. Ciência Hoje, v.19, n.110, 1995. Suplemento.

EMPRESA BRASILEIRA DE PESQUISA AGROPECUÁRIA. Sistema brasileiro de classificação de solos. Brasília, 1999. 412p. 
FARIA, C.M.B. de. Nutrição mineral e adubação do melão. Petrolina: EMBRAPA, CPATSA, 1990. 26p. (Circular Técnica, 22).

FARIA, C.M.B. de; FERREIRA, J.R.; POSSÍDIO, E.L. de. Adubação orgânica e mineral na cultura do melão num Vertissolo do Submédio São Francisco. Pesquisa Agropecuária Brasileira, v.29, n.2, p.1191-197, 1994.

FARIA, C.M.B.de; COSTA, N.D.; PINTO, J.M.; BRITO, L.T. L.; SOARES, J.M. Níveis de nitrogênio por fertirrigação e densidade de plantio na cultura do melão em um Vertissolo. Pesquisa Agropecuária Brasileira, v.35, n.3, p.491-495, 2000.

FERREIRA, F.A.; PEDROSA, J.F. Melão: cultivares e métodos culturais. Informe Agropecuário, v.8, n.85, p.26-28, 1982.

FILGUEIRA, F.A.R. Novo manual de olericultura: agrotecnologia moderna na produção e comercialização de hortaliças. Viçosa: Ed. UFV, 2000. 402p.

FNP CONSULTORIA \& COMÉRCIO. Agrianual 2002: anuário da agricultura brasileira. São Paulo, 2002. p.412-414: Melão.

FURLAN, R. A.; ALVES, D. R. B.; FOLEGATTI, M. V. Dióxido de carbono aplicado via água de irrigação na cultura da alface. Horticultura Brasileira, v.19, n.1, p.25-29, 2001. 
GOMES, T. M. Efeito do $\mathrm{CO}_{2}$ aplicado na água de irrigação e no ambiente sobre a cultura da alface (Lactuca sativa L.). Piracicaba, 2001. 83p. Tese (Doutorado) - Escola Superior de Agricultura "Luiz de Queiroz", Universidade de São Paulo.

GOVINDARAJAN, G.; POOVAIAH, B.W. Effect of root-zone carbon dioxide enrichment on ethylene inhibition of carbon assimilation in potato plants. Plant Physiology, v.55, p.465-469, 1984.

GUALBERTO, R.; RESENDE, F.V.; LOSASSO, P.H.L. Produtividade e qualidade do melão rendilhado em ambiente protegido, em função do espaçamento e sistema de condução. Horticultura Brasileira, v.19, n.3, p.373-376, 2001.

GUSMÃO, S.A.L. de. Interação genótipo $x$ ambiente em híbridos de melão rendilhado (Cucumis melo var. reticulatus Naud.). Jaboticabal, 2001. 143p. Tese (Doutorado) - Universidade Estadual Paulista "Júlio de Mesquita Filho".

HAAG, P.H.; OLIVEIRA, G.D. de; BARBOSA, V.; SILVA NETO, J.M. de. Marcha de absorção dos nutrientes pelo tomateiro (Lycopersicum esculentum Mill) destinado ao processamento industrial. In: HAAG, H.P.; MINAMI, K. Nutrição mineral de hortaliças. Campinas: Fundação Cargill, 1981. p.447474.

HALE, V.Q.; WALLACE, A. Bicarbonate and phosphorus effects on uptake and distribution in soybeans of iron chelated with ethylenediamine di ohydroxyphenyl acetate. Soil Science, v.80, n.5, p.241-245, 1960. 
HANAN, J.J. Greenhouses: advanced technology for protected horticulture. Boca Raton: CRC Press, 1998. 684p.

HARTZ, T.K.; HOLT, D.B. Root-zone carbon dioxide enrichment in field does not improve tomato or cucumber yield. HortScience, v.26, n.11, p.1423, 1991.

HERNÁNDEZ, C.; BUSTOS, V.; ZAMUDIO, N. Fertirrigacion del melon bajo invernadero plastico. Revista Industrial y Agrícola de Tucumán, v.72, n.12, p.1-4, 1995

IBRAHIM, A. Response of plant to irrigation with $\mathrm{CO}_{2}$ enriched water. Acta Horticulturae, n.323, p.205-214, 1992.

KATAYAMA, M. Nutrição e adubação de melão e melancia. In: SIMPÓSIO SOBRE NUTRIÇÃO E ADUBAÇÃO DE HORTALIÇAS, Jaboticabal, 1990. Anais. Piracicaba: Associação Brasileira para Pesquisa da Potassa e do Fosfato, 1993. p.219-226.

KIMBALL, B.A.; MAUNEY, J.R.; RADIN, J.W.; NAKAYAMA, F.S.; IDSO, S.B.; HENDRIX, D.L.; AKEY, D.H.; ALLENS, S.G. Progress research report 039. Phoenix: United States Water Conservation Laboratory, 1986. 125p.

MALAVOLTA, E. Elementos de nutrição mineral de plantas. São Paulo: Agronômica Ceres, 1980. 251p.

MALLICK, M.F.R.; MASUI, M. Origin, distribution and taxonomy of melons. Scientia Horticulturae, v.28, p.251-261, 1986. 
MARSCHNER, $H$. Mineral nutrition of higher plants. 2. ed. London: Academic Press, 1995. 889p.

MARUYAMA, W.I. Condução de melão rendilhado sob cultivo protegido. Jaboticabal, 1999. 42p. Dissertação (Mestrado) - Universidade Estadual Paulista "Júlio de Mesquita Filho".

MARUYAMA, W.I.; BRAZ, L.T.; CECÍLIO FILHO, A.B. Condução de melão rendilhado sob cultivo protegido. Horticultura Brasileira, v.18, n.3, p.175178, 2000.

MAUNEY, J.R.; HENDRIX, D.L. Responses of glasshouse grown cotton to irrigation with carbon dioxide-saturated water. Crop Science, v.28, n.5, p.835-838, 1988.

MENGEL, K.; KIRKBY, E. Principles of plant nutrition. 4.ed. Bern: International Potash Institute, 1987.687p.

MILLER, G.W. Carbon dioxide-bicarbonate absorption, accumulation, effects on various plant metabolic reactions, and possible relations to lime-induced chlorosis. Soil Science, v.80, n.5, p.241-245, 1960.

MOORE, F.D. Potential for irrigation with carbon dioxide. Acta Horticulturae, n.278, p.171-178, 1990.

MORTENSEN, L.M. Review: $\mathrm{CO}_{2}$ enrichment in greenhouses; crops responses. Scientia Horticulture, v.33, n.1, p.1-25, 1987. 
NOVERO, R.; SMITH, D.H.; MOORE, F.D.; SHANAHAN, J.F.; D’ANDRIA, R. Field-grown tomato response to carbonated water application. Agronomy Journal, v.83, p.911-916, 1991.

PAPADOPOULOS, I. Tendências da fertirrigação. In: FOLEGATTI, M.V. (Coord.) Fertirrigação: citrus, flores e hortaliças. Guaíba: Agropecuária, 1999. p. 11155.

PARKER, D.R.; NORVELL, W.A. Advances in solution culture methods for plant mineral nutrition research. Advances in Agronomy, v.65, p. 151-203, 1999.

PEREIRA, C.; MARCHI G. Cultivo comercial em estufas. Guaíba: Agropecuária, 2000. 118p.

PIMENTEL, A.A.M.P. Olericultura no trópico úmido: hortaliças na Amazônia. São Paulo: Ceres, 1985. 322p.

PINTO, J. M. Aplicação de dióxido de carbono via água de irrigação em meloeiro. Piracicaba, 1997. 82p. Tese (Doutorado) - Escola Superior de Agricultura "Luiz de Queiroz", Universidade de São Paulo.

PINTO, J. M.; SOARES, J. M.; PEREIRA, J. R; COSTA, N. D.; BRITO, L. T. L.; FARIA, C. M. B.; MACIEL, J.L. Sistema de cultivo de melão com aplicação de fertilizantes via água de irrigação. Petrolina: EMBRAPACPTASA, 1996. 24 p. (EMBRAPA- CPATSA. Circular Técnica, 36). 
PRABHAKAR, B.S.; SRINIVAS, K.; SHUKLA, V. Yield and quality of muskmelon (cv. Hara madhu) in relation to spacing and fertilization. Progressive Horticulture, v.17, n.1, p.51-55, 1985.

PRETY, K.M. O potássio na qualidade dos produtos agrícolas. In: YAMADA, T. (Ed.). Potassio na agricultura brasileira. Piracicaba: Instituto da Potassa \& Fosfato, 1982. p.177-194.

RAIJ, B. van; CANTARELLA, H.; QUAGGIO, J.A.; FURLANI, A.M.C. Recomendações de adubação e calagem para o Estado de São Paulo. 2.ed. Campinas: Instituto Agronômico \& Fundação IAC, 1996. 285p.

RHOADS, W.A.; WALLACE, A. Possible involvement of dark fixation of $\mathrm{CO}_{2}$ in lime-induced chlorosis. Soil Science, v.80, n.5, p.248-256, 1960.

RINCÓN SÁNCHEZ, L.; SÁEZ SIRONI, J.; PÉREZ CRESPO, J.A.; MADRID, R. Growth and nutrient absorption by muskmelon crop under greenhouse conditions. Acta Horticulture, v.458, n.3, p.153-159, 1998.

RIZZO, A.A.N.; BRAZ, L.T. Características de cultivares de melão rendilhado cultivadas em casa de vegetação. Horticultura Brasileira, v.19, n.3; p.370373, 2001.

ROSTELATO, C. Melão-de-renda é nova opção para estufas. Suplemento Agrícola, n.2187, p.G3, out.1997. 
SARRUGE, J.R.; HAAG, H.P. Análises químicas em plantas. Piracicaba: ESALQ, Departamento de Química, 1974. 56p.

SENTELHAS, P.C. Estimativa diária da evapotranspiração de referência com dados de estação meteorológica convencional e automática. Piracicaba, 1998, 97p. Tese (Doutorado) - Escola Superior de Agricultura "Luiz de Queiroz", Universidade de São Paulo.

SGANZERLA, E. Nova agricultura: fascinante arte de cultivar com os plásticos. Porto Alegre: Petroquímica Triunfo, 1990. 303p.

SILVA, H. R.; MAROUELLI, W.A.; SILVA, W.L.C.; SILVA, R.A.; OLIVEIRA, L.A.; RODRIGUES, A.G.; SOUZA, A.F.; MAENO, P. Cultivo do meloeiro para o norte de Minas Gerais. Brasília: Embrapa Hortaliças, 2000. 22p.(Circular Técnica, 20).

SMITH, D.H.; MOORE, F.D.; NOVERO, R.; SHANAHN, J.F.; D`ANDRIA, R. Field-grown tomato response to carbonated water application. Agronomy Journal, v.83, n.5, p.911-916, 1991.

SOUSA, V. F. de; RODRIGUES, B.R.N.; ATHAYDE SOBRINHO, C.; COELHO, E.F.; VIANA, F.M.P.; SILVA, P.H.S. Cultivo do meloeiro sob fertirrigação por gotejamento no meio norte do Brasil. Teresina: Embrapa Meio-Norte, 1999a. 68p. (Embrapa Meio-Norte. Circular Técnica, 21). 
SOUSA, V.F. de; COELHO, E.F.; BASTOS, E.A.; FOLEGATTI, M.V.; FRIZZONE, J.A. Doses de nitrogênio e potássio por fertirrigação na produtividade do meloeiro. In: BALBUENA, R.H.; BENEZ, S.H.; JORAJURIA, D. Avances en el manejo del suelo y agua en la ingenieria rural latinoamericana. La Plata: Universad Nacional de La Plata, 1998b, p.195200.

SOUSA, V.F. de; SOUSA, A.P. Efeitos da freqüência de aplicação de $\mathrm{N}$ e K por gotejamento na cultura do meloeiro (Cucumis melo L.). Engenharia Agrícola, v.17, n.3, p.36-45, 1998c.

SOUSA, V.F. de; COELHO, E.F. Manejo de fertirrigação em fruteiras. In: FOLEGATTI, M.V. (Coord.) Fertirrigação: flores, frutas e hortaliças. Guaíba: Agropecuária, 2001. v.2, cap.9, p. 289-317.

STOFFELLA, P.J.; LI, Y.; PELOSI, R.R.; HAMNER, A.M. Citrus rootstock and carbon dioxide enriched irrigation influence on seedling emergence, growth, and nutrient content. Journal of Plant Nutrition, v.18, n.7, p.1439-1448, 1995.

STORLIE, C.A.; HECKMAN, J.R. Bell pepper yield response to carbonated irrigation water. Journal of Plant Nutrition, v.19, n.10/11, p.1477-1484, 1996a.

STORLIE, C.A.; HECKMAN, J.R. Soil, plant, and canopy responses to carbonated irrigation water. HortTechnology, v.6, n.2, p.111-124, Apr./June 1996b. 
TYLER, K.B.; LORENZ, O.A. Nutrient absorption and growth of four muskmelon varieties. Journal of the American Society for Horticultural Science, v.84, n.1, p.191-195, 1964.

VILLAS BÔAS, R.L.; ANTUNES, C.L.; BOARETTO, A.E.; SOUSA, V.F.de; DUENHAS, L.H. Perfil da pesquisa e emprego da fertirrigação no Brasil. In: FOLEGATTI, M.V. (Coord.) Fertirrigação: flores, frutas e hortaliças. Guaíba: Agropecuária, 2001. v.2, cap.2, p. 71-103.

VITTI, G.C.; BOARETTO, A. E.; PENTEADO, S.R. Fertilizantes e fertirrigação. In: SIMPÓSIO BRASILEIRO SOBRE FERTILIZANTES FLUÍDOS. 1., Piracicaba, 1993. Anais. Piracicaba: Associação Brasileira para a Pesquisa da Potassa e do Fosfato, 1994. p. 261-280.

VIVANCOS, A. D. Fertirrigación. Madrid: Mundi-Prensa, 1993. 217p.

ZAPATA NICOLAS, M.; CABRERA FERNÁNDEZ, P.; BAÑON ARIAS, S.; ROTH MARTINEZ, P. EI melon. Madrid: Mundi-Prensa, 1989. 174p. 